\title{
The press coverage of the August 2012 Marikana Shootings
}

$$
\text { by }
$$

Clive Emdon

\begin{abstract}
A thesis submitted to the Faculty of Graduate and Postdoctoral Affairs in partial fulfillment of the requirements for the degree of
\end{abstract}

\author{
Master of Journalism
}

JOUR 5909

\author{
Carleton University \\ Ottawa, Ontario
}

(C) 2015. 


\begin{abstract}
In August 2012 the South African police shot and killed 34 striking miners, and injured 78 at the Lonmin platinum mine at Marikana. This news event was such that it had the potential to force a change in government, as well as to impact labour employment and production in the mining industry. As a complex event, Marikana was chosen to analyse the press at work. This thesis has focused on four main narratives from the media coverage: firstly, the economic narrative; secondly, the narrative about the carrying of tribal weapons and practices used by the striking miners; thirdly, the accounts of the shootings; and fourthly, the fall-out within the unions. The main findings reflect a lack of in-depth reporting and analysis of the mining economy and its labour; and the failure of the press to adequately narrate the impact of the police shootings on the three partners in government.
\end{abstract}




\section{Acronyms}

AMCU Association of Mineworkers and Construction Union

ANC African Nation al Congress

BRICS Nations: Brazil, Russia, India, China and South Africa

CCMA Government Commission for Conciliation, Mediation and Arbitration

Cosatu Congress of South African Trade Unions

Fedusa Federation of Unions of SA

GEAR Growth, Employment and Reconstruction

GCIS Government Communication and Information System

Nactu National Council of Trade Unions

NPA National Prosecuting Authority

NUM National Union of Mineworkers

Numsa National Union of Metalworkers of South Africa

RDO Rock-drill operator

RDP Reconstruction and Development Programm

SABC South African Broadcasting Corporation

SACP South African Communist Party

SAPA South African Press Association

SAPS South African Police Services 


\section{TABLE OF CONTENTS}

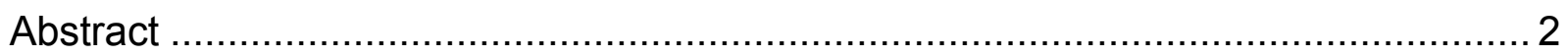

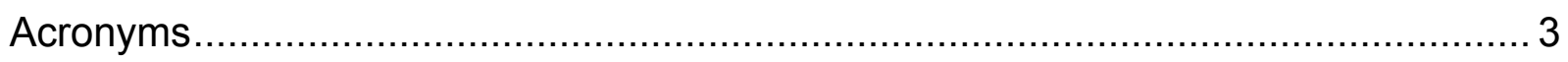

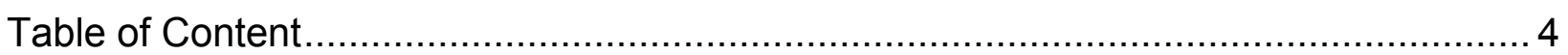

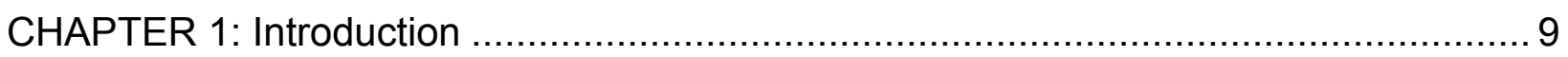

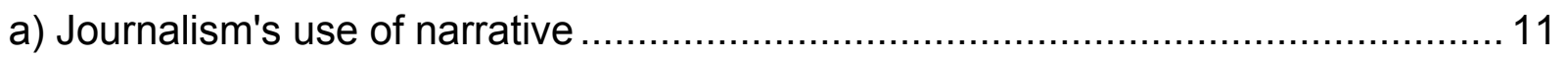

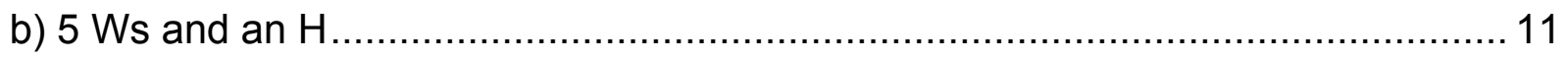

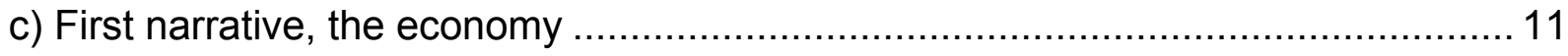

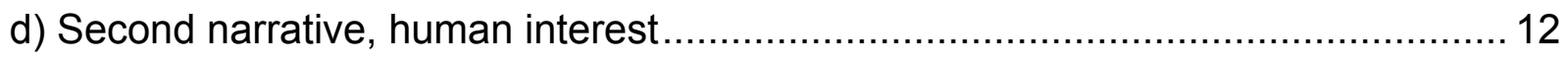

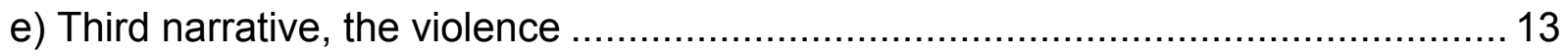

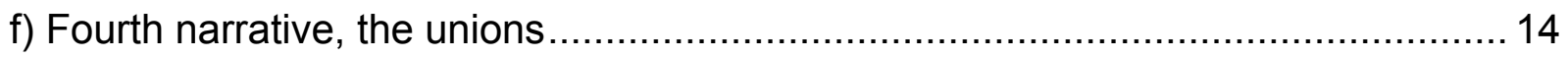

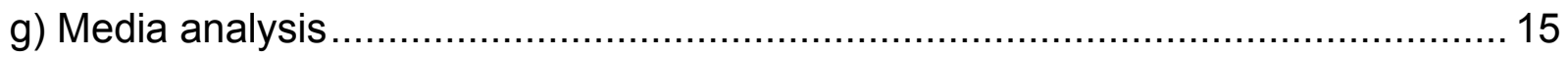

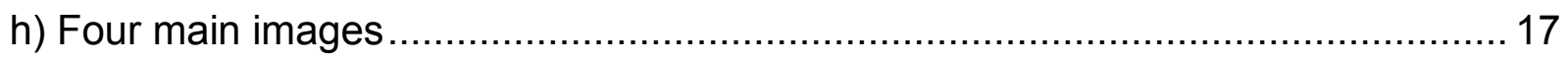

i) Photograph 1: from Miners Shot Down ...................................................... 17

ii) Photograph 2: Striking miners brandish their weapons on the day 34 were shot and killed by the police .................................................................................. 17

iii) Photograph 3: Book Cover of "We are going to kill each other today: The Markikana Story" by Jika, T et al .................................................................... 18

vi) Photograph 4. Shootings as seen from behind the police lines ...................... 18

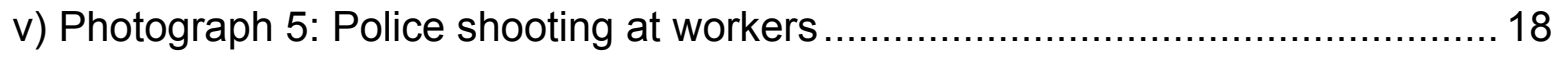

vi) Photograph 6: Heavily armed police pointing guns at dying strikers ................ 19 
vii) Photograph 7: Police stand over the bodies of dead and dying miners

e) Timeline 19

CHAPTER 2: Platinum Mining and the Economy - the Challenges of Transformation 23

a) The platinum industry . 24

b) Migrant Labour 27

c) Peri-urban poverty and poor housing 29

d) Loss of bargaining power 36

e) Slow transformation of the mining sector 40 Conclusion

CHAPTER 3 : The Strikers, and their Weapons and 'Muti' Culture 45

a) The transformation of the rural man to an urban mine worker: the narrative of Mambush.

b) The culture of carrying tribal weapons. 51

c) Secret rituals of the medicine man. 56

d) The cleansing ceremony 58

Conclusion 59

CHAPTER 4: The violent build-up to "D-Day" . 60

a) Brutality, fear and revenge 62

(viii) Photograph 8: Anti-mine armoured vehicles used by Police at Marikana....... 63

b) Lonmin's role ..... 65

c) Internecine battle between NUM and AMCU. 67 
d) Collusion between government, Lonmin and the police.

ix) Photograph 9: Strikers armed with traditional weaponse) The build-up to the shootings.

x) Photograph 10: Mambush leading the strikers carrying pangas ....................... 71

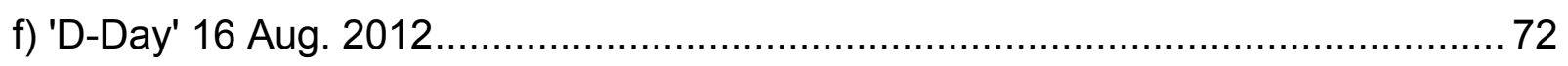

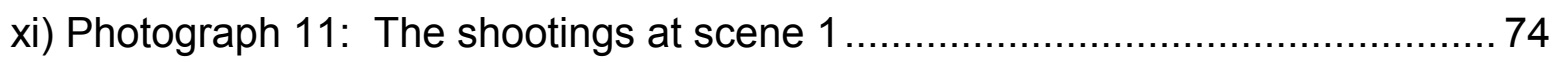

xii) Photograph 12: Police weapons drawn over dying bodies ........................... 74

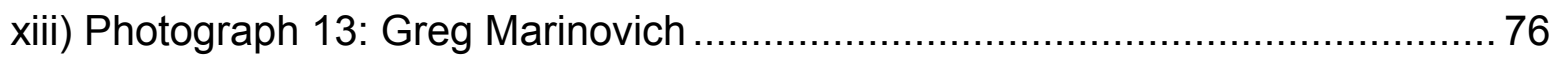

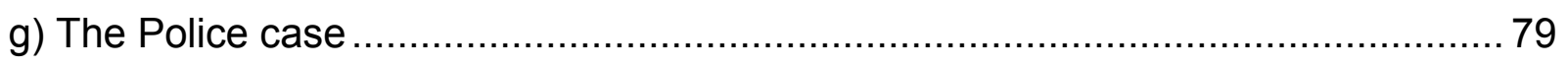

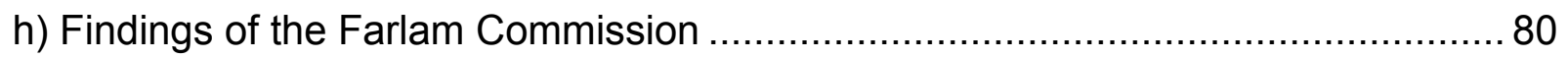

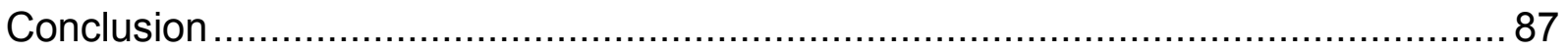

CHAPTER 5: MARIKANA AND THE NEW POLITICS OF LABOUR ............................ 89

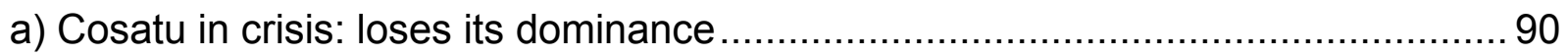

b) The rise of the Black middle class and the dynamics of labour .......................... 92

d) 'Numsa's Moment' -- the break with the ANC and other fall-out .......................... 94

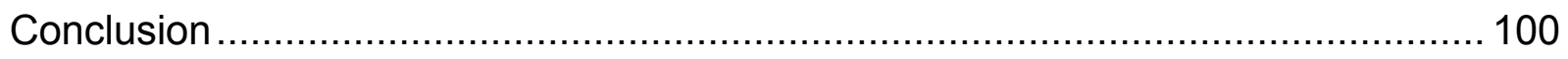

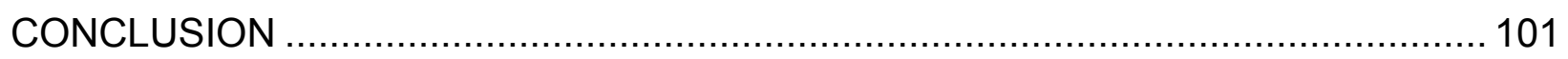

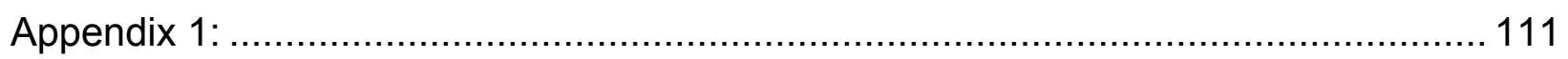

The Star Front Page on 17 August 2012 .................................................. 111

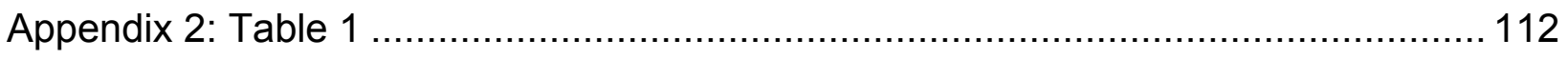


Average Salaries of Miners - Source, International Labour Organisation and the Human Sciences Research Council, Johannesburg+

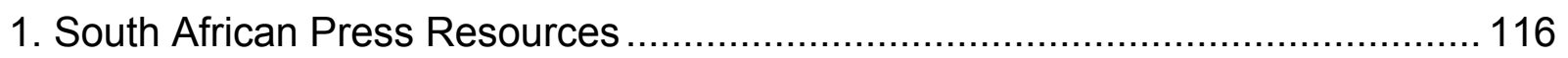

SABC (South African Broadcasting Corporation) ............................................ 116

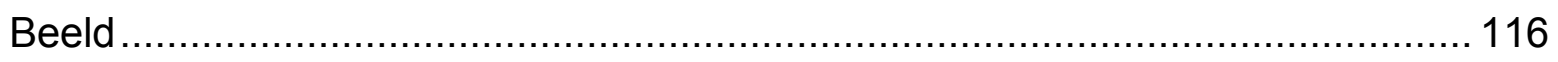

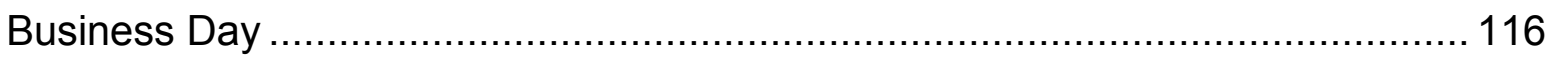

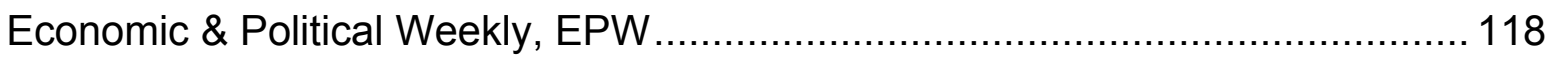

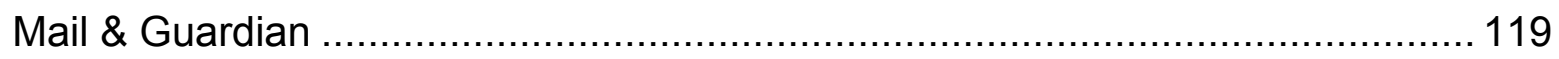

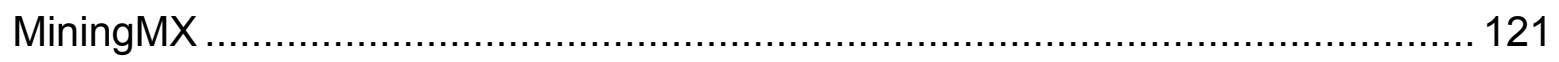

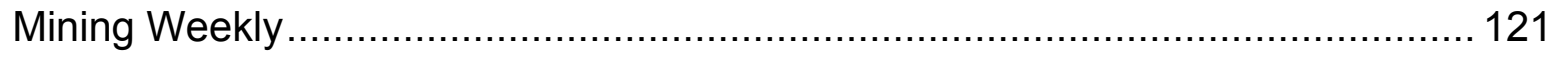

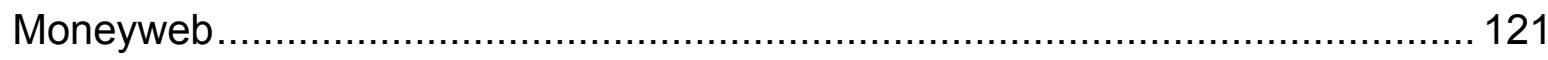

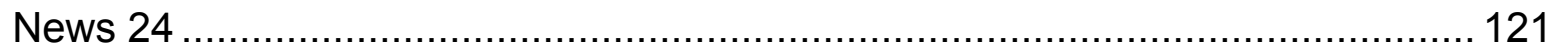

SABC (South African Broadcasting Corporation) .......................................... 121

SAPA (South African Press Association) ………...................................... 122

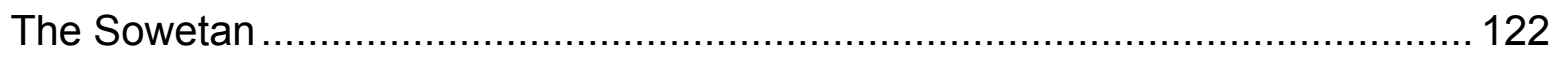

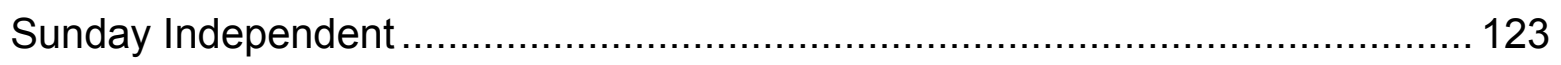

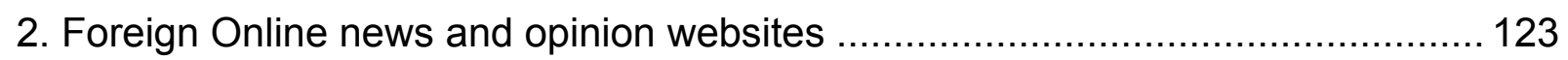

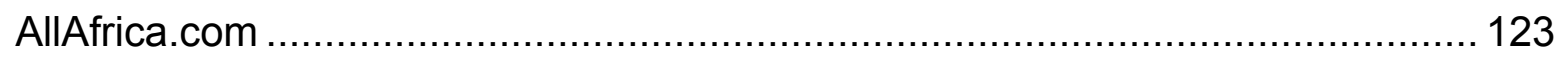

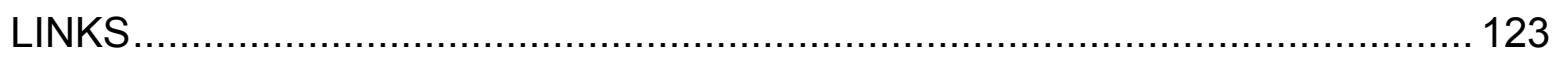

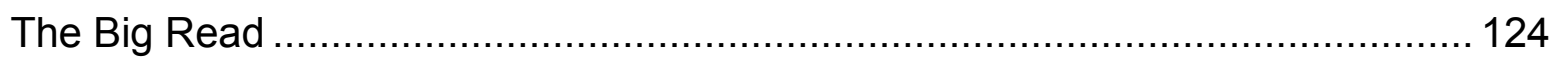


THE BULLET

AlJazeera

Channel 4 News,

Gilmore, Inigo, (2013)." Marikana survivors 'harassed' ahead of trial", 29 Jan. 2013. http://www.channel4.com/news/marikana-zuma-to-publish-south-african-massacrereport.

eNCA,

YouTube

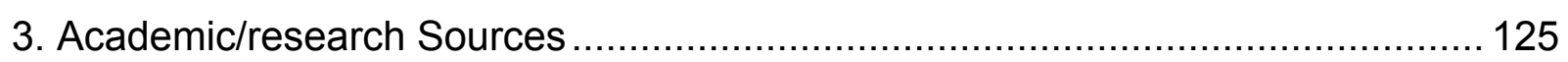

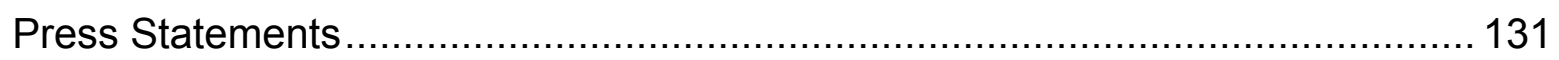

Full list and biographies of all the striking workers killed on 13 and 16, Aug. 2012 


\section{CHAPTER 1: INTRODUCTION}

The shootings took place during a strike by workers in a platinum mine owned by British multinational mining company Lonmin PLC. The workers were engaged in an unprotected strike ${ }^{1}$ because they felt let down by the formal bargaining system. They were demanding a monthly salary increase to 12,500 Rand (US\$1,500) from a rate of R4 160 (US\$500). Lonmin maintained that this demand was unreasonable and would impact negatively on the company's viability. Academic commentaries have characterised the Marikana shootings of the workers by the police as 'a massacre' similar to the Sharpeville shootings in March 1960, when the apartheid police shot and killed 69 protestors against the pass laws ${ }^{2}$, and wounded 180 others. This was described as a decisive historical moment triggering armed resistance to apartheid South Africa and the world's condemnation.

This thesis examines the press narrative of the Marikana strike and the workers' grievances, the trade union differences, and the reported crisis within the labour federation, the Congress of South African Trade Unions (Cosatu) as a result of the shooting. For many, the shooting was seen symbolically as a betrayal of the working class. Except for a small group of key newspapers ${ }^{3}$ the media at large fails to penetrate and reflect the main labour issues that prompted the strike nor did it focus on the outcome of the shootings for Cosatu as the third partner in the African National Congress (ANC) government, or for the ANC itself.

In searching for sources of information and making choices about how this thesis would best reflect the Marikana story as reported in the media I selected the newspapers in the national press that were most consistent in the reporting of Marikana. They were the few newspapers that not only made their journalists available to cover Marikana despite the expense of travel and time, and continued to follow through three years after the police shootings.

The findings of the Farlam Commission of Inquiry ${ }^{4}$ produced some definitive conclusions as to the gaps in the information contained in the press reports. 
As the Farlam Commission concluded while the thesis was being written, it has been able to extend the narrative to include the major findings from the Commission.

As a seasoned journalist living in Canada during the unfolding of the Marikana story, my sources came mainly from news coverage that is available online. A turning point in following the story came when the documentary film on Marikana Workers Shot Down ${ }^{5}$ by South African film maker Rehad Desai ${ }^{6}$ was shown at Carleton University by the Institute of African Studies and disseminated in Canada (but it was not yet available online) and has to date (December 2015) not yet been aired on national television in South Africa. This film was first made available internationally in March 2014. Miners Shot Down ${ }^{7}$ shows in graphic detail the massacre of dozens of miners at Marikana as captured by police footage. It was aired 18 months after the police shootings by $\mathrm{Al}$ Jazeera, Reuters, YouTube and others. After seeing the documentary I felt obliged to discover why the South African press had failed to reflect the detailed description of the shootings and the deaths of the workers. This documentary film raises a multitude of issues, many of which were taken up in the Farlam Commission of Inquiry. One such issue was the police claim that they began shooting when attacked by striking workers. This was disproved by the film.

The main news on Marikana came from a small handful of journalists working for mainstream city newspapers or for online newspapers and blogs. At the time of submitting this thesis (January 19, 2016) the film Miners Shot Down had not been broadcast on any public television network in South Africa, however, community groups and organization have screened it to interested audiences.

Research for the thesis sourced 80 South African press reports online and 45 foreign media reports (mostly newspapers) as well as 28 South African online newspapers and blogs and seven foreign blogs. ${ }^{8}$ The South African newspapers that reported Marikana consistently (see End Note 3) published some of the best sourced information. In addition this thesis consulted 60 academic sources on Marikana. 


\section{a) Journalism's use of narrative}

These sources were organised around four themes in the narrative of Marikana. Drawing on the concept of narrative developed by sociologist Catherine Kohler Riessman (1993), this thesis is a descriptive approach to the events and aftermath of the events at Marikana. Kohler Riessman suggests that journalism makes use of narrative because "the story metaphor emphasises that we create order, construct texts in particular contexts...Narrative analysis takes as its object of investigation the story itself." (Kohler Riessman 1993, p. 1). She quotes Burke's (1945) classic method of analysing language in which she says 'dramatism' offers "a structural approach that has potential application to a variety of types of narrative, including stories. The grammatical resources that individuals employ to tell persuasive tales are contained in a pentad of terms: act, scene, agent, agency, purpose."

Any complete statement about motives will offer some kind of answer to these five questions: What was done (act), when or where it was done (scene), who did it (agent), how he [or she] did it (agency), and why (purpose). (Burke, 1945, p. xv as in Riessman Kohler).

\section{b) $5 \mathrm{Ws}$ and an $\mathrm{H}$}

The key to my own schooling in journalism was the $5 \mathrm{Ws} \&$ an $\mathrm{H}$, namely Who was involved? What happened? When did it happen? Where did it happen? Why did it happen? and How did it happen? This was the method taught generally as the basis of narrative in journalism, which is what is used to understand the reporting of Marikana. This therefore is an interpretation of the journalism (other interpretations) and is not a judgement of newsroom practice. However, the conclusions I reach in this research reflect on gaps in the practice of journalism, in particular of the newsrooms in South Africa.

\section{c) First narrative, the economy}

In the development of the Marikana story, four narratives that relate to the South African identity (Zeitgeist) emerge and are reflected in this thesis. The identity of the new South 
Africa is in the making 20 years after the end of apartheid, and Marikana brings many of the contradictory elements to the fore. The first narrative revolves around South Africa's resources and wealth. Black Economic Empowerment policies have ensured government politicians wield enormous influence in industry, particularly in the mining sector. Stories on the mining industry enjoy headline news in street posters day after day. Financial and business writers have the highest status amongst journalists, and the business dailies are the most pervasive press in the cities. Other authoritative voices on the Marikana story are the foreign press, particularly The Guardian and the Financial Times of London, which unpack the financial and the socio-economic aspects of the foundations of South Africa. This Marikana narrative evolves about the economy and the international market that platinum demands, the value chain with the global motor industry that consumes platinum for the making of catalytic converters, and the business decisions that were taken with regards to engaging with the workers over their strike demands and of Lonmin's failings as an employer of 26000 mining workers in five different mines.

\section{d) Second narrative, human interest}

The second narrative unpacks the human interest aspects and draws on a more qualitative and emotional understanding of South African society, engrained with empathy but also prejudice. This narrative focuses on the miners' lives, their origins in rural tribalism, and their culture of carrying weapons and the use of the medicine man who gives them muti saying it will protect them against their enemies. At Marikana, part of the police justification of their shooting of striking miners was the strikers' reluctance to put down their traditional weapons of spears and pangas. Media reports failed to reflect the academic research on the contentious issue of trade union workers bearing traditional weapons. This study will examine photographs taken by Greg Marinovich of the striking miners brandishing their 'cultural weapons' and reflect the work in this field by history lecturer Mkhize (2014), ${ }^{9}$ that suggests tribal workers carry weapons, not necessarily to threaten the police, but to signify their social standing and manhood. (Business Day, 26 Aug. 2014). On the day after the shooting Marinovich wrote a 
definitive report published in the online newspaper the Daily Maverick. ${ }^{10} \mathrm{He}$ describes several thousand men wrapped in blankets sitting on a rocky hill "their spears and fighting sticks protruding menacingly as they chant songs of war." The striking rock driller operators were determined to be heard adding "but it's more than a strike, it's becoming a war." Three pictures taken by Marinovich and used in his report show men also brandishing pangas and knives, the very stuff that the police wanted to remove but were not able to do so.

\section{e) Third narrative, the violence}

South Africans live with violence and crime and so the third narrative draws on the underlying anger and fear that ultimately results in revenge and the mass shootings by the police. This third narrative evolves from the brutal murders of two policemen and two Lonmin guards that took place in the week before the mass shootings on August 16, 2012 when 112 men were shot and 34 killed in two different scenarios. Violence and loss of life often accompany strikes in South Africa and the narrative that emerges from these reports include the developing violence and the internecine fighting between two competing unions for members, and the shooting of two workers by union officials of one of the unions by the other.

Media reports and pictures will be compared to the events in the live footage of the documentary film Miners Shot Down. In their descriptions of the shootings, two journalists, Marinovich, and Sacks, and the British human rights lawyer Nichol, agree with academics, Alexander and Gentle that the ANC government sided with the mine owners against the workers' strike action at the Lonmin mine in Marikana. Together they called on the police to act against the workers. The police then carried out a premeditated massacre at Marikana.

This is borne out by reports of the police preparations for August 16, of the arrival of 1,500 policemen with assault rifles, shotguns, and 4000 rounds of ammunition, as well as barbed wire, armored vehicles and four mortuary vans. (Gentle, 2015, Part 1; Sachs, 2014). 
Lonmin provided crucial logistical support for the police that included offices for a "Joint Operation Centre"; intelligence collected by its security personnel; access to more than 200 security cameras; accommodation, food and transport for the police. Lonmin also paid for the helicopters used on the day, and provided ambulances and a detention center (Alexander, 2013). A senior Lonmin executive was part of the police-mine management team. Two Lonmin operators constantly monitored the police radio traffic. Lonmin provided all the television technical CCTV operations and briefed the police once or twice a day. (Nicol, 2014).

Also parts of the narrative of the police shootings was the arrest by the police of 270 strikers many of whom were charged with murder, in an attempt to deflect the responsibility for the shootings, and to hold the strikers responsible for the deaths of their fellow strikers. Nothing came of these cases, and numbers of workers claimed they were tortured by the police while in custody.

\section{f) Fourth narrative, the unions}

The fourth narrative of Marikana centres on worker struggles and the unions that represent a militant articulation of the South African character. Through Marikana emerges a lens on the conflict brewing in the dominant Congress of South African Trade Unions (Cosatu) as it slowly lost its influence because of the swell of a new socialist base and critique of government. The unions were pivotal in the struggle against apartheid and enabled the organisation of mass movements that led to a democratic new South Africa because of their militancy and representativeness of the working class. However, in the Marikana context there was a fallout between the workers and their main union which refused to take up the issue of their strike. What emerged was an opposition union which has its roots in a more radical position. This fourth narrative evolved from the discourse in the labour movement that occurred at Marikana when the dominant National Union of Mineworkers (NUM) under the Cosatu umbrella refused to represent the rock drillers and the new opportunistic movement, Amalgamated Mining and Construction Union (AMCU), stepped into the gap. On August 14, two days in advance of the mass shooting, NUM union officials fired on strikers filing 
past its office. This thesis will examine how well the press coverage reflected the strike and the workers' grievances, the trade union differences, and the reported crisis within the labour federation, Cosatu, as a result of the shootings.

\section{g) Media analysis}

Media academics Jane Duncan (2013) and Benjamin Fogel (2012) stress that two elements of good reporting were missing from the South African press at the time of the Marikana strike and shootings. There was a failure to use eyewitness accounts and interviews with strikers. And It was "apparent that the coverage was heavily biased towards official accounts of the massacre, and that it overwhelmingly favoured business sources of news and analysis" (Duncan, 2013). Furthermore, "the failure of journalists to speak to miners (even as eye-witnesses) sufficiently led to a major editorial failure in the early press coverage" in that "it failed to reveal the full extent of police violence against the miners." As a result, the police version of events remained unchallenged until a group of academics interviewed the miners. The coverage also contained dominant themes which portrayed the miners as "inherently violent, disposed to irrationality and even criminality." Fogel also found that the main journalistic reports were derived from interviews with elites such as economists and mine owners, thus repressing information that would reveal the unfolding events that led to the shooting (Fogel, 2012). Much later, Daily Maverick blogger and photographer Marinovich, who researched the scene for days after the shootings, indicated the official story was "an utter distortion of what actually occurred, despite the large presence of journalists at the scene of the massacre" (Marinovich, 2015). As a result of this, it took more than two years for the details of the shootings in Scene 2 to become known.

For the academics who conducted in-depth research immediately after the shootings that included using students to interview the strikers involved, there has been a growing consensus that Marikana became the fulcrum of the class struggle in South Africa and a defining moment in the relationship between the Alliance partners in government. The shootings led to the waning of Cosatu, the leading trade union federation, as well as the loss of intellectual leadership by the SA Communist as the ANC's power base -- a 
combination that could cost the ANC its commanding position. Researchers Alexander (2012), Legassick (2012), Gentle (2014), Ashman and Pons-Vignon (2015), find that for the ANC, Marikana was a key turning point away from its support of the working class and the labour movement. Few of the media have reflected their writings. These academic researchers assert that Marikana 20 years after the ANC took power in 1994 would prove to be as decisive a moment as the Sharpeville shootings in March 1960, and in time could even result in the fall of the African National Congress (ANC) government, as the working class appropriate new unions, and commit to immediate change through socialist policies and practices.

What was evident, despite the missing interviews with eyewitnesses to the events of Marikana, is the high reporting standards of the newspapers that delivered consistent reporting on Marikana and the work of the photographers and photo-journalists who produced the hundreds of photographs that reflect events and tell the narrative on the Rooi Koppies where the strikers gathered, and of the police shootings. The Star, which is the main Johannesburg afternoon newspaper, published a remarkable front page (see Appendix 1) the day after the shootings (17 Aug. 2012), but this paper is in circulation and the electronic format is behind a paywall, and IOL, the Independent Newspapers group online platform syndicates reports but not the format of the published pages. The Daily Maverick an online newspaper, the Mail \& Guardian, which is a weekly newspaper in South Africa but has large online following of its electronic newspaper, City Press and Business Day also reflected the best possibilities in newspaper journalism. ${ }^{11}$ The visuals remain a valuable part of the press narrative of Marikana, as was shown particularly by Greg Marinovich, Alon Skuy, Siphiwe Sibeko and Phill Magakoe, as well as the documentary film Miners Shot Down by Rehad Desai.

Questions remain about the decisions that were taken in newsrooms on how best to cover the events of Marikana. There is a clear lack of in-depth and investigative reporting, partly due to the failure of maintaining specialist writers and beat reporters. Marikana was complex, but had the strike been reported on properly, the tragedy of the 
shootings, the fall of the platinum industry and the breakdown of labour and the confusion in the trade unions may have been averted. The failure that remains is that the ANC government and its alliance partners have yet to be held accountable for what happened at Marikana and are still to receive the wrap.

\title{
h) Four main images
}

\section{i) Photograph 1: from Miners Shot Down}

\author{
Photograph 1 \\ http://www.gettyimages.ca/detail/news-photo/people-gather-on-a-hill-in-marikana-on- \\ august-23-2012-after-news-photo/150629158 \\ The photographs of the meetings of the estimated 3,000 striking rock drillers covering \\ the main red hills or 'Rooi Koppies' on the outskirts of the informal settlement of \\ Nkaneng near the Karee mine, one of three Lonmin platinum mines where the strike \\ and shootings took place. (Photograph from Getty Images captured online by \\ Ceasefire magazine published by Usayd Younis published in Ceasefire )
}

There are four main images that were repeated in the press but yet did not give the full story, although they make an important contribution to the narrative. They are of the mass of strikers sitting on the Rooi Koppies; the carrying of traditional weapons by the miners; the story of the strike leader, Mambush, and the shooting of the striking workers by the police. These visuals are as much part of the main narrative as any of the writings of the press and inform one of the progress of the events.

\section{ii) Photograph 2: Striking miners brandish their weapons on the day 34 were shot and killed by the police}




\title{
Photograph 2:
}

http://www.poyi.org/70/11/first 03.php

An angry group of striking miners wielding carrying 'traditional weapons:' sticks, knobkerries, spears, inculas (metal spokes) knives and axes, and controversially, pangas (machetes) Picture by Alon Skuy (The Times)

\section{iii) Photograph 3: Book Cover of "We are going to kill each other today: The Markikana Story" by Jika, T et al}

\author{
Photograph 3 \\ http://www.nb.co.za/Books/15820 \\ Caption The narrative that focuses on Mgcineni Noki (40), known as 'Mambush' - \\ the strike leader, (on the right) who was from Twalikhulu in the Eastern Cape. He \\ worked for Lonmin from 2009 and was a leader of the strike, and was shot down by \\ the police on 16 Aug. 2012; \\ (Photograph by Gallo Images for Getty Images)
}

vi) Photograph 4. Shootings as seen from behind the police lines

Photograph 4

http://www.poyi.org/70/11/first 07.php

Fourthly the shooting as seen by photographers behind the police lines.

(Photograph by Alon Skuy in The Times).

\section{v) Photograph 5: Police shooting at workers}



Photograph 5
Police shootings at Marikana
http://www.reuters.com/article/us-safrica-lonmin-bodies-idUSBRE87F0QC20120816 from VIDEO
Caption: South African police shoot dead striking miners. August 16, 2012
(by John Mkhize for Reuters)

\section{vi) Photograph 6: Heavily armed police pointing guns at dying strikers}

Photographs 6

FORCE: Police stand guard over mine workers, who had been shot near the Nkaneng informal settlement on August 162012.

Picture: ALON SKUY in BDlive (Business Day)..

http://www.bdlive.co.za/national/2014/09/05/video-contradicts-police-shows-strikers-

\section{vii) Photograph 7: Police stand over the bodies of dead and dying miners}

\section{Photograph 7}

Caption: And the images of heavily armed police still pointing their guns at the dead and dying as they stroll between the bodies after the first shooting.

(Photograph by Alon Skuy, The Times, Johannesburg)

http://www.timeslive.co.za/local/2013/11/26/miners-shot-some-marikana-victims-cop

\section{e) Timeline}

The events, issues, and stakeholders that lead to Marikana are complex and therefore the division of the chapters is done according to the various narratives that emerged, but the chronology runs through these narratives. As a starting point to assist the reader to navigate the chronology, a timeline of events is included here. Throughout the chapters on the narratives, and in the concluding chapter this thesis seeks to answer 
the question of how well the press reflected the events of Marikana, which were a turning point in South Africa's post-apartheid history.

Events leading to the shootings:

- On Wednesday August 8, rock drill operators (RDOs) from various Lonmin mines had a mass meeting demanding a significant salary increase. NUM leaders present categorically refused to support the strike despite a large majority of the workers at the assembly were NUM members, AMCU was unrepresented at this meeting.

- On the morning of Friday the 10th, workers assembled and marched to the offices of Lonmin management. The Lonmin management refused to speak to the workers, who were assembled peacefully, and told them to go back to the NUM leadership. Violence erupts at Lonmin's Marikana mine sparked by a protest by 3,000 rock-drill operators over wages. It continues over the weekend and into Monday, claiming the lives of at least eight Lonmin workers and two policemen.

- On Saturday August 11, workers, still primarily RDOs, decided to go to the main offices of NUM in Wonderkop and present union leadership with a memorandum. It is important to note that the NUM offices are also the offices of the ANC and SACP in Wonderkop. They are manned by the top five NUM branch leaders from all the Lonmin mines in Marikana. These leaders are senior to shop-stewards and are elected to their position by workers for a period of three years. As strikers were by and large NUM members, they were naturally angry that their own union refused to listen to them. The memorandum demanded that NUM represent them in their call for a R12,500 minimum wage for all miners. As a result of Lonmin and NUM's refusal to meet with the workers, more than 3,000 Rock Drill Operators (RDOs) and other miners decided to go on strike and refused to clock in that evening. This was a wildcat strike organised directly by workers, without any union representation

- Saturday August 11, cont. As strikers were by and large NUM members, they were angry that their own union refused to listen to them. "Only a handful of AMCU members were present during that march, as many workers from the Karee mine, where AMCU already had a membership presence, was far away and not yet participating in significant numbers in the strike. Xolani, one of the few AMCU members present that day, said this protest was really a case of NUM members rebelling against their own leadership, not a case of inter-union rivalry. He said once 
the striking RDOs were about 100-150 metres away from the NUM office, the "top five" NUM leaders and other shop stewards, between 15 and 20 in all, came out of the office and began shooting at the protesting strikers somewhere in the vicinity of the Wonderkop taxi rank.

- The strikers and other witnesses claimed that the NUM personnel shot at the protesters without warning or provocation. The miners were clearly ambushed by their union representatives. They later re-assembled at Lonmin's football stadium, deciding there for the sake of safety to move to the nearby koppie, a small hilltop uniquely placed on public land between Wonderkop, Marikana and the various Lonmin mines. John, a non-striking Lonmin worker, saw two bodies of strikers not far from the NUM office as he returned home from work. One was lying dead by the bus stop in the taxi rank, the other was just outside the workers' hostel.

- Within four days, the striking mine workers brutally hacked to death 10 people including two policemen, and two Lonmin security staff, a NUM official and workers refusing to strike. Among those killed was a senior mine supervisor whose body was found on a footpath. A cow's skull was left on his chest.

- On Tuesday August 14 Lonmin halts production.

- On Wednesday August 15 Mineral Resources Minister Susan Shabangu says she was "gravely concerned" about the violent protests at Marikana. Advocate Ishmael Semenya representing the South African Police Service said police evidence would show that some protesters had wanted a "bloodbath", and that police had set out to perform to the best of their abilities in a difficult situation.

- Police and striking miners later tried to negotiate a truce on a hill near the Lonmin mine where striking miners had gathered. It was reported that Lonmin refrained from issuing letters to striking workers warning of dismissals in order to avoid "harming" the ongoing negotiations.

- On Thursday 16 August six people were arrested following violent protests at Lonmin's mine. Police officials then ordered thousands of striking miners to leave Marikana mine or face an assault by security forces. "Today is unfortunately D-day," police spokesman Dennis Adriao says. The police preparations for that day included the arrival of 1,500 policemen with automatic weapons and shotguns, 4000 rounds of ammunition, and four mortuary vans They laid razor/barbed wire fences and positioned their vehicles close to the Rooikoppies where the workers had gathered. 
- On August 16 according to witnesses some workers had walked down to the razor wire to see if they could still get out through a gap. Police near the "small koppie" (hillock) opened fire on them, possibly with rubber bullets. Some workers fled through a five metre gap in the razor wire. They were met with a barrage of live fire from the police and many died. Images of this shooting were broadcast around the world. This was described as 'Scene' 1 where 17 miners were killed and many injured, Those that escaped that shooting ran through a rocky area where 17 more workers were killed in what is described as 'Scene 2'. In all 112 miners were shot, 34 were killed and 78 injured. Earlier the same day, August 16, Lonmin reported that it has lost six days or 15000 ounces of platinum at Marikana and was unlikely to meet its full-year production target of 750000 ounces despite issuing striking workers with an ultimatum that they return to work by Friday (the next day) or face dismissal. Lonmin's chief executive, lan Farmer, was admitted to hospital with a serious illness

- 30 August 2012 Authorities charge the 270 arrested workers with the murder of their colleagues shot on 16 August. The charges are later withdrawn. (eNCA)

- 18 September 2012 Workers at Marikana secure pay increases of between $11 \%$ and $22 \%$, and agree to end the strike. (eNCA)

- 1 October 2012 The Marikana Commission of Inquiry opens in Rustenburg.

- 31 March 2015 The Farlam Commission report is submitted to President Jacob Zuma

- 25 June 2015 First information about the report issued on Television and Radio by President Jacob Zuma

- 26 June 2015 The Farlam Commission Report becomes available to the media. 


\section{CHAPTER 2: PLATINUM MINING AND THE ECONOMY - THE CHALLENGES OF TRANSFORMATION}

Marikana, known in Afrikaans as Rooikoppies (Red Hills), is at the heart of the platinum industry in South Africa. It contributes more to the nation's GDP than gold and diamonds combined. ${ }^{12}$ It is established that $90 \%$ of global platinum reserves lie in a narrow stretch of rock in the earth's crust known as the Bushveld Igneous Complex, north east of Pretoria. (Shenker, 2014, The Guardian, 15 Aug.) The industry employs some 195000 workers mainly from two South African provinces: Eastern Cape, and KwaZulu-Natal, and from two neighbouring countries: Lesotho and Mozambique. Through the media coverage of the mining sector, the economic factors in the Marikana story focused on the challenges of transformation in the mining sector. This chapter will explore the media narrative that emerged in the Marikana story that focus on: a) the platinum industry that is dependent on the leads and lags of global demand while it depends on cheap labour. This brings to the fore the extreme inequality between mine owners, shareholders and workers which became a theme of the Marikana miners' discontent. b) The slow transformation of the migrant labour system as the key method of recruiting cheap labour to the mining industry under apartheid, to its gradual replacement by differing forms of migrant labour. c) The exploitation of workers living in rural and peri-urban poverty, and the failure to provide adequate housing and services. d) Rising unemployment with jobs becoming less secure and temporary contracts undermining permanent employment in the mines. There was a loss of bargaining power as the NUM lost ground with workers facing job insecurity and poor pay levels. Amidst these conditions the striking workers agreed to a Lonmin deal. e) Change in the mining sector is too slow. By August 2015 the whole sector was preparing for largescale layoffs.

Marikana started as breaking news in the financial media because of the strike action affecting the lucrative platinum commodity sector. The economic narrative of the troubled mining houses listed on the London and New York stock exchanges, as seen by the largest international audience and told by the foreign media at large in South 
Africa, provides the more comprehensive economic stories involving commodities. The South Africa media focusing on Marikana in the early days of the strike were led by economics and financial writers, who have the highest prestige in the media. They focus on investment interests and the markets with less emphasis on labour issues or the interests of poor, semi-rural populations such as those in Marikana. The Marikana events immediately attracted the attention of a few prominent South African-based academics who were out in the field directly after the police shootings, and whose writings were published adding to the depth of economic and social discourse, in particular, the writing of Peter Alexander and Leonard Gentle. These are the sources that inform this economic narrative.

\section{a) The platinum industry}

The platinum sector in South Africa is one of the most lucrative industries in the world ${ }^{13}$ and at the same time provides an example of disparities and inequalities in the way that wealth is distributed. It provides exceptional gains for shareholders and foreign investors, including key ANC leaders who are shareholders and mining executives as a result of the Black Economic Empowerment policies of reconstruction after apartheid. But for the workers who mine this important resource, it remains a hazardous engagement providing poor working conditions, pay levels and living facilities. The multinational mining houses in South Africa are governed by executives and boards of the new black elite -- mine owners and high ranking members of the government, many of whom were previously trade unionists, such as Kgalema Motlanthe, who served as President of South Africa for eight months in 2008-2009 and the current Deputy President of the ANC, Cyril Ramaphosa. According to experts, mining workers in South Africa are the lowest paid miners in the world (Gentle, 2014) $)^{14}$. The incomes of shareholders, mine owners and their staff stands in stark contrast to the dehumanising living and working conditions of underground workers. This tension is extreme in the platinum industry and surfaces as the media examined the supply of workers, their recruitment, working and living conditions that led to the perfect storm at Marikana. 
The government wants to have control over the mining sector, and the ANC rhetoric in the Freedom Charter has always been for nationalisation of the mines. However, policies in this regard have been softened and changed to new demands that the mining sector retain jobs rather than cut them as a result of global market changes. This "safety policy" was challenged historically by Cosatu and unionists on the left, and would continue to be challenged.

Addressing the miners at Lonmin the day after the shootings, former ANC Youth League leader Julius Malema called for nationalisation of the mines while driving a socialist programme, a position that enjoyed wide support from the striking miners. (Sowetan, 18 Aug. 2012) Aubrey Matshiqi, a research fellow at the Helen Suzman Foundation, said: "I think the people of Marikana, particularly the miners, see themselves as the manifestation of the gap between mineral wealth and socioeconomic conditions. The death of so many miners has amplified the extent to which Julius Malema's views on mine nationalisation resonate with the people in the area." (Sowetan, 18 Aug. 2012 \& The Guardian, 18 Aug. 2012). The ANC had rejected the issue of wholesale nationalisation at its mid-year conference and deferred its final decision whether or not to nationalise "strategic assets" to a later conference.

The mining sector ${ }^{15}$ has slipped from being the largest sector and employer in the South African economy during the 1980 s at the height of the apartheid state as political and economic reforms, modernisation and new global markets opened to a democratic South Africa. The economy has transformed to being led by strong financial and telecommunications service sectors with little growth in new employment, over these three decades. Mere weeks after the fateful Marikana shootings State President Jacob Zuma called a meeting between government, big business and the trade unions where the Minister of Mining, Susan Shabangu, warned the ANC that if it wanted to save the economy it should not keep the question of nationalising the mines on its agenda (City Press, 13 Oct, 2012). Shabangu said it was going to be "very difficult" to restore investment confidence. Standard \& Poor (S\&P) had downgraded the country's risk assessment for investors. ${ }^{16} \mathrm{~A}$ month before, Moody's Analytics ${ }^{17}$ had cut the country's 
credit rating and downgraded the country's top five banks. Moody's had voiced its concern over the government's ability to solve economic problems suggesting it was moving closer to "non-investor" status. While not referring to nationalisation of mines, S\&P said the ANC's future policy frameworks were likely to be influenced by the mining strikes and more populist positions in the lead-up to the 2014 presidential elections.

Stephen Grootes writing for The Guardian (June 25, 2014) in a report titled "End of South Africa's platinum mine strike signals end of ANC domination,". called the strike

the most significant non -African National Congress action to help black people since the fall of apartheid. This is a very real demonstration of political power by an organisation that is black, and not a part of the ANC. (The Guardian, June 25, 2014.)

The political rhetoric arising from these threats to the economy are among the stark contrasts and increasing tensions within post apartheid South Africa. The ongoing strikes became the major challenge to the ANC in coping not only with the trade unions, but also the softening demand for commodities from the global economy.

While this political storm was brewing, it was amplified by the sacking of 12,000 workers on October 5, 2012, six weeks after the shootings at Lonmin, by the world's biggest platinum producer Anglo American Platinum, or Amplats, a subsidiary of London-listed Anglo-American (The Guardian, 5 Oct 2012). The Amplats sackings followed three weeks of strikes over pay and working conditions at Amplats and the bosses refused to offer a pay raise similar to Lonmin's, although the chief executive, Chris Griffith, did suggest that a salary review due in 2016 could start earlier. The sacking followed a day of violent clashes between South African police and workers that left one person dead. The strike was amongst the largest contributing factors that led to four of the firm's five mines being shut down in the Rustenburg area, 70 miles from Johannesburg, costing Amplats production of 39,000 ounces of platinum, worth $£ 51 \mathrm{~m}$ (US $\$ 86 \mathrm{~m} / \mathrm{R} 686.7 \mathrm{~m}$ ), according to the company. A leading financial analyst, lan Cruickshanks, said South Africa was no longer "the shining example of a well managed democracy on the continent" and warned that the South African currency, the rand, would weaken (City 
Press, 13 Oct 2012). Minister Shabangu warned that investor loss of confidence would result from the protracted strikes, which was spiralling through the whole industry from platinum to gold mining and then to coal. The rolling strikes continued over 20 months, and then on Wednesday June 25, 2014 as tens of thousands of platinum miners returned to work after the biggest strike in South African mining history -- five continuous months -- the companies released information of their combined losses. In platinum production the loss amounted to 40 percent of global production of the precious metal and had cost Lonmin, Anglo American Platinum and Impala Platinum a combined 24 billion rand ( $\$ 2.25$ billion) in lost revenue. (Reuters, 25 June 2014). These factors conspired against the mining industry that was trying to transform itself to a sector that would attract global investors. The mining industry was described by Andrew England writing for the Financial Times online (The Big Read of April 1, 2014) as being "stuck in the past" still benefitting from the exploitative migrant labour system of the old apartheid state.

\section{b) Migrant Labour}

The effects of the migrant labour system, which was the backbone of the apartheid economy, are still evident in the industrial and mining sectors. The crux of the challenge to this sector is to change the labour model, as the migrant labour system is so deeply entrenched and has been the main source of jobs for many poor communities, (Financial Times, April 2014). Yet changing the labour model is a slow process unless the government is prepared to work with the mining companies and the trade unions to put their resources together to overhaul the sector that is the most lucrative resource in the economy. Inequalities and continued lack of services are starkly evident in the urban-rural divide. One third are contract workers employed by labour brokers for the mines, with lower wages and no medical or pension benefits. Most of the migrants from the Eastern Cape, KwaZulu-Natal or Lesotho are from rural areas where populations are dependent on subsistence farming and women are left in charge of the crops as well as child rearing. The underground workers at Marikana were predominantly from the Eastern Cape, one of the poorest provinces in South Africa, with a history of migrant 
labour to the mines. Many hundreds of them were trade union members at the time of the Marikana strikes.

The lead researcher for the Bench Marks Foundation, David van Wyk, (2011, p.66) ${ }^{18}$.described how Lonmin experienced violent community protests at its Marikana operations in 2011as "an indication of communities frustrated and angry with the mining company". A Bench Marks report on corporate social responsibility in the platinum industry relating to ways of transforming the migrant labour system, was released in the same month as the Marikana shootings. It found that the high reliance on contract workers was a cause of the poor safety in mines:

... and is usually poorly paid, poorly trained and educated, and poorly accommodated.... Sub-contracted labour also lacks long term familiarity with the work environment and culture, being highly mobile between jobs. Therefore, sub-contracted workers compromise the health and safety of other workers. (Van Wyk, 2011, p.66)

Noting the high levels of unemployment in general and youth unemployment in particular, the Foundation recommended mining companies should give preference to the training and employment of people from local communities. Mining companies in the district could pool resources and establish a training centre or mining college. All companies should employ mine workers permanently and end their use of subcontractors and labour brokers. The Foundation supported COSATU's call to ban labour brokering and sub-contracting, and called on all companies to give serious attention to this issue. (p. 128) $)^{19}$

Another factor resulting in the strike at Lonmin was the significance of changes in labour recruitment and housing (Alexander, 2013). In 2010 only 18\% of Lonmin's workers were from local communities, while $82 \%$ were immigrants (both union members and contract workers), mostly from within South Africa.

Alexander says labour migrancy should not be confused with the migrant labour system. The latter was institutionalised in the late 19th century, in theory as a means of supplying 'cheap labour' as it was subsidised by rural production. "Today the reverse 
happens, as migrant workers' budgets must include support for impoverished rural families, and their pay though low by international standards, and in comparison to bosses, is higher than most other South African workers. (Alexander, 2013, p. 611.) The mining sector's dependence on migrant workers is a way of cutting costs and weakens trade union organisation since contract workers are paid on average $60 \%$ of the wages of permanent workers for the same work. They can be sacked more easily and are often expected to work in more dangerous locations than permanent workers. According to the Bench Marks Foundation, contract workers constitute $30 \%$ of the workforce. (Sapa, 2013 and Peter Alexander, 2013).

One of the most sensitive issues confronting employers in the mining sector after the transition from the apartheid state, concerns the housing of workers. Under apartheid all blacks in the city areas were regarded as "temporary sojourners" with no rights of permanency. The same attitude applied to migrant workers who would return to the socalled "homelands" or reserves after their periods of employment on the mines. Today, the consideration of providing proper family housing to migrants and a sense of permanence, has hardly been in open discussion in the mining sector.

\section{c) Peri-urban poverty and poor housing}

While some mining companies have programmes for hiring workers in local communities there is little or no open discussion on resettling migrant workers with their families on site or nearby the mines. Whatever plans Lonmin had, it failed to deliver the 5500 houses it was obliged to build to comply with its mining rights, and was found to have built just three show houses.

Housing is not a side issue in the events surrounding Marikana: the abject living conditions of the miners is at the root of discontent. (GroundUp 16, Aug, 2015.) -

After the first democratic elections in 1994, mining companies came under pressure to replace the hostel system for migrant labour. The inheritance from the old apartheid system was a lack of housing across the country as millions of people were forced into the so called "homelands", remote from the economic hubs in and around cities. 
Gentle (2014) describes how from 1994 workers throughout the country faced a housing crisis with millions of people living in shack developments or in the rented rooms in backyards, described as "informal settlements". Rural livelihoods had collapsed with small towns becoming ghettos of the unemployed, youth and women. In the absence of houses or services supplied by local authorities migrant workers set up informal settlements and lived in squalid camps around Rustenburg without running water, electricity or sewerage.

There was a seamless continuity, or rather a toxic cocktail of "workplace" and "community issues" that came together to fuel their militancy. (Gentle, 2014)

The development of a violent situation at Lonmin's Marikana mine was an example of exploitation by the mines, says the Bench Marks Foundation. ${ }^{20}$

Workers are not getting a fair share of the benefits of mining nor are the surrounding communities. Lack of employment opportunities for local youth, squalid living conditions, unemployment and growing inequalities contribute to this mess. (Sapa, 17 Aug, 2012) Michael Solomon, chairman of the Mineral Economics Division of the Southern African Institute of Mining and Metallurgy said the problems faced by the industry today "were precipitated by the system of migrant labour but ironically really came about by attempts to reverse the system." (England, 1 April, 2014). In the post apartheid era the mining houses, in response to demands from the NUM to deliver decent home ownership to mineworkers, sought to address the worst features of the apartheid-based migrancy legacy - the single-men's hostels - by introducing family accommodation for employees near the mines. This initiative took the form of a home ownership bond subsidy offered to employees to purchase a family unit. Then to ensure equity in the distribution of employee benefits amongst all strata of employees, the mining houses sought to address the needs of the migrants from afar (primarily those from Mozambique, Lesotho and the Eastern Cape) by offering an equivalent benefit in the form of a living-outallowance rather than live in the company hostels. Companies offered workers a "livingout allowance", currently about R1,830/US\$190 a month, to those who opted for noncompany accommodation. Migrants took this allowance, preferring the cash reward to 
supplement their pay packets, and headed for the shacklands to create their homes (GroundUp 16, Aug, 2015.). Many jumped at the opportunity. "The unintended consequences was that tens of thousands of miners moved into informal settlements sharing toilets and taps with dozens of others. Most miners visit their families only twice a year and many start second families around the mines, increasing the burden on their salaries. The result is high debts, vulnerability to loan sharks and rising frustrations.". (Alexander, 2013, p.611 and England, 2014). Regarding the living-out allowance for housing, in place of living in the mining hostels, Alexander says only $10 \%$ of the workforce continued to live in company accommodation. Several attempts at reform have faltered.

One of the big three producers, Impala Platinum, for five years recruited only locally in an effort to foster a more stable labour environment and to counter some of the social concerns. The problems were particularly acute in platinum mining. Impala's changes created their own unintended consequences. Jobseekers from rural districts simply moved to the platinum belt where they falsely acquired documentation from chiefs and officials to prove they were locals. Impala spokesman, Johan Theron, group executive for corporate relations, warned that the change meant the mines were not dismantling the migrant system, but reducing their own transaction costs, at the expense of the migrants, as the mines were bringing job seekers to Rustenburg (the platinum mining belt) as opposed to going and recruiting from where they reside.

The attempt to dismantle the migrant labour system risked "inflicting serious economic consequences on rural economies such as Lusikisiki in the Eastern Cape. (England, 2014).

Another key stakeholder was Teba, a recruiting agency for the mining industry. Teba's managing director, Graham Herbert, noted that the agency, which mainly recruited in rural areas, had 300,000 job seekers desperate for work who would walk up to $600 \mathrm{kms}$ to their offices in response to radio announcements. 
The government was accused of failing to deliver basic services such as sanitation and water to informal settlements where many miners lived "amid mounting anger with corruption, incompetence and cronyism" (England,1 April 2014.) A feature of employment in the past 25 years has been unemployment levels averaging 40 percent across the country and reaching levels of 60 and 80 percent in rural areas and in the poorer provinces. Families in the rural areas rely on welfare grants and remittances from workers in the cities already living in poverty themselves. (Gentle, 2014).

In 1994, faced with a backlog of 1.5 million houses, the ANC government abandoned the idea of a programme for public housing, but enabled people to buy their own Reconstruction and Development Programme (RDP) houses from developers and municipalities. The problem with this course of action was that miners on their meager salaries became totally entangled in debt. Lonmin's own corporate social responsibility (CSR) programme included relatively minor commitments rather than engaging in its intended house-building programme. Lonmin's programme included the repair of houses in the vicinity of the mine that had become damaged by their mining operations; a plan to fix the faulty sewage system at Marikana; and to clean up bilharzia infected water sources in the area. Evidence that the method of recruiting workers was going awry was reflected in Lonmin committed to ending the use of local chiefs and councillors in the recruiting process because of the way they exploited their role with the workers. It was issues such as this that intimated the need for good communication between the employer Lonmin and its workers.

Anglican Bishop Jo Seoka, chairman of The Bench Marks Foundation, that had conducted annual research at Marikana on the progress of Lonmin's corporate responsibility programme, said the shootings could have been avoided if Lonmin had listened to the workers' grievances. The narrative that reflects Lonmin's refusal to meet the striking workers unless they were represented by the NUM remains a key flaw in the company's labour behaviour. There appeared to be absolute intransigence on Lonmin's part in coping with the strike as the situation deteriorated. The final report of the commission found that Lonmin did not sufficiently try to engage with workers on ending 
the strike or to protect its employees. Further, it found that Lonmin should be investigated for knowing the risks but failing to protect employees regarding the killings of two security staff, two assaults, and the killing of a non-striking worker.

Tolsi, writing in the Mail \& Guardian, said the Farlam Commission report also recommended that an investigation be conducted into Lonmin for not fulfilling its social and labour plan obligations to build 5500 houses between 2005 and 2011. "These obligations are integral to Lonmin retaining their platinum group metal mining rights in South Africa." Lonmin in that time only managed to build three show houses for their employees. A 2010 Lonmin report found that $50 \%$ of its workers living mainly in the township of Nkaneng close to the mine, were housed in shacks and lacked access to basic services such as running water and electricity. This was considered "a motivating factor behind the strike." Lonmin maintained that it had failed to build the 5,500 units because of the 2008 platinum price drop.

Dick Forslund, a senior economist, acting for the Mail \& Guardian claimed in a question and answer session with Lonmin that the company had sent illicit flows of R1.2-billion to Bermuda in the period 2008 to 2012, that would have allowed the company to meet the $\mathrm{R} 12,500$ wage demand of the striking rock-drill operators. ${ }^{21}$

In 2013, the company announced that it had donated the land, about 50 hectares with some serviced stands, to the government. A year later, the North West government pledged to build 2000 houses over three years in the area. Set for handover in January 2016,22 this project will see 292 'Breaking New Ground houses', two-bedroom units with an open-plan lounge and kitchen and bathroom with shower and toilet, built at a cost of R23-million (US $\$ 2.5 \mathrm{~m}$ ). A further 126 apartment-style rental stock units are also being completed. But the development is causing anger and confusion in the community. This is rental stock for people earning between R800 (US\$87.5) and R3 500 (US\$383) a month. Miners, who have seen their salaries increase beyond this following the gains of the 2012 and 2014 strikes, do not qualify. 
Tolsi reported that the company had provided formal housing, including hostels, for less than $10 \%$ of its directly employed staff, which numbered about 24000 in 2012. "Lonmin also promised that a certain number of jobs would be filled by people from ward 32, but the councilor is selling the jobs to people from outside the community." Unemployment and access to housing coalesced in angry protests in late June 2015, when mainly young residents of ward 32, which includes Marikana Extension Two, marched through Marikana town and barricaded the streets with burning tyres, tree branches and rocks. Tolsi reported that the protests had stalled construction for about two weeks, raising the ire of construction workers who allegedly attacked a public gathering of community members on June 12, causing them to flee. A 28-year-old female protester, who declined to give her name, said: "There is confusion because people say it's houses for the community but Lonmin say it's workers' houses. There's confusion; no-one knows who the houses are for and we are all desperate."

Greg Nicholson writing for the Daily Maverick three years after the Marikana shootings, quotes a Lonmin executive saying:

We have made it our business to engage extensively with the Greater Lonmin Community (GLC) so that we identify their needs accurately and prioritise these through a collaborative process. (Nicholson, 2015).

Lonmin, which has come under heavy criticism since the Marikana massacre for the living conditions its workers and those in the area endure, recently released a document detailing the progress on its community development plans since September 2012.

Through its programmes, it says 75 home-based 'carers' and 24 peer educators cared for 1,790 patients and 1,174 orphans and a number of upgrades were undertaken at local clinics. On education, it says 1,261 students enrolled in its school support programmes, with 3,749 children in 49 early childhood development centres benefiting from its programmes. It says R7.2-million (US\$667,000) has been spent on improving access to water and R17-million (US\$1.6m) on tarring roads in Wonderkop. Another R2.5million (US\$232,000) has gone to improving access to the sewer network in 
Wonderkop and Nkaneng. Lonmin says its infill apartment project will see an additional 4,000 family units developed over the next five years at a cost of R500m (US\$46.3m). And it has contributed 50 hectares for the development of 2,658 housing units at a cost R387-million (US\$33.1m). It has also earmarked another 134 hectares for the development of rental units.(Nicholson, 18 Aug. 2015.)

Nicholson found earlier that the challenges for transforming living conditions by Lonmin were complex. There had been high levels of migration to the mines and a lack of investment in infrastructure such as water, electricity and schools. Many employees didn't want to own a home in the area as they have a home elsewhere and opted for a living-out allowance, which they could spend on other consumables or send home while renting a shack in Marikana. The responsibilities for improvements shared between the government and the mining houses were unclear and required close cooperation. And, as Lonmin pointed out, "progress in housing is dependent on the financial success of Lonmin, meaning that a weak platinum group metals market negatively impacts on Lonmin's ability to meet housing targets". Perhaps that means some of the company's plans might be difficult given the current climate in mining.

Work is being done to improve living conditions in Marikana but it remains far too limited. (Nicholson, 18 Aug. 2015.)

Two years before, at the Farlam Commission of Inquiry, former Lonmin chief operating officer Mohamed Seedat conceded under cross-examination that housing conditions at Marikana were "truly appalling". He also conceded that the Lonmin's board and executive had, post facto, recognised the link between the critical shortage of affordable housing and the 2012 strike. Seedat maintained, however, that Lonmin's social and labour plan (SLP) promises did not require the building of houses but were, rather, an obligation to broker an interaction between the company's workers and private financial institutions so that the former could access mortgage bonds. Lawyers acting for the families of dead strikers at the Farlam Commission, contradicted Lonmin's attempt to wash its hands of the legally-binding obligation to build 5,500 houses, arguing that this put the company's license to mine at Marikana in jeopardy. 
Despite Lonmin's pledge in 2006 to build more than 5,000 houses for its workers, only three new houses were built. Ironically this last line on poverty and inequality reflected how President Zuma first addressed the nation on radio and television on the shootings. Most of the workers lived in shacks which were in darkness since many of the homes in Marikana were not connected to the electrical grid, and those that were connected were hit by a power cut. (Shenker, The Guardian, 2014).

The poor living conditions of miners at Marikana became the focus of the trade unions and in turn the media coverage and cause of the strike action. What the media failed to explore or document was the mining sector's method of transforming rural agriculturalist recruits into mining workers, who work in hazardous conditions underground using modern machinery. Much of this documentation should have also been the task of trade unions.

\section{d) Loss of bargaining power}

The effect of the National Union of Mineworkers (NUM) and the labour federation Cosatu failing to take up the cause of the workers at Lonmin, suggests a collapse of the accepted method of industry negotiating with workers. This resulted in a wildcat strike that with the violence and the murder of two policemen and two Lonmin guards in the preceding week, was categorised as 'criminal' behavior. Lonmin then called in the police, who were given carte blanche to sort out the strikers. What became evident is that a new generation of workers emerged, seeking new freedoms for individuals rather than collective expression; that refused to be limited by the NUM trade union hierarchy or the rules governing wage negotiations with the union. They were enticed by the companies offering them "housing allowances" and the relative freedoms of living outside the mine hostels (economist Loane Sharp, 2014). The wage negotiations were held privately and their outcomes were complex. The media had difficulty reporting on the outcome as strikes continued for two years on a range of platinum mines. ${ }^{23}$ Firstly, the success of the strikers in being able to reach a deal with Lonmin after the shootings, displays how adamant they were to achieve their goal and at the same time how lacking they were in negotiation finesse. There were a number of stakeholders and leaders 
involved in the negotiations who were brought in to mediate an outcome. A deal was struck. However the striking workers and Lonmin have had to cope with the unintended outcomes of a rushed agreement. There were several media versions of the way the final salary offer was made signaling a level of confusion both on the side of Lonmin and the striker leadership. The following section will describe how events unfolded. The Government Commission for Conciliation, Mediation and Arbitration (CCMA) ${ }^{24}$ was tasked with hearing the workers' point of view.

On 18 August 2012, two days after the police shootings, the striking rock drillers at Lonmin demanded an increase from Rands 4,160 a month (US\$500) a month to $\mathrm{R} 12,500$ (US $\$ 1,500$ ) a month (or R160 /US $\$ 20$ a day in a 25-day working month to R500/US\$60 a day). The South African Press Association (Sapa, 20 Sept, 2012) reported on a conditional "deal" mooted by Lonmin, making it obligatory for the striking miners to return to work at $7 \mathrm{am}$ that day in return for pay rises of between $11 \%$ to $22 \%$, plus bonuses. Phillip de Wet (21 Sept 2012), reporting for Mail \& Guardian, describes how Lonmin's striking workers accepted a compromise pay deal based on fear of the mine's closure and of a threatening police presence. He said "Lonmin, at least at first, focused solely on restarting production and was unwilling to make concessions until that happened." He quotes Afzul Soobedaar, who acted as the Commission mediator for most of the negotiations: When I came down from the mountain [the hill at Marikana where striking workers routinely gathered], I realised that this was a not a labour dispute. It was manifesting as a labour dispute, but it was all about frustration with living conditions, inequality, poverty,' (Mail \& Guardian, 21 Sept, 2012).

Soobedaar said the experience of talking to the workers "shook him profoundly." Not only because of the accusations that he was a government stooge or the threats of violence, but his fears seemed justified when worker representatives finally agreed to lower their demand by 1 Rand (14 US cents) from R12,500 demand to R12,499.

That, they said, was as low as they would go, because anything else would be an insult to the spirits of those who had died, deadlocking the negotiations in irrationality. (Mail \& Guardian 21 Sept, 2012 
The blood spilt at Marikana demanded respect from the workers, Soobedaar urged the workers, adding that the blood was spilt in pursuit of South African democracy and that therefore a lawful process had to be followed.

Secondly, the South African Council of Churches (SACC) and Congress of Traditional Leaders (Contralesa) were also brought in to ease the communication between Lonmin and the striking workers. The SACC president, Bishop Joe Seoka, at various times a player and referee in the talks, took a slightly different approach to the CCMA:

We said to them they cannot hold on to the past, that those people were dead, but they had families and the living have families and must be mindful of their own needs. Those arguments seemed to fail, just as the arguments for disarming the striking group had failed. (Mail \& Guardian 21 Sept, 2012).

In contrast, Chief Phathekile Holomisa, the leader of the (Contralesa) that was also involved, explained by saying:

It is normal for a man in a village to carry a stick, because of dogs or whatever, but if you are not fighting anyone it is not necessary to carry a spear or a machete. Emotions were too high for them to understand that." (Mail \& Guardian, 21 Sept, 2012).

In his interpretation of the agreement the journalist De Wet said: "There was no agreement between the CCMA, the SACC and Contralesa on peace or process, or the need for achievable demands, or the real threat of Lonmin going under and all the workers losing their jobs, seemed to succeed. Some participants blamed the inexperience of those representing the workers, others believed they were simply afraid of being killed by those they represented if they were seen to have failed. Things looked grim."

Thirdly, the strikers, who refused to be represented by the unions, elected their own leaders. At a critical point in the negotiations they sought the help of the unions (not named) that agreed to be available on condition that the AMCU was excluded from the discussion. The Mail and Guardian reported that the unions involved were at pains to 
explain to the workers that they were vulnerable in their unprotected strike which could lead to their dismissal by Lonmin.

They told them how badly Lonmin was faring; how a higher settlement would mean job losses; and how salary structures worked. That, it seems, was the crucial breakthrough. (Mail \& Guardian, 21 Sept, 2012).

Achieving a settlement was critical, and this had to be achieved sooner rather than later. The agreement would cost the union dearly because it set a precedent that showed that wildcat strikes could be effective. Some workers told the Mail and Guardian that the breakthrough came thanks to an alliance between workers and the Council of Churches. Others said it was because Lonmin and its employees had found a common purpose in their joint-survival; while yet others were certain the fear of being fired finally trumped the fears of those waiting on the koppie. What they did agree on, however, was that impossible negotiations suddenly turned into simple wage talks and a resolution was easily found. After the settlement the striking workers felt no better off because they had been forced to accept the final offer. Heidi Swart, writing for the Mail and Guardian (21 Sept. 2012), reported some Marikana miners felt they were no better off than before the strike, after Lonmin offered the striking workers a $22 \%$ pay hike. Lonmin told her the offer was printed on a piece of paper, stamped in red in capital letters, 'UPDATED OFFER'. It listed current salaries and what the increases would be. It also said miners would receive "R1,500 once off (a grant termed "a bonus") if this offer is accepted and they returned to work on Wednesday 19 September 2012". This was eventually raised to R2,000. Sapa said the increases fell a little short of demands for a monthly salary of R12,500. And writing in August 2014 Gentle says a settlement was reached that ensured a $10-20 \%$ annual increase each year until the demand amount is reached.

Overall workers' wages and salaries as a percentage of national income have been dropping every year and were overtaken in 1999 by profits. (Gentle 2014)

The National Union of Mineworkers (NUM), the country's largest single trade union, which did not represent the strikers in reaching the deal, said the wildcat strike at Lonmin's could prompt other miners to act without going through union-approved 
channels. NUM general secretary Frans Baleni told the South African Press Association (20 Aug, 2012) that the outcome of this unprotected strike was in contradiction of the normal bargaining process.

Fourthly, the deal had a negative effect on Lonmin's reputation and the company began implementing its own set of changes. Sapa reported that Lonmin defended the deal because it had brought an end to the difficult labour dispute. A London-based analyst, Peter Attard Montalto, argued that the mine was "caving in" and risked creating "moral hazard and contagion" (Sapa, 20 Aug, 2012.) The platinum mining companies began slowly to address the living conditions of their workers and their own losses. Lonmin was hardest hit of South Africa's major platinum producers. An estimated $40 \%$ of the world's platinum production was shut down as a result.

The story line of Marikana unraveled over many months after the shootings, and in the build-up as well as during the 300 sittings of the Farlam Commission. In the 17 months after the police shooting of 112 workers of whom 34 died, the poor living conditions and pay levels of mining workers remain the dominant concerns. In the three years since the police shootings of workers in Marikana and a full year since the end of the strike, the media has kept up a formal set of reminders of what happened there, and periodic questioning of the mining companies on their programmes for change. Most of the coverage, however, has been unremarkable failing to hold the ANC and Cosatu to account.

\section{e) Slow transformation of the mining sector}

"Change is too slow". This is the main message coming from industry and media pundits as they comment on the mining industry 20 years after the ANC first took power. Change is needed in the labour model. Companies that were poised to implement new corporate social responsibility protocols for their workers are, given the continuing global recession in 2015, cutting jobs on a vast scale, generating a new crisis in the mining sector. Despite the urgency attached to ensure greater equity in the disparity between the production of wealth amongst the mining shareholders and directors, and 
the provision of safe, rewarding employment to labour, the actual outcome is more likely to increase the inequality gap. The economic indicators for South Africa were already seeing the impact of waning commodity markets in August 2015. The gross domestic product fell by $1.3 \%$ quarter-on-quarter, with mining contracting by $6.8 \%$, manufacturing taking a similar hit, and agriculture contracting by $17 \%$. With low commodity prices and rising costs, mining houses in July and August 2015 announced plans to shed thousands of jobs in gold, coal, iron ore and platinum, at companies including Anglo American, Glencore, Kumba Iron Ore, Sibanye Gold and Lonmin (Nicholson, 27 Aug. 2015, Daily Maverick). Economic Development Minister Ebrahim Patel has admitted the mining industry is in trouble. The Democratic Alliance's James Lorimer has said: "Make no mistake, it's carnage out there. There are jobs going left, right and centre and there are going to be a lot more [cuts]." (Daily Maverick, 2015).

In mid-August 2015, President Jacob Zuma related his plans to reignite growth and boost job creation through Operation Phakisa, a "Big Fast Results Methodology" that was used successfully to achieve rapid economic transformation in Malaysia. ${ }^{25}$ The mining sector remains a key strategic sector within the ANC's policy, and Zuma noted with concern that "an alarming number of companies were loss-making" - at August prices $40 \%$ of the country's platinum mining sector and $31 \%$ of the gold mining sector were loss-makers, and investment in exploration and extraction had dropped significantly. The ANC and its alliance partners have been critical of the mining companies retrenchments, claiming they were cutting jobs as a knee-jerk reaction to cyclical commodity prices. The idea of engaging the mining sector in talks with the state was the ANC's plan to keep looking to longer-term responses like launching a new state-owned mining company, promoting local development and ensuring companies comply with the Mining Charter. (Daily Maverick, 2015).

At this delicate economic juncture, the political pressures on the mining sector required that the media keep a sharp focus on labour, and the possibility of conflict and violence that could be ignited within the sector. The Mining Charter, launched in September 2010 , had as its main focus the need to facilitate the sustainable transformation and 
development of its mining industry, with emphasis on a target of $26 \%$ black ownership of the country's mining assets by 2014 .

Bua News, a news service operated by the Government Communication and Information System (GCIS), reported that the Mineral Resources Minister, Susan Shabangu, had warned that transformation within the sector has been "disappointingly slow." According to the assessment at that time, white men and women continued to dominate top management and technical positions in South Africa's mining industry, earning much more than their black counterparts, regardless of skill and experience. The racial ownership pattern of the country's mining assets has remained largely unchanged, with only $8.9 \%$ black ownership attained by 2009 against the target of $15 \%$. The reviewed Mining Charter sought to correct this, putting emphasis on $26 \%$ of SA's mining assets being Black Economic Empowerment (BEE) compliant by 2014. Clearly that target was not reached. The Charter makes provision for the complete elimination of hostels on South Africa's mines by 2014 , and introduced a sustainable element, "premised on the understanding that the social license to operate includes the environment, health and safety performance. Non-compliant companies could face penalties that would include revoking their mining licenses. (Bua News, 2010). In the post-apartheid period, the transformation of racial ratios in mine ownership, the radical change required in the labour model and the shrinking economy and possible lay-offs require a vigilant and informed media to unpack the complexities using both financial and labour journalists.

Marikana brought into sharp focus several issues that remained undercurrents in South Africa since the apartheid era and the mining sector itself. As the country's economy continues to shrink, mining stakeholders have come up with 10 initiatives to save jobs and ensure the industry remains viable. They report that the agreement could include some novel solutions such as pushing for BRICS nations (Brazil, Russia, India, China and South Africa) to invest in platinum as an asset reserve for their central banks. Reuters reports there was an agreement to streamline retrenchment processes, which was likely a compromise from unions and the state to avoid immediate job losses. 
The proposed 10 interventions are also said to include commitments to delay job cuts and to seal, rather than mothball, distressed mines. (Daily Maverick and Reuters report, 27 Aug. 2015). Anglo American CEO Mark Cutifani, whose company plans to cut half of its global workforce, recently called for reform of the labour system. "If we can work with labour and the government to negotiate, navigate and talk to a more flexible labour structure - I'm not asking people to work more hours - to address migrant labour in a more constructive way and to address the social issues and pressures we have, then we could operate our plants more hours, which provides more employment," said Cutifani. He suggested an increase in the hours of production could remedy the immediate focus of an industry threatening to cut thousands of jobs. (Daily Maverick, 27 Aug 2015). To take control of economic hard times the platinum industry executives and trade union leaders and government need to take account of their conflicting interests and different historical factors that contribute to these political and economic tensions. Importantly, the urgency of addressing migrant labour options and living conditions on or near the mines has become a new arena of political and economic discourse within the country, thanks to the investigation of mainly the foreign media where socially responsible investment is a priority.

\section{Conclusion}

The Marikana experience has demonstrated the injustice and dehumanising exploitation of workers in the platinum mining industry. The British company Lonmin became an extraordinary wealth generator and the company remains adept at working in high risk environments. However, the pattern of forming partnerships with political elites, while continuing to profit from cheap labour generated by rural people, contributed to inequalities that strain a new democracy like South Africa. The mining sector has yet to come to terms with its history of the migrant labour system. Modernising trends have halted the practice of recruiting workers en masse and housing them in dehumanizing single sex hostels. However, the new migratory labour practice that is evolving is more individualistic and includes contract workers. These new labour practices are resulting in loss of bargaining power and loss of job security amongst the poorest paid workforce 
in the global mining industries. The need to build proper family housing remains a key agenda item for the unions. Improving living conditions around the mines for workers places a concomitant priority on government to develop new towns around the mines, provide housing, social infrastructure for health, education and infrastructure and for business development.

Marikana demonstrated the unyielding passion of exploited workers fighting for their rights to extend to all aspects of their lives: safety on the job; reasonable levels of pay given the inherent value in the commodity they are mining; proper housing and facilities, and job security. Social and economic development in South Africa continues to evolve and the media have an important role to play, in keeping informed communities engaged in societal goals. The media have reflected that pay levels in the South African mining sector are among the lowest in the world. Though patchy in their ability to capture the Marikana dynamics, the economic narrative that the media have projected since the shootings has brought to light how cost-cutting methods of employment using contractors and the shelling out of cash grants to avoid housing workers properly. Both are examples of poor practices that provide little security in what should be a prestigious industry. 


\section{CHAPTER 3 : THE STRIKERS, AND THEIR WEAPONS AND 'MUTI' CULTURE}

In evaluating the media narratives of the striking mine workers much of the information is reconstructed by journalists and academic researchers in the days, months and three years following the strike and police action in August 2012. It often took months before good eyewitness accounts reflected the events in a coherent way. Also as a result of this, the real life perceptions of workers were missing at the start.

This chapter will reflect on the life of the migrant worker Mambush, the leader of the striking rock drillers, and how human interest emerges in the media narratives of the workers, most coming mainly from rural areas to the mines in search of jobs. It reflects the mass of workers finding themselves living in a new community, close to a mine in peri-urban slum shack settlements. What becomes evident is the ongoing failure of Lonmin or the state, to provide adequate housing and services in the Marikana case. Secondly, by unpacking the narrative of the culture of carrying tribal weapons, this chapter will investigate the communities from which they come, their tribal culture and the traditional carrying of tribal weapons by the men. Thirdly, it will reflect on the use of tribal 'muti', tribal medicine, and the description of strikers queuing up for a herbalist ('inyanga' in Zulu or 'ixwele' in Xhosa) who treats them with herbs they believe will protect them in battle against their enemies; and finally the mass "cleansing ceremony" for the families of those killed, to try to put their tragic deaths to rest.

This intensely human and cultural side of the striking workers at Marikana was captured by reporters and photographers. Controversy persists over trade union workers carrying weapons at strikes. In the analysis of why workers from tribal cultures bear arms, I will compare how the police behaved in the apartheid era when they allowed the carrying of weapons during the 1980's in the war in KwaZulu-Natal between the Zulu tribal group Inkatha and the Mass Democratic Movement, at that time, the underground African National Congress (ANC), the trade union federation, the Congress of South African Trade Unions (Cosatu) and United Democratic Front (UDF). ${ }^{26}$ While in Marikana, the 
police took the decision not to allow them to carry arms, and tried to disarm them. This demand by the police is badly handled according to reporters and the Farlam Commission.

Photo-journalism contributes strongly to this human interest narrative that will be managed in a separate chapter. A valuable part of the reporting of Marikana has been the visuals -- the photographs of the estimated 3, 000 striking rock drillers covering the main hills. There are at least four examples of live footage by the media of the shootings on August $16,{ }^{27}$ and hundreds of photographs of the police activities on that day. Besides these, there are remarkable close-ups of individuals or groups and large crowds of strikers often bearing weapons, highly organised and seemingly strident.

In contrast, there is the evident poverty and despair in the shack settlements, a social milieu where local miners live with their families. The key drivers in the nature of migratory labour are poverty and the need to earn a living. In the South African case, the poverty of rural areas, that 20 years ago under apartheid were termed 'homelands', were overcrowded and overworked agriculturally. The only obvious way of supplementing subsistence farming historically was through gold or coal mining as part of the migrant labour system. Workers were recruited in rural areas and brought to the mine hostels for temporary work. I will investigate these dynamics in what follows.

\section{a) The transformation of the rural man to an urban mine worker: the narrative of Mambush.}

Few if any of the media reports reflected the dramatic transition that mining workers have to make from rural to mine contexts. They fail to examine the process of employment of labour in the mining sector, and how workers are initiated into a new way of life. The migrant labour system was a hundred years in the making yet continues to exploit workers. For the media, careful consideration of their families, their housing and transport needs as well as their training, conditions of work and levels of payment and benefits, are all vital elements in reflecting how a workforce is treated, and whether it gets its fair share of the wealth generated by the lucrative platinum mining sector. As 
important, is to reflect some of the difficulties workers have in adjusting to the new way of life.

Academic researcher, Dunbar Moodie (1994) describes how South African mining experience historically differs from the Western norm in that the workers are located within a wider system of migrant labour that necessitates long-term separation from home and family "in an alien living environment."

Work conflicts and solidarities are not dissipated by the end of the day by miners' return from work to private company owned homes but are intensified by their crowding into male-only compounds subject to tight management control. (Moodie, 1994, 21.)

He argues that the formal organization of the mine compound as a social institution was appropriated by migrant cultures for their own ends in a whole collections of social practices and networks by those miners able to retain a social and economic subsistence base in the countryside (Meyer 1980:58-59; Sitas 1985 as cited by Moodie). Many scholars have considered migrant workers "men of two worlds," (Moodie, 1994.)

Mambush, the rock drill operator from Thwalikhulu in the Pondoland district in the Eastern Cape is described by Ledwaba (16 Aug 2013) as:

A muscular, dark man of medium height with a thin mat of closely cropped hair. $\mathrm{He}$ takes the lead. He is holding a spear and 'incula' (sharpened steel rod) in one hand. A green shawl (referred to by others as a green blanket) is tied around his neck, and hangs down to his waist. (City Press, 2013)

He featured prominently in the events of the next three days. When Noki spoke to General Mpembe in Fanagalo, ${ }^{28}$ (the eclectic widely spoken mine language using Zulu, Xhosa, English and Afrikaans words). Ledwaba captured Noki standing on the fender of the police vehicle where he tells the police general in the armoured vehicle that the group of strikers had been at shaft K-3 waiting to speak to the employer, but that the 
employer would not meet with them and the workers were heading to the koppie where they were meeting to get feedback.

(Earlier) The Deputy Police Commissioner Mpembe told the men that they constitute an illegal gathering and are carrying dangerous weapons, which is also illegal. He asks them to lay down their weapons, upon which they will be allowed to proceed. (City Press, 2013). Now Noki replied saying: (The strikers) are only carrying the weapons to protect themselves against attacks by NUM members. Their fight, he says, is not against the police. All they want is to meet with their employer. If the police don't mind, they can accompany the group to the koppie to show they are not fighting them. (City Press, 2013). This exchange between Mambush and the general takes place with difficulty, as the general refuses to get out of his police vehicle, and Mambush has to address him by shouting, with his face right up against the closed windscreen.

vii) Photograph 7: Lucas Ledwaba, (City Press)

Lucas Ledwaba author of the first chapter "Guns and Spears" in the book titled We are Going to Kill Each Other Today written by six City Press journalists, set the scene on the eve of the police shootings on August 16, 2012:

The rhythmic clash of steel against steel and wood against steel adds menace to their singing. It is early spring. The air is still dusty after the dry winter months, and the sun is a huge orange ball hanging low in the sky. Unbeknown to the men and everyone else present, some of them will see the sun set for the very last time. By late afternoon the next day, men will lie in the dust and among the rocks, and soon 34 lives will have been snuffed out by bullets from police assault rifles and handguns. Another 71 will lie wounded, groaning in pain. (Ledwaba, 2015)

The emotional build-up of the striking rock-drill operators suggests a physical confrontation has become inevitable. We then follow the events with Mambush.

Nick Davies described Mambush as:

A rock-drill operator with no official rank - he emerged from the mass of black workers as a rebel leader demanding justice, while some of those who were once the spearhead 
of the fight against repression acted as a shield protecting privilege, exploitation and extreme violence. (The Guardian, 19 May, 2015)

Davies described how the miners live in the shadow of the Lonmin smelter, which "stands like a cathedral of commerce over a bleak landscape, its chimney reaching for heaven, its conveyor belt shuffling a fortune in unrefined platinum."

Their homes are one-room shacks. Some of them are built of breeze blocks; most are patchworks of rusting corrugated iron tacked onto frames of timber torn from local trees. There are no roads, only dirt tracks. As far as the eye can see, pylons march across the landscape like robot soldiers, bringing electricity to the mines, but most of the shacks have no power, though some steal it on cables that sag among the washing lines. (The Guardian, 2015)

Davies reported how "the mines have water to wash the ore, but not at their shacks. Some of the men share a communal tap, though many of them have been broken for months. Some drink from milky streams that run nearby." (The Guardian, 2015). It is essential to the narrative that Mambush as participant is recorded.

At the 3rd commemoration of the shootings, Davies (2015) interviewed Mbulelo Noki, Mambush's cousin. He reported that they grew up together in Thwalikhulu. The two boys were close. Mambush's father died before he was born, and so Mbulelo's father helped support the bereaved family. "As they reached adolescence, the cousins went together into the hills to build a hut and to go through the rituals and circumcision that marked their graduation to manhood. Later they worked together as rock-drill operators." (19 May 2015, The Guardian). Five days before the police shootings on Aug 16 , the two cousins received a message that their uncle - the younger brother to their fathers - had died of tuberculosis at the Impala mine. They set off to retrieve his body, so they missed the first sign of violence. Mbulelo wanted to leave to arrange their uncle's funeral, while Mambush was determined to join the strike. Davies related how that night, Mambush called his wife, Veronica, who was living with their two-year-old daughter, Asive, in Carletonville, a gold-mining town 90 miles to the west. This was the 
town where he had first worked as a miner, in 2004. In 2008, he had injured his shoulder in a rock fall and had gone to the medical station where Veronica was an administrative assistant. They had started a relationship that continued even though Mambush soon moved to Marikana, where the pay was better and the rock was harder and safer to mine than in Carletonville. (The Guardian, 2015.)

Davies reflected on Veronica's understanding of Mambush's labour concerns. These include his anger with the National Union of Mineworkers' (NUM) shop stewards for being taken out of the mine and being given pay rises, cars and mobile phones by Lonmin. She remembered how the union officials had stopped speaking for the people who elected them, and how Mambush had said "NUM is a sell-out." He had also spent time registering the Association of Mineworkers and Construction Union (Amcu). He had often talked of his difficulty of getting R5000 (US\$376) a month, so he could send most of it to his first family in the Eastern Cape, and pay for his own shack and food. Veronica had a college education and lived in a brick house. She told him that she and her baby could get by on her earnings each month. He found he had to borrow money at interest rates as high as $50 \%$. (Mambush's role in the events leading up to the shootings are reflected the next chapter.)

Lolah Nkosi, in "Social Impact of Mining," University of Johannesburg, 2014 described communal problems that need to be addressed. These included the threats to the agricultural lifestyle; disruption of traditional family life. ${ }^{29}$

The media narratives describe how the rock drillers on strike carried the main body of mineworkers with them into a general strike. They are regarded as the leadership core of the competing unions and literally "the men at the rock face." However, it remains clear that many are at odds with the NUM and, as a result, susceptible to persuasion by the emerging AMCU. This chapter goes on to explore how and why the workers carry elements of their tribal culture with them to the mines. 


\section{b) The culture of carrying tribal weapons.}

At Marikana the striking workers carried arms and their refusal to give them up to the police became the real reason for the shootings, rather than the claim that the police were being attacked as eye-witnesses to the Farlam Commission and the film Miners Shot Down proved.

The police at the Farlam Commission hearings over the past two years, were at pains to make known their series of very public yet unsuccessful attempts to get the strikers to disarm. Lucas Ledweba (City Press 18, Aug 2012) reporting at Marikana, described what he interpreted as a hierarchy among the strikers, the more militant numbering a few hundred, sat at the bottom of the hill, flanked by thousands. He referred to the militant group as resembling disciplined warriors. They are led by a tall dark man "draped in a green cape". Later described by others as "the man in the green blanket," and identified as Mgcineni Noki elected as one of the strike leaders. This was Mambush, who later died in the first shootings on August 16. The militants were armed with pangas, spears, clubs and sharpened steel rods. The strikers had fashioned strict rules governing the gathering:

No hats, no jewellery, no mobile phones, no cameras, and above all, strictly no women. And the workers were warned not to be seen speaking to strangers (meaning the media), which explained the stoic silence and nasty looks from some of the men walking to the hill when approached for interviews. (Ledwaba, City Press, 18 Aug. 2012.)

The police had warned journalists that the strikers were hostile, armed and dangerous. Ledwaba then described a verbal exchange and deal made with the man in the green cape, who helped to make three volunteers available for interviews. These were carried out in front of the seated thousands with the strikers speaking through a loudspeaker. In the interviews, the strikers (all from the Eastern Cape) said their demand of R12,500 a month (US\$1,500), "was an all or nothing" issue for them. By midday on the day of the shootings it had become clear that the strikers were not going to leave the hill despite numerous attempts by the police and officials of the two unions, NUM and AMCU, "to negotiate a truce". Ledwaba adds that the AMCU speakers were at least "given an ear 
by the strikers", while the NUM speakers were heckled and forced to retreat. He said it was becoming clear that the gathering was not going to end peacefully.

If they want to kill us they may as well do so" said a man addressing the strikers as more police reinforcements arrived on the scene. (City Press, 18 Aug. 2012.)

The position taken by the police was diametrically opposite to that taken by the police in the mid-1980s of the apartheid era. At that time when Inkatha's Zulu men carried weapons, the police did not disarm them. Community violence involving Inkatha in Natal Province in the 1980s was against the then underground ANC, the trade union federation Cosatu, and the United Democratic Front, a civic movement. In this ongoing war the police allowed the carrying of tribal weapons as it suited them, as they too were at war with the ANC.

However today, the police force works for the ANC, and in this case also for big business. At Marikana they found themselves up against striking workers whose members were carrying tribal weapons. There were two main reasons for disarming them: first the ANC has tried to eradicate tribalism as an outmoded form of behaviour of the past, as was their continuing to carry tribal weapons; and secondly the police had been informed by none other than the deputy president of the ANC, that the striking workers were behaving in a criminal manner, and not as bona fide trade unionists.

These reasons add to police motivation to sort out the union once and for all by shooting the strikers. I submit that disarming the workers was the 'pretence', the ruse. Events that well may have cropped up, such as the claim of evidence that a striker fired a gun at the police in provocation before the shootings, could have been a further, and more urgent rationale to open fire.

Academic lecturer, Nomalanga Mkhize (2014) in an opinion piece in the Mail \& Guardian, said the ANC (and by implication, the police as well) had been tone deaf to the cultural symbolism of violence employed by the Marikana workers. She says: 
The carrying of weapons by Zulu workers is steeped in masculine codes and warrior identity. Once men mobilise in this form, they begin to see themselves as fighting to the death, with honour and principle at stake. (Mkhize, 2014, Mail \& Guardian)

She referred to the "dozens of bullet-riddled bodies being returned to KwaZulu-Natal villages for burial", saying there should have been extra caution in dealing with KwaZulu-Natal migrants, given their historical association with Inkatha politics, "which drew whole villages and townships into hellish violence in the late 1980s and 1990s." The ANC had showed particular "political bravery and creativity" to quell this violence at the time. It was sensitive to the cultural codes of "recalcitrant warlords and traditional leaders and their factions, to get them to buy into the new South Africa." She could not understand why the ANC overlooked these workers' cultural codes at Marikana and not acknowledge them in an effort to contain the situation. Mkhize described this culture as "steeped in masculine codes and warrior identity. Once men mobilise in this form, they begin to see themselves as fighting to the death, with honour and principle at stake." The protocols of cooling tempers occur when the men demonstrate their mutual respect by squatting in front of one another. "You can see an example in Rehad Desai's documentary Miners Shot Down, in an exchange between striking mine workers and a police general, who said all he wanted from them was their weapons."

What I saw in that scene was an all-too-familiar die-hard, no-surrender attitude I know from my uncles and brothers in rural KwaZulu-Natal. (Mail and Guardian, 2014).

She described how faction fighting has its roots in precolonial peer-to-peer combat and military training. With the advent of colonisation and the destruction of the old rural order due to land loss and the imposition of taxes in the "native reserves", faction fighting "morphed into vicious intergenerational feuds between men from rival clans and villages." She said the migration of young men to the mines and the penetration of the cash economy "disrupted male hierarchies in rural areas, creating a social context in which even petty disagreements could engulf whole villages." "This was also transplanted to the mines of the Witwatersrand. Because of the specific politics of KwaZulu-Natal, the violence of its migrants was also enmeshed with the political 
violence back home." She said anyone coming from KwaZulu-Natal would know that migrants from there would have another way to leverage their demands - "the threat of drawing in traditional leaders who do not support the ANC. In my mind's eye, I saw very clearly how it would have played out: the mine workers would have demanded that they be heard, otherwise back home in villages such as Nkandla there might be a fierce reckoning." She is writing from a personally well-informed position as a Zulu woman who understands the culture and behaviour of her brothers. We now look at how the politics of the apartheid government viewed the carrying of traditional weapons 25 years ago.

Rick Lyman (1991) of the Philadelphia Inquire ${ }^{30}$, wrote that as the violence escalated in Natal, President F.W. de Klerk's government banned the wielding of most weapons in public - but allowed the Zulus to continue carrying their "traditional" spears and clubs. However, the ANC insisted that de Klerk ban the carrying of all weapons, charging that the appearance of "traditional weapons" at mass events had often led to fresh bloodshed. At best, they said, the weapons were a needless provocation in already tense townships. Lyman said "Inkatha insists, just as strongly", that its members be allowed to continue carrying their weapons, particularly to mass tribal events.

They are a jealously guarded symbol of Zulu heritage, Inkatha says, and are needed to ensure the safety of those attending Zulu events from attack by pro-ANC opponents. (Lyman 1991, Philadelphia Inquirer.)

De Klerk then attempted to walk a middle line. After a day of private talks with Inkatha leader Mangosuthu Gatsha Buthelezi, de Klerk announced a partial ban on carrying traditional weapons at political events in officially designated "unrest areas." But the ANC remained dissatisfied.

All weapons must be banned, and not merely in certain areas or at certain events. (Lyman 1991, quoting Nelson Mandela, then Deputy President). 
Barry Marshall, curator of the KwaZulu Cultural Museum in the Zulu capital of Ulundi in northern Natal province, believes that non-Zulus miss the point about these weapons. Chief among these weapons, Marshall said, is the knobkerrie, a cane-like shaft of wood with a thick ball carved into one end. In battle, it could be used to bash skulls, but in everyday life it could be carried as a warning to others that its bearer was not to be trifled with. He added the assegai - a spear with a long tapering point that comes in two styles: long, for throwing, and short, for close-combat stabbing; and battle axes, ornately carved and wrapped in animal skins, that are normally carried only by high-ranking Zulus. Other primitive weaponry - such as machete-like pangas, originally used on South Africa's sugar-cane plantations, and knives or short-tipped spears - were not used by the great Zulu military leader Shaka's legions (1820s) and are therefore not considered true "traditional weapons," Marshall said. "Traditional weapons are the weapons that were carried into those battles and which Zulu men have carried for generations," Marshall said. "It's a symbol. They don't carry them to be aggressive."

We do not call these traditional weapons only as a trick to allow us to bring them to rallies. They are our heritage, and we cannot be without them. (Frank Mdlalose, Inkatha chairman to Lyman 1991).

While other tribes have slowly abandoned many of the traditional ways, the Zulus have steadfastly clung to theirs. The old ways are the glue that holds them together, keeping the traditional tribal power structure in place.

I say to the ANC, let this talk of Zulu cultural weapons being the instruments of death now cease" the king said. It is untrue. The call to ban the bearing of cultural weapons by Zulus is an insult to my manhood. It is an insult to the manhood of every Zulu man. (Zulu King Goodwill Zwelithini, in Lyman 1991).

The carrying of weapons by groups of workers whether unionised or not, remains controversial especially in a post-apartheid society where racism and violence was so prevalent. While having one of the most advanced democratic constitutions both South Africa (and the United States have a mix of cultures about what is appropriate in the 
ownership and the carrying and use of weapons. All societies have cultural histories that reflect physical and emotional traditions and practices, as well as the rites of passage of different age groups. The way people fight and the weapons they choose generally have traditions as do the ways they protect themselves in war and how they contend with death and dying.

Testifying at a session the Farlam Commission of Inquiry, Provincial deputy police commissioner William Mpembe said he pleaded with protesters to lay down their weapons in Marikana "I testified that as the overall commander, I took it upon myself to intervene on August 13" Two police officers were killed that day. (SAPA ${ }^{31} 18$, June, 2013). Commission chairperson retired judge lan Farlam asked Mpembe: "If you did that, persuading them to do as you say, we would not be here?" Mpembe said he believed the protesters would heed his call when he spoke to them directly. Vuyani Ngalwana, for the police, asked Mpembe whether he considered using lethal force on the protesters on August 13 to disperse them. "No, I did not consider that because crowd control does not allow the use of lethal force," Mpembe replied. He said he held an impromptu meeting with his commanders on the day to see how police could resolve the situation. A psychological debriefing on the state of the police officers' mental fitness to continue working at Marikana was also done then, said Mpembe.

\section{c) Secret rituals of the medicine man.}

Current Deputy Presidents, Cyril Ramaphosa and Kgalema Motlanthe, who was also President briefly, are both former secretary general's of the National Union of Mineworkers (NUM), and have had extensive experience of the transition that men make from a tribal culture to a working class culture that is mine- or city-based. For trade unionists to be carrying tribal weapons was, and is among the more controversial aspects of tribal behaviours but so are the rituals attendant to folklore and rites of passage.

The healers in traditional African medicine are the diviner (sangoma), and the herbalist (inyanga) are highly revered and respected in a society where illness is thought to be 
caused by witchcraft, pollution (contact with impure objects or occurrences) or through neglect of the ancestors. The pejorative term 'witchdoctor' is still in use in opposition to the transition to modern medicine.

Lieutenant-General Elias Mawela at a media briefing on Friday (Aug. 17, 2012) said:

"We were dealing with people who looked possessed, or believed the bullets would not work on them." (City Press, 18 Aug 2012.)

Motlanthe, said he believed that the mineworkers at Marikana before the shootings were in a muti-induced trance in which they would either kill or be killed. (Carol Paton, Business Day, 31 Aug. 2012). While giving a detailed explanation at a special press briefing, of how and why illegal and violent industrial action tended to occur in mining workplaces, Paton quotes Motlanthe:

The muti provided by a 'witchdoctor' played a central role. Many believed themselves invincible after being sprinkled with potions. (Paton in Business Day 31 Aug. 2012)

The combination of General Mawela's statement and that of Deputy President Motlanthe, appear to set up repeated references by the media apportioning responsibility for the shootings to the striking workers for being drug induced. The question remains as to whether many commentaries by the police, politicians or media on the use of drugs in ritual cleansing at Marikana, was based on hearsay, or not. Ledwaba described the night of 11 August 2012 when striking men gathered on the banks of a stream near the koppie. ${ }^{32}$

Under cover of darkness, they strip naked and undergo a ritual reminiscent of those undertaken by warriors over centuries. Supervised by a medicine man, they roast two live sheep, one black, another white, over a fire. Incisions are made on their ears, cheeks, backs, thighs and feet with a razor blade, and ashes from the fire, mixed with herbs, are rubbed into the wounds. This, they are told, will make them invincible. A firearm is produced and shots are fired at a box smeared with the concoction. Miraculously, the bullets do not penetrate the box ${ }^{33}$. (Ledwaba, Aug. 2013.) 
The men were now ready for war. The strikers regarded the work of the medicine man was to prepare them for battle with their enemies.

\section{d) The cleansing ceremony}

Each of the miners had a name, a family and a story to tell, a past and a future. Their relatives have waited more than 1,000 days to find out who was responsible for cutting those stories short and why. (The Guardian, 3 July, 2015.)

Ten months after the shootings tragedy occurred at Marikana, the Bojanala Platinum District Municipality organised "an open demonstration of concern and human care for the families of the victims of the shootings in a 'cleansing ceremony'. It was described by the media as an outpouring of grief and the possibility of coming to terms with the events of Marikana.

City Press, reporting on 17 June 2013, described the 'cleansing ceremony' as "successful and emotional". The Bojanala Platinum District Municipality has said."The ceremony was extremely emotional and the families broke down terribly for about an hour," spokesperson Archie Babeile said. "They were coming here for the first time since the massacre in August and it was quite difficult for them to come back to the area where they lost their family members." The families were booked into a hotel in Pretoria where they were attending the Marikana Commission of Inquiry into the deaths of 44 people, he said. Forty of the 44 families attended the cleansing ceremony. "The ritual went successfully well ... The families went out to the field where the tragedy occurred and slaughtered the sheep there. (17 June, 2013, City Press.)

"The cleansing ceremony was not only for the miners, but for all those who died in Marikana in August. The families said they were not hurt because their family members died, but how they died." The slaughtering of sheep and various rituals performed by each family in terms with their different cultures lasted about four hours, he said. Babeile said there were families who requested to perform the rituals at the exact place where their family members had died and not on the koppie. The municipality arranged for the ceremony to take place on the koppie and told the families that if they wanted to 
come back at a later stage, they could, he said. "They raised the concern late and there were no plans to go to those areas, but instead the municipality made a commitment that should they wish to perform rituals later, they should let us know and we will assist." To ensure that the ceremony did not turn into a political platform, no union T-shirts were allowed and white T-shirts were given to the families. White doves were released by the families as a sign of peace and reconciliation, he said. "The families regarded this as a means of closure," said Babeile. "The families indicated that they are happy that something was being done to heal the scars that are hugely visible within their hearts."

\section{Conclusion}

I submit that the social and psychological impact on the lives of rural people suddenly shunted into urban environments and then into factory environments or underground in the mines, requires research into every area of such transformation by the media. Little of the social and psychological impact of this has been taken note of by government or the sectors that utilize migratory labour during this social upheaval. Folklore and tradition are slowly giving way to psychology and modern religious expression. One of the problems experienced with tribal workers is that theirs is an oral culture and historically they have a lack of basic education and literacy. The huge emphasis on the social sciences in education has made few inroads in the mining sector; neither have modern systems of language instruction. This suggests the need to modernise the experience of the transformation from tribal agriculture to deep level mining with education and training for the attendant skills, while displaying care, compassion and humanity in focusing on the issues of family, housing and proper work conditions. The media has a key role to play in this process. Also evident was shallowness of the initial day to day reporting of the strike and the buildup to the police shootings of workers. There are only two in-depth reflections on the issue of workers carrying traditional arms; and there is little in-depth or investigative reporting on the use of drugs from herbalists or on the "cleansing ceremony" with most media relying on hearsay or using sources reflected by other media. 


\title{
CHAPTER 4: THE VIOLENT BUILD-UP TO "D-DAY"
}

\author{
'Mambush' was killed at Scene 1 after being shot 14 times by the police, including in his \\ head, neck, legs, buttock, elbow, calf and thighs. (Commentator and activist, Mark \\ Weinberg, personal Facebook post to commemorate the third anniversary of the \\ shootings, 15 August 2015.)
}

Brutal violence marred the first days of the strike and contributed to the police shootings of 112 workers, of whom 34 died at the scene. It has taken more than three years to unravel the contributing factors to what several writers describe as a "premeditated massacre". In this chapter I will investigate the narratives that contribute to the deepening understanding of the factors that caused the shootings. I will investigate four main themes that I have constructed from the reportage that spans three years of investigation by journalists and academics, as well as the Farlam Commission of Inquiry into the police shootings. These are:

a) The brutal hacking to death of 10 people by striking mine workers, including two policemen, and two Lonmin security staff, a NUM official and workers refusing to strike. This violence resulted in anger and fear on the part of the police bent on revenge.

b) NUM and Lonmin and the African National Congress (ANC) branded the wildcat strike illegal, and the strikers criminals, out of fear of escalating brutality from the strikers. This justified the call on the police to take action and becomes the rationale for Lonmin's failure to meet the strikers.

c) An internecine battle emerged between NUM and the aspirant new union AMCU. State intervention was sought to contain the strikes and violence that threatened to spread to other mines across the country. Because the fate of NUM and its ties to Cosatu, that is part of the ANC Government Alliance, the whole future of labour relations was put in abeyance.

d) The conflation of roles between the state, Lonmin and the police resulted in extreme use of force and power in a situation that might have been resolved as a labour dispute without violence. 
In this chapter I develop the narratives of successive incidents of violence that occurred in the week before the police shootings of striking workers on Aug. 16, referred to by the police as 'D-Day'. Sunday Aug 13 erupted in a spate of violent brutal deaths that included two policemen, two Lonmin security guards and four workers who refused to join the strike. Marinovich (8 Sept. 2012) recounted how the police attempted to disarm a group of 30 Marikana strikers trying to cross a field to the Karee mine where other miners had led a wildcat strike for better wages. When a police contingent tried to disarm them of their traditional weapons and they refused, the police opened fire on the strikers who retaliated by killing two policemen with pangas and injuring a third. In the final phase of build-up on the 16th to the police shootings, after successive attempts by the police to disarm the striking workers, the photo-journalist Marinovich, described how the police laid razor wire to trap the striking workers and in the process opened fire on 112 strikers, killing 34 or them.

An original member of the "Bang-bang Club"34 Marinovich wrote on Marikana for Daily Maverick, an independent online news and opinion producer. This chapter recounts the police case justifying their shootings as prepared for the Farlam Commission and also Greg Marinovich's two week appraisal of the police shootings at what is termed 'Scene 2 ' out of range to photographers, where workers were shot and killed but not recorded by the media. Marinovich evaluated the first media reports of the shootings and asserted that photography tells the story more accurately than writers do. This chapter relates the Farlam Commission's findings on the police shootings and concluding remarks that focus on Lonmin's failure to listen to worker grievances. Making sense of the many reports, and ever-deepening investigations as follow-up to these strikes, I have chosen these four aspects as keys to the complex and dynamic relationships between the main players. Also included here are the arrests after the police shootings, of 270 strikers who were charged with the murder of their 34 dead colleagues, a supreme irony given the history of "common purpose" clause used in the legal justification for the arrests and the police attempt to deflect responsibility for the shootings. 


\section{a) Brutality, fear and revenge}

I argue that the police failure to disarm the striking workers once they were called in by Lonmin to act against the strikers, led to a week of violent incidents that resulted in the strikers hacking two policemen to death. This heightened the police tensions, who then acted out of fear and revenge. It is suggested by leading academics and journalists who investigated the shootings using eyewitness accounts, that the mining company Lonmin acted in concert with the police who then went on to plan the use of a 'tactical response' that resulted in the shootings.

Poloko Tau, (13 Aug 2015, City Press) reported his experience three years before, to the day, that while sitting in a boardroom at Lonmin offices, with two City Press colleagues, they were warned of a "very dangerous group of heavily armed men" who were gathering on a hill next to Nkaneng settlement. They were told that the men on the hill were "faceless" and definitely not their workers. Tau said Lonmin was not prepared to engage the miners who were demanding that their salaries be raised to R12 500 a month (US\$1,533). While sitting there, mine officials told stories of how these "dangerous men" had hacked and stabbed some people. A call came in reporting to officials that a fourth body had been discovered next to the rail tracks in the area.

Then Tau described how with a group of journalists, on their way to the hill where the miners had gathered, they received a call saying that there was a confrontation between a group of striking miners and the police close to the K3 Shaft of the Karee platinum mine at Marikana. They could see a police helicopter overhead and heard "what sounded like gunshots from the helicopter." The police told the Farlam Commission of inquiry that these were stun grenades "aimed at dispersing the group of strikers" who were allegedly attacking police officers. Photo-journalist Marinovich (8 Sept. 2012) described the events in more detail, relying on accounts from Themba, a secondgeneration miner from the Eastern Cape, who was present as part of a group of some 30 strikers who were delegated to cross the veld (fields) that separated them from the Karee Lonmin mine. It was at this mine that other rock drill operators had led a wildcat strike to demand better wages, which the NUM had refused to support. Themba said 
the management took a tough line and many of the strikers had lost their jobs. The Marikana miners believed many of these miners "were still angry enough to join them". However, the Marikana strikers did not reach the Karee workers as mine security turned them back, setting them on a different route. It was on this road that they met a contingent of police. Themba described how the police with ten military-style Nyalas and one or two police vans blocked their way and told them to lay down their weapons. The workers refused, saying they were needed to defend themselves, as days before "three of their number had been killed by people wearing red NUM T-shirts".

The police line parted and they were allowed to continue, but once they were about ten metres past, the police opened fire on them. The miners turned and took on the police. It was here, that they killed two policemen and injured another, while the police killed two miners and injured a third severely, from helicopter gunfire, Themba said. (Marinovich, 8 Sept. 2012)

City Press journalist Tau gave the following account:

By the time we reached the scene about 45 minutes later, police officers were all over the place - some weeping, others gnashing their teeth while a few looked visibly traumatised. They had just witnessed their own colleague being hacked and stabbed. It was confirmed to us that the body count had risen from four to nine in just hours.(Tau, 13 Aug 2015, City Press.).

(viii) Photograph 8: Anti-mine armoured vehicles used by Police at Marikana

Photograph 8

see the Nyala: https://en.wikipedia.org/wiki/RG-31 Nyala

Caption: The Nyala is a robust anti-mine combat vehicle manufactured in South Africa. (Photograph Wikipedia, uploaded by David D Isakson)

Major General William Mpembe later told the commission how he had witnessed one of the two officers being "chopped and killed". (13 Aug 2015 City Press.) In retaliation, the 
police had shot and killed two men. Back at the housing area of Nkaneng, the journalists stood a distance away from the "dangerous men" on the hill, who could be heard singing and moving in small groups while most of them sat on the hill. "It was getting late and the mine security officials were not only warning us but would not let us go anywhere near Nkaneng informal settlement, let alone the hill." Tau said a few journalists who were there reluctantly decided to leave, unhappy that one-sided stories were filed in absence of any active voice from the strikers. (13 Aug 2015, City Press.)

As we drove off, we told ourselves that the following day we had to talk to the striking mine workers and get their side of the story despite the lurking danger. (Tau, 13 Aug 2015, City Press.)

Police spokesman Captain Dennis Adriano, when asked about the incident by telephone, said public order policing officers were attacked by miners, who hacked the two policemen to death and critically injured another.

The same day the body of a senior mine supervisor was found hacked to death on a footpath, a cow's skull left on his chest. There had now been eight other violent deaths: two mine security guards, two police officers and four mine workers who apparently had refused to join the strike. The eight had been hacked to death with pangas, stabbed with spears, shot and -- in the case of two security guards -- their bodies set alight. (Ledwaba, City Press, Aug 18, 2012). The Commission recommended that the National Prosecuting Authority ${ }^{35}$ investigate the five deaths on 13 August, those of two police officers and three strikers. (Nicholson, 26 June 2015, Daily Maverick).

Tau described that day in the following dramatic terms:

violence was sweeping through the little known mining town of Marikana... news was trickling in that the area had been plunged into total chaos; it was volatile and getting unstable by the minute... The next move then was to get the side of the story from the "dangerous men". (Tau, 13 Aug 2015, City Press.). 
What is most difficult to interpret at this point is the resistance of tribal workers carrying traditional arms, who faced antagonistic police armed with automatic weapons, and able to round them up using police vehicles and helicopters.

\section{b) Lonmin's role}

Because the NUM refused to support the strike by the rock-drillers, a key Lonmin director, Cyril Ramaphosa, who is also Deputy President of the South African government, termed the strike a wildcat strike and illegal in his terms, and the strikers "criminal" because of their bearing traditional weapons with threatening acts and attitude. These terms became justification for "tactical" action by the police who were summoned at the highest level.

The press seemed in every possible way to have a "hand-off" approach to Ramaphosa's role at Marikana in the phase of the shootings. However as time passed more account of his role as a Lonmin director needed to be aired.

A Daily Maverick investigation (24 Apr. 2013) revealed a furtive conflict of interest, with mining houses footing the bill for top National Union of Mineworkers office bearers' salaries. (Marinovich, 24 Apr. 2013). The investigation found that unionists were being paid high salaries by the very people from whom they are supposed to protect their members. Despite the pitfalls of conflicted interests, NUM had pushed the mines to pay unionists' salaries. "At the lower end, full-time shaft or shop stewards received a few thousand Rands extra per month to bring them to a pay grade of roughly R12,000 to R14,000 (US\$1,484-1,731)" a month. (Daily Maverick, 24 Apr. 2013).

In addition they received a company petrol card, company cell phone and a company vehicle. Then there were the other perks - or company get-togethers, international excursions, etc. The unionists were freed from the arduous labour and conditions that had encouraged them to join the union in the first place. (Daily Maverick, 24 Apr. 2013)

As this information became known to NUM members, many abandoned the union enraged, some joining the AMCU. On a number of occasions the leaders of the strikers sought an opportunity to talk to Lonmin management. Freelance journalist Jared Sacks 
published on 12 Oct. 2012, in Daily Maverick ${ }^{36}$ a timeline of events from Aug 8, when rock drill operators from various Lonmin mines held a mass meeting at which they formulated their new salary demand. This was one of the first reports using workers' accounts.

According to this timeline the NUM refused to support the strike and a day later the strikers were turned back by mine security when they tried to march on the Lonmin offices to make their new demand known. The NUM leaders present "categorically refused to support the strike, despite the union's stated mission to promote and represent the interests of its members." The following day, a manager and an NUM leader appeared together to reprimand the workers, saying they could only deal with management through the union. Xolani, a rock drill operator and striker from Lonmin's Karee mine, told Sacks that the strikers "came together as workers, not as a union." He describes how the large majority of the workers at the assembly were National Union of Mineworkers members, and that AMCU was unrepresented at this meeting. On the morning of Friday the 10th, workers assembled and again marched to the offices of Lonmin management. Sacks quotes David, a mine geologist employed by Lonmin who was returning from work, and had not been part of the strike, but then decided to join the strikers in order to find out what was going on.

David told me that management refused to speak to the workers, who were assembled peacefully, and told them to go back to the NUM leadership. Xolani and a few other participants in the march corroborated this. As a result of Lonmin and NUM's refusal to meet with the workers, more than 3,000 rock-drill operators (RDOs) and other miners decided to go on strike and refused to clock in that evening. This was a wildcat strike organised directly by workers, without any union representation (Sacks 12 Oct. 2012.)

The compromised situation of the NUM office holders would not only impact on the union but also on the Congress of South African Trade Unions (Cosatu), closely aligned with NUM since its launch in 1985 -- both union structures being at the heart of labour acting against the apartheid government. And in the light of the role Deputy President Cyril Ramaphosa played at Marikana, the consequences extend to Cosatu as part of 
the African National Congress (ANC) government alliance that also includes the South African Community Party. (See Chapter 4.)

\section{c) Internecine battle between NUM and AMCU.}

The government was called on by Lonmin and NUM to intervene to prevent inter-union rivalry, driven by the 'opportunism' of AMCU, from destabilising the mining sector. Large numbers of the strikers now showed no respect for the NUM, feeling abandoned by the union in their strike action and angry and resentful of the union playing a 'sweetheart role' with Lonmin. Some key members joined AMCU, which had gained a foothold in Lonmin's Karee mine where numbers of strikers were laid off. Five days before the major police shootings, the strikers marched to the NUM offices and two strikers were shot and killed by NUM officials who felt threatened. The same day 3000 rock-drillers and other miners decided to go on strike. They moved to the 'mountain' or rooikoppies (red hills) where they met each day. There was a rising antagonism between NUM and AMCU, as AMCU it took advantage of the resentment former NUM members felt towards their union officials. AMCU prepared to extend the strike action in the mining sector at large. This was a further rationale for the state to act against the strikers. I argue that this is secondary to the brutal violent episodes that led to at least 10 deaths before 'D-Day' August 16. These included NUM, the police, Lonmin guards and workers not identifying with the strike.

Sacks (12 Oct. 2012) conducted an investigation into the August 11, 2012 murders of two striking miners by NUM officials, that he believes was the start of the violence. $\mathrm{He}$ claimed neither death was reported in the media nor did they end in arrests. At about 7 a.m. on that day, workers decided to go to the main offices of NUM in Wonderkop and present the union leadership with a memorandum. Sachs (12 Oct. 2012) said it was important to note that the NUM offices were also the offices of the ANC and SA Communist Party in Wonderkop. They are manned by the top five NUM branch leaders from all the Lonmin mines in Marikana. These leaders were senior to shop-stewards and elected to their position by workers for a period of three years. As strikers were mainly NUM members, they were angry that their own union refused to listen to them. 
The memorandum demanded that NUM represent them in their call for a R12,500 minimum wage for all miners. (Sacks 12 Oct. 2012).

Julius, an RDO from Lesotho employed at Lonmin since 2008, explained to Sacks (12 Oct. 2012) that, as a NUM member, he was hoping the memorandum would convince union leaders of the significance of their wage demands. He said only a handful of AMCU members were present during that march, as many workers from the Karee mine, where the union already had a membership presence, were not yet participating in the strike in significant numbers.

Xolani, one of the few AMCU members present that day, said this protest was really a case of NUM members rebelling against their own leadership, and not a case of interunion rivalry. (Sacks 12 Oct. 2012.)

Sachs reported that as the striking workers were about 100-150 metres away from the NUM office, eyewitnesses, and participants in the march as well as informal traders in and around a nearby taxi rank, reported "without exception" that:

The top five NUM leaders and other shop stewards, between 15 and 20 in all, came out of the office and began shooting at the protesting strikers somewhere in the vicinity of the Wonderkop taxi rank. (Sacks 12 Oct. 2012.) Sachs said some strikers he interviewed claimed the NUM leaders first threw rocks at them before the shooting started. Others said they were attacked from two different angles of the taxi rank. There is also a discrepancy as to just how many guns were in the possession of the leadership that came out of the NUM office (reports range from between five and 15 firearms). Despite those discrepancies:

The witnesses claim NUM personnel shot at the protesters without warning or provocation. The miners were clearly ambushed by their union representatives. (Sacks 12 Oct. 2012.)

Sachs described how they ran in different directions and later re-assembled at Lonmin's football stadium then decided to move to a safer place, "the nearby koppie a small 
hilltop uniquely placed on public land between Wonderkop, Marikana and the various Lonmin mines." Sacks (12 Oct. 2012).

John, a non-striking Lonmin worker, saw two bodies of strikers not far from the NUM office as he returned home from work. Sacks said it was extremely difficult to confirm the names of the dead strikers as neither Lonmin nor the police would confirm two months after the incident that any deaths had occurred that day. However, a range of people Sacks interviewed corroborated the location of the two dead bodies. City Press reporter Ledwaba in his chapter Setting the Stage (Guns and Spears, Aug 2013) described how on hearing the rumour that two of their comrades had been shot and killed, strikers abandoned their rooms in the Wonderkop hostel and headed for the granite koppie (hill) outside the Nkaneng informal settlement. They were joined by other rock-drill operators living in Nkaneng and other informal settlements in the area. Ledwaba says the group eventually numbered about 3000 . They remained on the koppie for the next five days. They started singing a song with the following lyrics (translated from isiXhosa):

"We hate this NUM; how are we going to kill this NUM?" They punctuate their words by beating their weapons together. (Ledwaba, Aug 2013.)

Advocate Karel Tip, a NUM legal representative at the commission, later described this as an "extremely frightening experience for anyone associated with the union". Referring to these deaths, the Farlam Commission reporting nearly three years later, recommended that the NPA investigate two attempted murders on 10 August and the shooting of two strikers by NUM officials on 11 August. The commission also said that Lonmin should be investigated for knowing the risks but failing to protect employees regarding the killings of two security staff, two assaults, and the killing of a non-striking worker.

The ongoing conflict between the two competing unions, NUM and the new AMCU reached a highpoint on August 11, five days before the mass shooting, when union officials of the NUM fired on strikers filing past its office. The commission made a 
number of recommendations for the NPA to investigate and possibly prosecute, focusing on those who committed the killings rather than those in charge. (Nicholson, Daily Maverick, 26 June 2015).

\section{d) Collusion between government, Lonmin and the police.}

Several key observers have argued that the ANC Government sided with the mine owners against the workers' strike action at the Lonmin mine in Marikana. Together they called on the police to act against the workers in what became a premeditated massacre resulting in the deaths of 34 mineworkers. Academic researchers, Alexander (2012, 2013), Legassick (2012) and Gentel (2014a, \& b); as well as independent journalists Marinovich (2012), Sacks (2012), Fogel (2012); and Nichol $(2012,2013)$ as well as lawyers representing the miners at the Farlam Commission of Inquiry, have provided evidence of this collusion.

\section{ix) Photograph 9: Strikers armed with traditional weaponse) The build-up to the shootings}

Photograph 9

Caption: The strikers had fashioned strict rules governing the gathering: The militants were armed with pangas, spears, clubs and sharpened steel rods.

(Photograph by Gallo Images/Getty Images)

At Marikana the striking workers continued to carry arms. I argue that their refusal to give them up to the police became the real reason for the shootings, rather than the claim that the police were being attacked on Aug 16 as eye-witnesses to the Farlam Commission and the film Miners Shot Down prove. However the counter-attack of the strikers on Aug 13 that resulted in two policemen being hacked to death was no doubt fresh in the minds of all the policemen on the 16th; thus fear and anger/revenge would 
be a main factor for the shootings. The police at the Farlam Commission hearings over the past two years, were at pains to make known their series of very public yet unsuccessful attempts to get the strikers to disarm. Two days after the shootings, Lucas Ledweba (City Press 18, Aug 2012) described the build-up to the shootings. He interpreted a group that sat at the bottom of the hill flanked by thousands, as a hierarchy among the strikers, the more militant numbering a few hundred. He referred to the militant group as resembling disciplined warriors led by a tall dark man "draped in a green cape," identified as Mambush (Mgcineni Noki).

\title{
x) Photograph 10: Mambush leading the strikers carrying pangas
}

\author{
Photograph 10 \\ http://www.dailymaverick.co.za/article/2012-08-17-beyond-the-chaos-at-marikana-the- \\ search-for-the-real-issues\#.Vp-7z1J5 LM \\ Striking miners, carrying sticks, knobkerries, spears and pangas (machetes). Mambush \\ can be seen in the front row. \\ (Photograph by Greg Marinovich, Daily Maverick)
}

"If they want to kill us they may as well do so" said a man addressing the strikers as more police reinforcements arrived on the scene. (City Press, 18 Aug. 2012.)

The police had warned journalists that the strikers were hostile, armed and dangerous. Ledwaba then described a verbal exchange and deal made with the man in the green cape, who helped to make three volunteers available for interviews by the media. These interviews were carried out in front of the seated thousands with the strikers speaking through a loudspeaker. In the interviews, the strikers (all from the Eastern Cape) said their demand of R12,500 a month (US\$1,533), "was an all or nothing" issue for them. By midday on the day of the shootings it had become clear that the strikers were not going to leave the hill despite numerous attempts by the police and officials of the two unions, NUM and AMCU, "to negotiate a truce". (Ledwaba, City Press, 18 Aug. 2012.) 
Ledwaba adds that the AMCU speakers were at least "given an ear by the strikers", while the NUM speakers were heckled and forced to retreat. Ledwaba said:

It is becoming clear that the gathering was not going to end peacefully. (Ledwaba, City Press, 18 Aug. 2012.)

\section{f) 'D-Day' 16 Aug. 2012}

Malcolm Rees (16 Aug, 2012, Moneyweb) quoted a police spokesman who said: "We have tried over a number of days to negotiate with the leaders and with the gathering here at the mine, our objective is to get the people to surrender their weapons and to disperse peacefully. Today is 'D-day' in terms of if they don't comply then we will have to act ... we will have to take steps," he said.

A little later police spokesman Dennis Adriano said "Today is unfortunately 'D-day'. It is an illegal gathering. We've tried to negotiate and we'll try again, but if that fails, we'll obviously have to go to a tactical phase." (Marinovich, 8 Sept. 2012.)

In the light of the shootings on 'D-Day' this quotation signified terrible consequences.

Alexander in his work Marikana, turning point in South African history, (2013, p.608) found that Lonmin tried to absolve itself of responsibility, claiming that clashes were a consequence of competition between NUM and the new union, AMCU. The strike committee included members of both unions. "They rightly denied that rivalry caused the stoppage."

In the days leading up to the massacre, Lonmin lobbied government to treat the workers' action as criminal rather than as an industrial dispute thus justifying a police response along the lines proposed by Frans Beleni, NUM's general secretary that called for the deployment of the Special Task Force or the South Africa Defence Force. (Alexander et al 2012, 178). Three days later it was the task force that carried out the massacre. Alexander $(2013,608)$ described how Lonmin provided logistical support for the police that included offices for its Joint Operations Centre, intelligence collected by its security personnel, access to more than 200 security cameras, and accommodation, 
food and transport for the police. It donated helicopters used on the day, and provided ambulances and a detention centre. Alexander says the police task teams were armed only with automatic weapons "loaded with sharp ammunition, making it almost inevitable that workers would be killed. Indeed the police ordered four mortuary vehicles early on the morning of the killings, so they were expecting deaths to occur."

According to Bishop Jo Seoka (5, September 2012) who later brokered a settlement: "the massacre could have been avoided if Lonmin's management had listened to the workers' concerns." (Alexander 2013, 608).

Seoka's simple words resound with human concern from one who clearly believes in negotiation and proper communication.

Peter Alexander ${ }^{37}$, and two researchers interviewed witnesses in the days after the massacre. This enabled them to narrate "how the police planned and carried out the massacre at Marikana," published in the Socialist Worker, Issue No. 2317. (21Aug. 2012).

Strikers were surrounded by heavily armed police and soldiers, and killed while fleeing from gunfire. The state forces were not "protecting themselves". They participated in well-organised, premeditated slaughter." (Thapelo et al, 21 Aug 2012)."We interviewed surviving miners and looked at physical evidence on the site of the massacre. What we found is even more shocking than the story presented in the media."(Thapelo et al, 21 Aug 2012). They described how on the day of the killing about 3,000 striking miners were gathered on and just below the "mountain" (the hill or koppie). Joseph Mathunjwa, president of the AMCU, came and pleaded with them to leave to avoid a police attack. The miners refused. Within 15 minutes of Mathunjwa leaving, the police and army laid razor wire, separating the strikers from the Enkanini informal settlement, where many of them lived. Casspirs (armoured cars), horses and water cannon moved up to encircle the workers. (Thapelo et al, 21 Aug 2012).

Some workers had walked down to the razor wire to see if they could still get out through a gap. "Witnesses say police near the "small koppie" (hillock) opened fire on 
them, probably with rubber bullets. Some workers fled through a five metre gap in the razor wire. They were met with a barrage of live fire from the police and many died. Images of this shooting were broadcast around the world. (Thapelo et al, 21 Aug 2012).

Alexander describes how "the miners had been sitting peacefully on and around the mountain when the police reeled out razor wire in front of them, Fearful of being penned in, they began to leave the area, most walking northwards in the direction of Nkaneng, the nearby informal settlement where many of them lived."

Video footage shows that the workers were not running and not a threat to the police. It was at this point that the police started shooting. Only then did the men begin to run, but they were scattering, not charging at the police. (Alexander 2013, 608).

\section{xi) Photograph 11: The shootings at scene 1}

\section{Photograph 11}

http://qz.com/439222/how-to-understand-the-marikana-tragedy-with-south-africashistory-of-structural-violence/

Policemen fire at striking miners outside Marikana mine in Rustenburg, August 16, 2012. (Photograph by Siphiwe Sibeko, Reuters)

\section{xii) Photograph 12: Police weapons drawn over dying bodies}

\section{Photograph 12}

http://www.timeslive.co.za/sundaytimes/opinion/2015/07/05/Marikana-report-wastesa-chance-to-excise-festering-sores-in-SAPS

Heavily armed police still pointing their guns at the dead and dying as they stroll between the bodies after the first shooting at Scene 1.

(Photograph by Alon Skuy, Sunday Times)

Journalists sat in shock wondering if what they had just witnessed had really happened. 
Some of the men lay writhing in pain in the dust, their limbs moving slowly as they clung to life. But was it the actions of the men who charged at the police (who were armed) with their weapons and armoured vehicles? Why? Perhaps the answer lies in the statement made by Lieutenant-General Elias Mawela at a media briefing on Friday (Aug. 17)."We were dealing with people who looked possessed, or believed the bullets would not work on them." (City Press, 18 Aug 2012.)

Alexander's student interviewers described what followed:

Terrified strikers scattered in all directions, with a large number heading for cover by a koppie about 300 metres in the opposite direction from the wire. We identified this 'killing koppie' as where the largest number of strikers died". (Thapelo et al, in Alexander, 21 Aug 2012).

No cameras recorded this slaughter. But evidence remained four days after the massacre. There were remnants of pools of blood. Police markers showed where corpses were removed. "We found markers labelled with letters up to ' $J$ '. By Monday the whole area had been swept clean of rubber bullets, bullet casings and tear-gas canisters. We also saw patches of burned grass, which local workers claim are the remains of police fires used to obscure evidence of deaths." (Thapelo et al, 21 Aug 2012).

Other strikers were killed as they fled across the fields... Shots were fired from helicopters and some workers, heading for the hillock, were crushed by Casspirs. (Thapelo et al, 21 Aug 2012).

Photo-journalist Greg Marinovich (8 Sept. 2012.) in a two-week concentrated search on the site of the shootings at Marikana, found "that some of the miners killed appear to have been shot at close range or crushed by police vehicles. They were not caught in a fusillade of gunfire from police defending themselves, as the official account would have it." He said of the 34 miners killed at Marikana, no more than a dozen of the dead were captured in news footage shot at 'Scene 1'. 
The majority of those who died, according to surviving strikers and researchers, were killed beyond the view of cameras at a nondescript collection of boulders some 300 metres behind Wonderkop (identified as 'Scene 2'). (Marinovich, 8 Sept. 2012.)

He described how on one of these rocks, encompassed closely on all sides by solid granite boulders, is the letter ' $N$ ', the 14th letter of the alphabet. $\mathrm{N}$ represented the 14th body of a striking miner to be found by a police forensics team in this isolated place. "These letters are used by forensics to detail where the corpses lay." After examining the scene meticulously, he concluded that " $\mathrm{N}$ had no route of escape and had to have been shot at close range."

\section{xiii) Photograph 13: Greg Marinovich}

\section{Photograph 13}

http://www. dailymaverick.co.za/article/2012-08-30-the-murder-fields-of-marikanathe-cold-murder-fields-of-marikana

According to Marinovich, who investigated the sites months after the event, found the police marking on each rock where miners died."

(Photograph by Greg Marinovich)

In sites like ' $\mathrm{N}$ ', all four sides are hemmed in by rock. The letters signify murders at close range, in places hidden from plain sight. $\mathrm{N}$, for example, died in a narrow redoubt surrounded on four sides by solid rock. His killer could not have been further than two meters from him - the geography forbids any other possibility. Why did this happen? (Marinovich, 8 Sept. 2012.)

Other letters "denote equally morbid scenarios." $\mathrm{J}$ and $\mathrm{H}$ died alongside each other. "They, too, had no route of escape and had to have been shot at close range. None of these events were witnessed by media or captured on camera. They were only reported on as component parts in the sum of the greater tragedy." One of the striking miners caught up in the mayhem, referred to as "Themba" (though his name is known to the 
Daily Maverick), recalled what he saw once he escaped the killing area around Wonderkop. (Marinovich, 8 Sept. 2012.)

Most people then called for us to get off the mountain, and as we were coming down, the shooting began. Most people who were shot near the kraal were trying to get into the settlement; the blood we saw is theirs. We ran in the other direction, as it was impossible now to make it through the bullets. We ran until we got to the meeting spot and watched the incidents at the koppie. Two helicopters landed; soldiers and police surrounded the area. We never saw anyone coming out of the koppie. (Marinovich, 8 Sept. 2012.)

The soldiers he refers to were part of the police task team dressed in camouflage uniforms, brought to the scene in a brown military vehicle. Asked about this, Themba said he believed people "were hiding at the koppie, and police went in and killed them." In the days after the shooting, Themba visited friends at the nearby mine hospital:

Most people who are in hospital were shot at the back. The ones I saw in hospital had clear signs of being run over by the Nyalas. (Marinovich, 8 Sept. 2012.)

Marinovich said it became clear to himself that:

heavily armed police hunted down and killed the miners in cold blood. A minority were killed in the filmed event where police claim they acted in self-defence. The rest was murder on a massive scale. (Marinovich, 8 Sept. 2012.)

Researcher Botsong Mmope spoke to a miner, Tsepo, on Monday 20 August. Tsepo (not his real name) witnessed some of the events that occurred off-camera. "Tsepo said many people had been killed at the small koppie and it had never been covered (by the media). He agreed to take us to the small koppie, because that is where many, many people had died," Mmope said. After the shooting began, Tsepo said, he was among many who ran towards the small koppie. As the police chased them, someone among them said, "Let us lie down, comrades, they will not shoot us then. At that time, there were bullets coming from a helicopter above them." (Marinovich, 8 Sept. 2012 )

Tsepo then lay down. A number of fellow strikers also lay down. He says he watched Nyalas driving over the prostrate, living miners," Mmope said. "Other miners ran to the 
koppie, and that was where they were shot by police and the army with machine guns." When the firing finally ceased, Tsepo managed to escape across the veld to the north. (Marinovich, 8 Sept. 2012.)

The police narrative states: "following extensive and unsuccessful negotiations by SAPS members to disarm and disperse a heavily armed group of illegal gatherers at a hilltop close to Lonmin Mine, near Rustenburg in the North West Province, the South African Police Service was viciously attacked by the group, using a variety of weapons, including firearms. The Police, in order to protect their lives and in self-defence, were forced to engage the group with force. This resulted in several individuals being fatally wounded, and others injured."

This police statement clearly states that the police acted in self-defence, despite the fact that not a single policeman suffered any injury on 16 August. (Marinovich, 8 Sept. 2012.)

Marinovich found that the weapons used by most of the 400 police on the scene were R5 (a licensed replica of the Israeli Galil SAR) or LM5 assault rifles, designed for infantry and tactical police use. He added that they were not designed to fire rubber bullets.

The police were clearly deployed in a military manner - to take lives, not to deflect possible riotous behaviour. The death of their comrades three days previously set the stage for the police, who have been increasingly accused of brutality, torture and death in detention, to exact their revenge. (Marinovich, 8 Sept. 2012.)

Marinovich in referring to the need for revenge on the part of the police, says "what is unclear is how high up the chain of command this desire went." He notes the "police obfuscation and selective silence" referred to by lawyers in the Commission hearings, adding that in a democratic society where the police are, theoretically, accountable to the citizenry, and to elected representatives, "We live in a country where people are assumed innocent until proven guilty; where summary executions are not within the police's discretion." He concludes: 
Let us be under no illusion. The striking miners are no angels. They can be as violent as anyone else in our society. And in an inflamed setting such as at Marikana, probably more so. They are angry, disempowered, feel cheated and want more than a subsistence wage. (Marinovich, 8 Sept. 2012.)

\section{g) The Police case}

Ishmael Semenya, representing the police, appeared before the Farlam Commission on 23 October 2012 for the first time, and argued that the police had acted under extreme duress and the threat of death when they shot the miners. He presented a picture of a pitched battle. Numerous attempts "to peacefully disarm the miners" had been made, he said, but to no avail. "They had refused and proceeded to the koppie, killing two police officers and seriously injuring one (on Aug. 13). They also robbed the police officers of two pistols, an R5 rifle, a shotgun, two-way radio and ammunition. Teargas, stungrenades and rubber bullets were used to disperse the protesting miners. None of these measures had deterred the protesters." Two days before the shooting police had been in negotiations with the mineworkers, and had asked them to disarm.

Semenya said that the circumstances of Marikana were unique, in that "the police had never been forced to deal with thousands of armed men who charged at them, seemingly with complete disregard to their own lives." (Hlongwane, 23 Oct. 2012, Daily Maverick.) George Bizos, acting for the Legal Resources Centre, almost immediately contradicted Semenya. He said he would introduce evidence that would show the shootings were an act of revenge by the police for the deaths of two colleagues some days earlier. He said that the Constitution, legislation and common law do not permit murder as an act of revenge. The Legal Resources Centre did not come across a single piece of evidence showing that any police suffered so much as a scratch on 16 August, which flies in the face of the claim that they acted to protect their own lives. He also said the use of lethal force by the police was not only unlawful, it was also unheard of historically. "We are going to call in experts to prove that what the police did on August 16 is unheard of in the whole world. We are going to ask for permission to crossexamine those who gave permission," he said. "If you have 3,000 protesting people on 
one side, some of them armed, and you turn R5s and R6s on them, that is unique and historically that is incorrect." (Hlongwane, 23 Oct. 2012, Daily Maverick.)

Dumisa Ntsebeza, who represented the families of 21 dead miners, said, "We will invite the commission to make the finding that the miners were unlawfully killed by the SAPS." He said he intended to introduce evidence directly contradicting the police version of events. Ntsebeza said he was upset at the way the police advocate kept referring to the potion the men took before the deadly confrontation. "The miners were considered to be possessed vermin which... had to be destroyed like vermin by police and they... were killed like vermin." (Hlongwane, 23 Oct. 2012, Daily Maverick.)

Karel Tip, representing NUM, highlighted the death of local NUM Secretary Daluvuyo Bongo as just one of the examples that his team would use to show the striking miners' total disregard for the rights of other people, especially NUM members and leaders. $\mathrm{He}$ said the union would argue that the use of force by the police was justified. (Hlongwane, 23 Oct. 2012, Daily Maverick.) This statement by Karel Tip was made when the Farlam Commission of Inquiry hearings began on October 1, 2012.

\section{h) Findings of the Farlam Commission}

In announcing the commission's main findings and recommendations, President Zuma said he had written to Police Commissioner Phiyega about the findings. He said the commission had exonerated Deputy President Cyril Ramaphosa of blame for the incident. "The commission has found that it cannot be said that Mr Ramaphosa (a Lonmin director and Deputy President of the ANC) was the cause of the massacre," adding that such claims had been found to be "groundless". It found that the "(Lonmin) executive played no role in the decision of the police to implement the 'tactical option' on 16 August 2012". He referred to the 'tactical option' that had required the encirclement of strikers and their disarming, "but this plan should only have been implemented when there were few strikers on the scene." "The 'tactical option' was defective in a number of respects. The police operation should not have taken place on 16 August because of defects in the plan." Zuma said the commission found that "the decision that the strikers 
would be forcibly removed was not taken by the tactical commanders." He said the operation should have been stopped after the shooting at 'Scene 1'. Instead it went ahead and "There was a complete lack of command and control at 'Scene 2'. It had been found that the police had misled commission about when the decision was taken to use the tactical option." (RDM Online, 25 June, 2015.)

Journalist Niren Tolsi (2015), writing in the Mail \& Guardian on July 2, reported that "the Commission found that lies and obstructionism characterised the police's approach to evidence disclosure." He reflected how in an 18 month period the South African Human Rights Commission "had asked the police repeatedly for documents more than 50 times, to be told they did not exist nor could they be located. When commitments were made to make documents available the SAPS still failed to so." He said the report had raised "serious concerns" about medical assistance only arriving an hour after miners were shot dead at Scene 1 and found that the police's tactical operation should have been stopped after the seventeen deaths there. "Instead, police continued to "Scene 2" where they killed a further 17 miners who, forensic evidence suggested, were killed execution-style, and according to the reporters four of the men had bullet wounds in the head or neck while 11 men had been shot in the back. Tolsi and Mail \& Guardian's chief photographer, Paul Botes, in "Marikana: The Blame Game" (June 2015) after President Zuma's broadcast, described some of the evidence laid before the Farlam Commission :"The world reacted with horror to televised images of South African police firing an eight-second fusillade at striking miners at Marikana, in the North West province, killing 17 of them." They found that none of the police leaders on the ground provided justifiable reasons for not halting the "tactical operation" after this shooting at 'Scene 1'.

Police evidence presented to the Farlam Commission shows the scene of the killings at Marikana. The Big Koppie (rocky hill) is where the miners met daily during the strike; Marikana 'Scene 1' is the cattle kraal (cattle pen) where the first 17 miners were killed by police; and Marikana 'Scene 2' is the koppie (small hill) where miners ran to for refuge, but another 17 were also shot here by police. (Mail \& Guardian, The Blame Game). They explore evidence before the commission that strongly suggested that 
another 17 miners, "who posed no threat to the police, were executed by police away from television cameras at 'Scene 2'" after the first fusillade. There "police members fired 295 rounds of live ammunition at hundreds of miners hiding on the koppie, where they had run for refuge after witnessing the earlier slaughter." Evidence before the Commission had suggested that the police had fired with intent and purpose at the koppie. Nine miners "were shot like fish in a barrel while hemmed in a natural enclosure among the rocks. Most were shot dead while hiding in the undergrowth, forensic investigations confirmed. Four had bullet wounds in the head or neck; 11 had been shot in the back. Some mineworkers put their hands in the air to show they weren't fighting/attacking the police officers but they were shot."

Striking miner Siphete Phatsha said police seemed to be hunting them down: "I could see police coming into the bushes and shooting at people hiding there. Where I was hiding, they couldn't shoot at me, but I was waiting to die. ...I stood up with both my arms in the air and the first shot hit me in [the right side of] my chest. The next one hit me in the [left] shoulder and the third in my [fore-] arm," said Nova. He was shot eight times while surrendering. The police killings at 'Scene 2" also extended to the planting of weapons on at least six dead miners, the Farlam Commission heard. Pathologists described in detail the injuries of the dead, at times suggesting how individual miners may have been saved if given medical attention after the shootings.

In examining why the press was missing through great parts of the Marikana shootings story, I will focus on the practice of journalism and decision-making in the news process, that includes Jane Duncan's commentary on "pack journalism" and how the media follow each other's leads in finding sources of news especially when they come late onto a story. It is evident in news events such as a strike or conflict situation that require immediate levels of decision-making, that some media are better prepared than others to step into the situation. This often requires team work and staff at both ends -- the scene of the event or action and at the office desks and dark room where the information is processed. 
Often in a big news story just one or two wide-awake journalists, be they reporters or photographers, seize the moment to get the story in advance of everyone else. What is interesting about the coverage at Marikana is that the best reporting and pictures came from a small group of individuals seemingly working separately. The most impressive team work came from City Press, Daily Maverick, Business Day, and Mail \& Guardian and one outstanding coverage of 'D-Day' by The Star.

The commission recommended inquiries into the fitness of National Police Commissioner Riah Phiyega and North West Police Commission Zukiswa Mbombo to hold office. "The leadership of the police, on the highest level, appears to have taken the decision not to give the true version of how it came about that the 'tactical option' was implemented on the afternoon of 16 August and to conceal the fact that the plan to be implemented was hastily put together without [public order policing] inputs or evaluation," reads the report. Phiyega was regularly evasive under cross-examination, but the report does not seem to implicate her in the killings. (Nicholson, 2015).

Nicholson, writing in the Daily Maverick (26 June 2015), described how at 'Scene 1', where the strikers were killed on camera, the commission found that the police "effectively closed off a gap that channeled the mineworkers towards the Tactical Response Team (TRT) while it could have boxed them in." The police had failed to use non-lethal weapons effectively, and when they did the teargas and water cannons had the effect of further pushing the miners towards the TRT.

The officers who opened fire with live ammunition felt a reasonable risk to their lives, the report says, but four people were killed who clearly presented no threat. (Daily Maverick, 26 June 2015).

At 'Scene 2', dubbed the "killing koppie" by some observers, the Commission found, "The lack of clarity around the death of the 17 deceased persons at 'Scene 2", places the Commission in the difficult position of not being able to make findings as to the circumstances surrounding the death of each deceased. To accept or reject any version, with any degree of certainty, requires further interrogation of many factors." 
Nicholson reports that no cartridges found at 'Scene 2' that could have been fired by the miners, while at 'Scene 1' there was one shot fired by the miners caught on camera and one other gun recovered without a full round in the chamber. The commission was not convinced by the SAPS scenarios of what might have happened at 'Scene 2'. "Apart from the evidence of a reconstruction of the scene by [policing expert] Mr De Rover, the South African Police Service provided no details of what happened with regard to the deaths of most of the deceased at 'Scene 2'. Where it does provide evidence pertaining to the deaths of some of the deceased, their versions do not, in the commission's view, bear scrutiny when weighed up against the objective evidence." (Nicholson, Daily Maverick, 26 June 2015).

In a commentary in Ceasefire, an online independent political and social commentary website, Benjamin Fogel, argues that the killing resulted from the government intervention which was prompted by the need (1) to placate the fears of foreign investors about the economy; (2) to prevent inter-union rivalry, from destabilising the mining sector; (3) to prevent the irrational mass driven forward by 'witchcraft' from going further; (4) to prevent Malema and his allies from using the miners in a insurrection against the government (Fogel, 5 Nov. 2012).

In an unexpected twist to the shootings, the police arrested and charged 270 miners in the days and weeks following the police shooting suggested that the police were trying to deflect their responsibility in the killings. Two days after the shooting they brought charges against 259 people and trucked them to various police holding cells in the North West province and Gauteng, according to Sipho Hlongwane of the Daily Maverick (4 Sept. 2012). However, by the beginning of September 2012, the number of arrests had increased as police scouted the squatter camp and hospitals near the site of the shooting to collect miners who were at the scene. The National Prosecuting Authority had decided to charge the 270 arrested men with murder and attempted murder under the "common purpose" provision. This twist in events was described by lawyer Pierre de Vos, in this blog Constitutionally Speaking, as "bizarre and shocking and represents a flagrant abuse of the criminal justice system." Numerous complaints alleging that police 
were torturing the arrested men were filed with the official police watchdog, the Independent Police Investigative Directorate (IPID), according to the Daily Maverick (Hlongwane, 4 Sept 2012), As many as 150 workers claimed they were beaten while in police custody (Poplak, Daily Maverick 4 Sept. 2012). The folly of their actions became patently clear when the strikers were released from custody on September 3, by the court following a decision by the NPA that the doctrine of "common purpose, common design, joint enterprise, or joint criminal enterprise" -- terms in common law legal that indicate liability -- were misappropriated in this instance.

Ironically, it was the apartheid state had used these provisions in the criminal law to convict people that were not event present at a crime. Laing, 3 Sept. The Telegraph, London). South African lawyer Jay Surju told the BBC's Focus on Africa programme that the "common purpose" doctrine was used by the former white minority regime against activists fighting for racial equality in South Africa. "This is a very outdated and infamous doctrine discredited during the time of apartheid." The best known case was that of the "Upington 14", who were sentenced to death in 1989 for the murder of a policeman in 1985. In the trial, 14 activists were convicted of murder, even though the trial judge had acknowledged that they did not carry out the killing. The police shootings at Marikana, the wrongful arrest and spurious charges laid against the miners, caused more harm to the police case. The credibility, judgement and capacity of the police came into question increasingly, and dealt with in great detail by the Farlam Commission.

The Commission recommended that the NPA investigate the shootings in scene 1, that by police who "may have exceeded the bounds of self and private defence "(Daily Maverick, 26 June 2015). The Commission expressed concern that commanding officers might still be held liable for a) the delay in conveying medical assistance to the miners that were shot at scene 1 , and $b$ ) that they lost control of the police in their charge at scene 2 (Nicholson, Daily Maverick, 26 June 2015).

The Farlam Commission findings, which were released to President Zuma on the 31st of March 2015, but only released to the public by the President on 26 June, recommended that expert ballistic and forensic pathologists conduct a final summary of 
the police conduct at Marikana, Calling for a "full audit trail and an adequate recording of police operations", the Commission commented that the SAPS and its members should take responsibility for its actions. Recommendations were made concerning future policing of protests and called for best practice reviews and training to improve the police's capacity of managing civil protest.

In my critique of the media it is clear from the initial coverage of the shootings that there are were serious deficiencies in the news gathering process. Fogel (5 Nov.2012) finds that a hierarchy of views about what actually happened emerged in the public domain. One version of events, "which seems to be the version borne out by the television and most journalist accounts, particularly the Sunday papers, effectively pointed to the striking workers having precipitated the fatal shooting by effectively firing on the police first." Later media reports alleged that the miners were driven to their 'suicidal charge' by the belief that muti provided to them by traditional healers rendered them invulnerable to police bullets. Other coverage suggested that the former African National Congress Youth League president Julius Malema whipped up miners into a murderous frenzy. Fogel refers to the survey of media reports by academic Jane Duncan that revealed that only $3 \%$ of the reports on the massacre actually included the views of the miners, instead focusing on 'expert' opinion in the form of economists, Lonmin management and other elite representatives. Furthermore these narratives consistently referred to the strike as 'illegal' and 'criminal' in the media. This is despite the fact that wildcat strikes are not illegal according to South African law. They are 'unprotected', allowing employers to fire workers taking part in a wildcat strike.

Fogel (5 Nov. 2012) says much later reporting, particularly that by Greg Marinovich of the Daily Maverick (30 Aug 2015), "indicated that the 'official story' of the Marikana massacre was an utter distortion of what actually occurred, despite the large presence of journalists at the scene of the massacre." He says Marinovich demonstrates that about half of those killed on the 16th of August (17 workers), were shot in the back and many were killed at the so-called second kill zone ('Scene 2'). Witness reports collected by Marinovich have indicated that many of those killed at 'the small koppie' "were 
executed in Cold Blood." The strike at Marikana lasted over 6 weeks ending in a settlement of a reduced wage demand between the striking miners at Lonmin.

Marinovich was ideally placed to develop a critique of the media being a foremost independent photojournalist on scene at Marikana from the start and still writing about it three years later. Commenting on the value of photography in recording the shootings, Marinovich said the toll of 112 mineworkers (34 dead and 78 wounded) at Marikana:

is one of those few bitter moments in our bloody history that has been captured by the unblinking eye of the lens. Several lenses, in fact, and from various viewpoints. (Marinovich, 8 Sept. 2012).

He describes how photography allowed the actions and reactions of both the strikers and the police "to be scrutinised in ways that undocumented tragedies can never be... Therefore, while the motives and rationale of both parties will never be completely clear, their deeds are quite apparent. Thus developed a dominant narrative within the public discourse." Marinovich gets to the nub of the controversy as to what finally provoked the police shootings. He argues that various images and footage can be read to support the claim based on facts fed by the police and various state departments and taken up by the media, that the strikers provoked their own deaths by charging and shooting at the forces of law and order.

The contrary view is that the striking miners were trying to escape police rubber bullets and tear gas when they ran at the heavily armed police task team (our version of SWAT.) $)^{38}$ The result was the horrific images of a dozen or so men gunned down in a fusillade of automatic fire." (Marinovich, 8 Sept. 2012.)

\section{Conclusion}

The real stuff of battles of this sort is seldom reported succinctly and cannot be explained in neat rational explanations. It has taken three years, including a commission of enquiry, to reconstruct much of the events that resulted in the shootings. During this time a media narrative has emerged that suggests that the violent behaviour of the striking workers in the days preceding the shootings, especially of the killing of two 
policemen hacked to death, resulted in the police taking revenge. Clearly there is a moral incentive to avoid such an 'opportunity', by keeping the police under control. Grave concern was expressed by the Farlam Commission that the police went out of control after the scene 1 shooting where they had literally mowed down 17 of the strikers brandishing their traditional weapons. The lack of control and command resulted in scene 2 where workers were trapped, out of the eye of reporters, and killed.

In conclusion, the media was underrepresented on the day of the shootings. They had not been diligently following through on the violent events of the preceding week, especially the killings of the police, the Lonmin guards, and fellow workers who were strike breakers and the shooting of two of the striking workers by NUM officials --the events that preceded the shootings by the police. Similarly, the earlier reportage of the development of the strike reflected a shortage of beat reporters in following the strike or the production failures at the mine, suggesting a failure news organisation of pulling together these various strands that were leading to the buildup. Both Duncan (2013) and Fogel (2012) refer to the borrowing of stories by the media from the few active journalists on the scene, and how this failure resulted in most of the news reports reflecting mainly institutional sources such as quotes from the police, the companies and government authorities, and few if any, firsthand accounts by workers. The exceptions were photojournalists, Marinovich and Sacks, and then gradually the Daily Maverick, City Press, Mail \& Guardian and Business Day. Not only is this an indictment of the press in the new democracy, but a huge let down of the legacy of the press that remained vigilant of police brutality in final years of apartheid. 


\section{CHAPTER 5: MARIKANA AND THE NEW POLITICS OF LABOUR}

The Marikana shootings were a turning point in South Africa's post-apartheid history, when wildcat strikers were ambushed by South African police and 112 miners were shot and 34 killed. There is evidence to suggest the shooting was orchestrated between the state and big business. Congress of South African Trade Unions (Cosatu) the major labour federation, failed to represent the interests of the working class. This chapter argues that Cosatu lost touch with the interests of the working class, becoming largely a white collar union representing salaried and government employees (Gentle, 2014b). Because of its ties to its Alliance partners the African National Congress (ANC) and the South African Communist Party (SACP), Cosatu had already become moribund by the time of the strike at Lonmln by platinum mineworkers. Cosatu's inability to side with striking workers before the Marikana massacre and to prevent a security alliance developing between capital (Lonmin) and the state (ANC) was clear, and led to the split in Cosatu and the breakaway of the National Union of Metalworkers of South Africa (Numsa). Marikana became the fulcrum of the class struggle and a defining moment in the relationship between the Alliance partners in government, Cosatu's loss of relevance to labour, the SACP's loss of intellectual leadership, and the ANC's loss of the working class as its power-base. This combination could cost the ANC its commanding position.

This narrative emerges from the media coverage on the trade unions and the implications of the Marikana events for labour. The best media to cover the union story are Mail \& Guardian, Business Day and the online Daily Maverick with some in-depth reporting from The Guardian of the British press. The main critique of the media is the failure of mass circulation newspapers, such as City Press, and The Sowetan, and national radio to employ dedicated journalists who are beat reporters in the labour sphere and who monitor the interaction between the trade unions and industry. 
Further, the media failed to articulate the indictment of the ANC tripartite Alliance (ANC, SACP and Cosatu) in the police shootings of striking workers, termed a massacre. What was missing, and still is, three years after the shootings, is the failure to hold the "liberation movement" ANC accountable, with the implication that it should no longer be in government, or at least its leadership could or should have been depleted as a result of Marikana. Part of the failure of the media was its unquestioning reporting of Cyril Ramaphosa, the Deputy President, a key board member of Lonmin, and a player in the whole Marikana episode, who stigmatised the strikers as 'criminal' and freed of all responsibility of the actions of the police, by the Farlam Commission when it reported in June 2015.

\section{a) Cosatu in crisis: loses its dominance}

Although Cosatu represented the most powerful union federation, by the time of Marikana, socio-economic dynamics had weakened its dominant position. These dynamics included the lengths to which the ANC was prepared to go to demonstrate its support for the mining houses, and the dominance of the mineral energy complex $(\mathrm{MEC})^{39}$ in capital accumulation. AMCU and the National Union of Metalworkers (Numsa) positioned themselves in the mining arena to get the support of the striking platinum workers, further undermining of Cosatu's prominence. Sam Ashman and Nicolas Pons-Vignon (2015) considered the general predicament of the miners was poor pay and working conditions and the reproduction of the 'classic' migrant labour system of the 1920 s to the late $1970 \mathrm{~s}^{40}$. These factors combined with general failures in social and economic provision of housing, health and education across the mining areas. In addition to the crisis in Cosatu was the failure of its National Union of Mineworkers (NUM) to contest the shareholder-driven accumulation of the mining houses that had led to an explosion of resentment and the rapid rise of AMCU. At the centre of the exchanges between Lonmin management and the ANC and in a total reversal of his former role as former leader of the country's major trade union federation, was Cyril Ramaphosa, the Deputy President of the ANC now a major Lonmin shareholder, said to be a billionaire (Ashman \& Pons-Vignon, 2015). 
Cosatu has been weakened by the difficulties of socio-economic transformation in South Africa and the intensification of popular struggles over current conditions. The changing politics of the labour movement in South Africa is described as one of "restructuring" (Gentle, 2014a; Ashman \& Pons-Vignon 2015). Cosatu has changed in composition from a largely blue-collar working class formation in the 1980s and 1990s to the largely public sector, white collar federation that it is today (Gentle 2014a). An example of this shift is seen in the composition of the National Union of Mineworkers (NUM) Cosatu's largest member, from being a union of coal-face workers to a union of white collar, above-ground technicians (Gentle, 2014a).

The much larger-than-expected political shift that has occurred includes the rise of the Economic Freedom Fighters (EFF) that is described as a revolutionary socialist political party to the left of the ANC. Its success in the 2014 elections was described as "astounding" when it won a million votes $(6 \%)$ and 25 seats in parliament only eight months after its launch by former ANC Youth League leader, Julius Malema (Gentle, Aug. 2014b).

In this period the neoliberal attacks on the working-class have involved a shift away from full employment and fixed employment toward casualisation, informalisation and unemployment. (Gentle, 2014a). Gentle argues that commentators from the right describe Cosatu unions as having been too political, sacrificing workers interests for political gain. They call for unions to "go back to basics" - meaning, to focus on 'pure' collective bargaining and the servicing of members. On the left, the analysis is that Cosatu has adopted the wrong politics - in kowtowing to the ANC's neoliberal policies. In this view it is not a problem of Cosatu being too political, but not being political enough. From these quarters the answer is that if Cosatu were to embrace revolutionary politics then the problem of worker disaffection would be solved (Gentle, 2014b). Or would it? In the year 2015 one asks what would embracing revolutionary politics mean $?^{41} \mathrm{~A}$ more modern concept of revolutionary politics would need the same combination of a mass movement with its own military power. 
Sharp (2014) argues that a generational change in attitude towards collective bargaining has resulted in young people preferring to negotiate their wages and working conditions individually. Union membership as a proportion of the national workforce has declined from $45.2 \%$ in 1997 to $25.4 \%$ in 2014 . There are now more union members in the public sector than in the entire private sector put together (Sharp 2014). In addition, the working class has been rapidly declining while the black middle class has been rapidly growing. In 1994 there were 1.8-million people in the black middle class; by 2014 it had grown to 5.9-million. This extraordinary change is partly a result of the Black Economic Empowerment (BEE) policy in both the public and private sectors, large-scale employment of blacks at every level. A consequence will be that the middle-class will vote with its feet in national elections, and that the ANC could lose the major economic hub, Gauteng province, to the Democratic Alliance in 2019 (Sharp 2014).

The challenge for the ANC is whether to follow the dwindling working class, as it is currently doing, or to embrace the emerging middle class, which will involve a complete turnaround in its political and economic agenda. (Sharp 2014).

\section{b) The rise of the Black middle class and the dynamics of labour}

Already the middle class, white and black, is more numerous: 10.5-million white-collar workers to five million blue-collar workers. (Sharp, 2014). There is, of course, "the vast sea of unemployed people (7.7-million), who swing the ANC's electoral calculus in favour of the working class" - but only just. Historically, both the ANC and the trade union movement leadership were strongly influenced by, and made up of, Communist Party members. However, in the transition to power, ANC economic policy came under the control of Deputy President Thabo Mbeki, who came under the stronger influence of the World Bank and the International Monetary Fund as well as South Africa's largest capitalist corporations. The result was that South Africa adopted neoliberal market policies (Gentle 2014a; Vavi 2014). Against this shift, Cosatu advocated a Reconstruction and Development Programme (RDP) in the 1990s running up to the first democratic election. Based on a transformation agenda, it was formally adopted by the tripartite Alliance of the ANC, Cosatu and the SACP. However, taking its place in 1996 
was the ANC's Growth, Employment and Reconstruction (GEAR) macroeconomic program. This constituted a range of policies and processes within the labour relations system that undermined the working class (Vavi 2014). GEAR's policies included privatisation of all major state enterprises, the adoption of conservative policies on exchange control and inflation, and a rapid reduction of protective trade tariffs. There is extensive evidence demonstrating the influence the World Bank and the International Monetary Fund (IMF) had on ANC economic policies in the period from 1992. "Thabo Mbeki in particular would have no truck with anything that could vaguely be construed as Eastern European socialism or its African equivalent." (Gumede, 2007)

Massive casualisation and restructuring of the working class as a result of the introduction of the concept of labour brokering led to the loss of 1 million, private sector jobs in the period 1996 to 1999 (Vavi 2014). Cosatu called its first post-apartheid major general strike in May 1999 in protest against these policies and their impact on workers and the working class in general. There followed several public policy exchanges with the ANC in the ensuing years. At the 52nd conference of the ANC at Polokwane in 2009, a number of resolutions were adopted which Cosatu believed would chart the way forward to a new radical economic agenda that, again, "never saw the light of day" (Vavi 2014).

In a political report at its 11th Congress in 2012, Cosatu urged that a radical break with the past was required in order to propel South Africa into a "Lula Moment"42 where poverty, inequality and unemployment would be addressed head-on (Vavi, 2014). Due to the failure of the facilitated process that followed the congress, nine affiliated unions demanded another special national congress to resolve areas of policy differences. This group, the right wing of Cosatu, successfully voted for Vavi's suspension for eight months ${ }^{43}$; the appointment of an ANC Task Team to report on Cosatu; and the expulsion of the National Union of Metalworkers of South Africa (Numsa), on November 7-8, 2012 after a vote of 33 to 24 of Cosatu's central executive committee.

An economic cause of the Cosatu-Numsa divide is identified as a decline of the primary agricultural and mining sectors and the emergence of the vibrant financial services and 
retail trade sectors.(Ashman and Pons-Vignon p. 99). In the 20 years from 1994 to 2014, agricultural employment fell from 2.5-million to 686000 workers; and mining from 1.4-million to 441000 (Sharp, 2014).By 2014 the financial sector employed 2-million and the retail sector 4.1-million workers. A major consequence has been a rapid increase in the cost of organising workers (Sharp, 2014).

\section{d) 'Numsa's Moment' -- the break with the ANC and other fall-out}

The resolutions adopted at NUMSA's Special Congress in December 2013 "marked the most important rupture in South African politics since 1994" (Ashman \& Pons-Vignon, 2015, p.95). The union refused to endorse the ANC in the election. It called on Cosatu to break away from the Tripartite Alliance and it resolved to organise a new United Front to coordinate struggles in the workplace and communities and to explore the establishment of a new Movement for Socialism. This 'rupture' or event is referred to as the 'Numsa Moment'. (Ashman \& Pons-Vignon, 2015, p.98). The question raised by these events is: "Can either Numsa or Cosatu succeed in rebuilding working-class unity in a context of growing fragmentation?" Much of this detail of what was happening to the unions and Cosatu was missed by the media.

Sosibo (12 Oct. 2012), writing for the Mail \& Guardian, provided a sense of labour's "growing fragmentation" between the trade unions and workers choosing to be independent of the union. In describing the situation two months after the police shootings at Lonmin he refers to how a "violent implosion" appeared to be building up increasingly in the platinum belt where an estimated 100000 miners were now on strike. NUM's membership at platinum companies Amplats and Lonmin had dropped by an estimated 20,000; and at Implats its membership had dropped from $70 \%$ to $13 \%$. And within the year to date, 13 NUM shop stewards had been killed, many of them assassinated. He reported damage to property and escalating violence in the previously calm Amplats strike. He said the Amplats management had told NUM that it had dismissed 12800 employees, 7000 of whom had made representations and were "finding ways of going to work", understating the dangers such workers would face as strike-breakers or scabs. Simon Neville, writing for The Guardian (5 Oct. 2012), 
described how Amplats workers demanded higher salaries, claiming that rival firm Lonmin had set a precedent a month before by giving its staff a $22 \%$ pay rise after weeks of unrest and the police shootings. Amplats refused to offer a pay rise similar to Lonmin's, although the chief executive, Chris Griffith, suggested that a salary review due the next year could start earlier. Neville reported that Anglo American was considering closing some of its South African mines following the suggestion by Credit Suisse analysts that the company could shut two or three of its five operating shafts.

In spite of the presence of Cosatu and the SACP in the ruling coalition, workers are losing ground in the class struggle in South Africa" (Ashman \& Pons-Vignon 2015, p.102).

Besides the battles between competing unions, the context is one of high unemployment, extensive labour casualisation, and ongoing protest over service delivery and waves of workers' struggle, with inequality endemic. "Ebrahim Harvey (17 Jul 2015), writing for the Mail \& Guardian in the week of Cosatu's annual congress, says: "Over the years, bitter factionalism has torn at the labour federation and caused deep fissures." He says "Cosatu has not been much more than convenient electoral fodder for the ANC for 21 years, which is a long time given the huge expectations Cosatu members had in 1994." He says his criticism is especially relevant because the black working class, "especially organised labour, was regarded as the motive force of the National Democratic Revolution". This led to legitimate expectations that black labour would be the biggest beneficiary after 1994. He says that since the global economic crisis of 2008, "the triple scourges of unemployment, poverty and inequality have worsened: We have for a while now been the most unequal society in the world, a most devastating indictment of ANC rule since 1994. (Mail \& Guardian 17 Jul. 2015). The failure of Cosatu to be responsive to the identity and needs of the working class has had dire consequences from which it may never recover. Harvey says there was little prospect of preventing a split in Cosatu, especially as Numsa was now firmly moving along "a fundamentally different trajectory to form a socialist workers party in direct opposition to the ruling ANC, a process that is now unstoppable." 
Among challenges that Numsa will face is how best to raise support while capital and the Alliance partners will do everything possible to isolate and discredit it. Its ability to build a socialist movement "will hinge on the success of its grassroots mobilisation of workers but will also depend on the alliances it will forge with those social movements disillusioned with the ANC and other unions" (Ashman \& Pons-Vignon, 2015, p.106-7). If Numsa's expulsion from Cosatu holds, the response of the other unions on the left will be critical, as will the stance of Cosatu's general-secretary Vavi. "Should the Numsa initiative fail, the left in South Africa is likely to be put back decades (Ashman \& PonsVignon, 2015, p.113)". ${ }^{44}$ Sharp concludes that the Numsa-Cosatu split is much more complex than it at first appears. She describes it as "a battle for the heart of the ANC" (Sharp 2014).

'Numsa's Moment' to break with the ANC and Cosatu was a turning point for South African labour and the working class in response to the ANC's abandonment of both, when it collaborated with Lonmin to prevent a strike that resulted in the Marikana shooting. Now there is a testing time to see whether Numsa will be able to win back a working relationship with Cosatu, or the SACP (Ashman \& Pons-Vignon, 2015, p.111). One of the threads in this narrative is picked up by Munusamy, (Daily Maverick, $15 \mathrm{Jul}$. 2015) who believed Vavi and Numsa's plan to return to Cosatu was doomed to fail "While that does not mean Cosatu has been cured of its problems, it does mean that Numsa and Vavi are well and truly out. (15 Jul. 2015 Daily Maverick)". This throws doubt on whether or not Cosatu will be able to retain the support that gave it dominance amongst labour, and this no doubt will weaken the ANC in the next election.

The editorial commentator Marrian (6 Nov. 2015, Business Day,) describes how Cosatu and Numsa aim to establish rival trade union federations. She says Cosatu in 1991 boasted a million members. In 2009 it set itself a target of 4-million, but had paid-up members of less than 2-million this year. (6 Nov. 2015, Business Day,)

She suggests Cosatu will face tough competition from the union it expelled. Numsa was expected to finalise its plans to form a new federation in November 2015. At the time of its expulsion, the union was Cosatu's largest affiliate with more than 300,000 members. 
Marian says the two trade union federations that Cosatu will talk to are the Federation of Unions of SA (Fedusa), which has mainly white collar members, and the National Council of Trade Unions (Nactu), which styles itself as left of the African National Congress (ANC) and Cosatu. It will pursue merger talks with the two federations in what it described as a "fractured labour space". The shootings, termed 'a massacre' at Marikana in August 2012, have the markings of a deep-seated betrayal of the working class. For at its heart is the intransigence of capital, the lengths to which the ANC was prepared to go to demonstrate its support for the mining houses, and the desperate struggle of workers against low pay and appalling conditions in the mining industry (Ashman \& Pons-Vignon 2015, 103). The ANC set up an emergency task team to bring about a settlement to the dispute at Marikana, which failed. "The ANC leadership could no longer draw upon layers of loyalty to the ANC, given AMCU's painful emergence out of NUM, especially in the wake of the Marikana massacre." (p. 105) It was envisaged there would be deep-reaching policy changes after the 2014 elections as a result of the shootings at Marikana. "These failed to eventuate and can only lead one to believe that the ANC must expect continuing deterioration in its popular support." (Alexander, 12 Dec 2012). It is extraordinary that there has been so little social commentary either in the media or by political parties, on the ANC government's role at Marikana, and little of what has been said, does not call for heads to roll or even for a public review, holding the ANC accountable. Little of political consequence for the ANC emerges from the Farlam Commission report.

Raymond Suttner, an ANC member and academic, writing five weeks after the Marikana shootings, describes the Tripartite Alliance:

At this moment, for the first time one can say without any sense of exaggeration that the ANC, South African Communist Party, Cosatu alliance, insofar as it exists, has no ideological coherence or significance and provides little political leadership and direction. It may exist as a name but it no longer captures the moral fervour that led millions to place their hopes in them. (Alexander, Peter, 2013.) 
Gentle. (17 Sept. 2013), writing for The Bullet) ${ }^{45}$ says at its deepest level, the underlying causes for the problems within Cosatu lie in the major structural changes that have happened to the working-class over the last 20 years and the re-alignment of Cosatu's membership as part of a growing middle-class. Over the past 20 years the ANC has faced ongoing censure from Cosatu and SACP over its embrace of neo-liberal economic policies.

This symbiotic relationship between Cosatu, the Communist Party and the ruling party has delivered since the 1994 dawn of democracy. Now that COSATU's legitimacy is in question, its erstwhile largest affiliate, NUM, is disgraced, alongside the SACP. And with this goes the legitimacy of the ANC itself. (Gentle. 17 Sept. 2013, The Bullet)

Gentle says the ANC now faces not only dislocation of its tripartite alliance, but the loss of its national leadership as a consequence. Both Cosatu and the ANC need to redeem their standing with the working class or face their own demise as millions of workers establish their own political party. Numsa's expulsion was due to its refusal to remain silent on controversial ANC policies, especially the privatisation of state services and the ANC's failure to end mass poverty in the country.

In conclusion, the shooting of workers at Marikana by the police will remain in the collective consciousness of South Africans for years to come. For the police to shoot striking workers was an appalling indictment of the post-apartheid liberation movement Igovernment of the ANC and its partners Cosatu and the SACP. If it were a premeditated massacre as is suggested then Marikana was a key turning point in the ANC's support of the working class and the labour movement. It was a crude betrayal of the collective values of the ANC Tripartite Alliance -- a 'defining moment' of change in the post-apartheid government.

I've never witnessed such a period of vibrant, explosive, but uncoordinated worker militancy.... Jacob Zuma's government is panicking about lost elite legitimacy, calling on October 17 for a pay freeze for top private sector, parastatal and state management to make a token gesture at addressing unemployment. (Bond, 18 Oct. 2012). 
Bond refers to how "the nine main mining firms recorded $\$ 4.5$ billion in 2011 profits from their SA operations. Not fooled any longer, workers are showing signs of ungovernability, moving by tens of thousands from NUM affiliation to the rival AMCU."No ideologues have yet posed a vision to rescue South Africa from intense pressures that seem to grow stronger each week. What is definitive, though, is the waning of any remaining illusions that the forces of 'liberation' led by the ANC will take South Africa to genuine freedom and a new society. Marikana will have that effect, permanently. (Bond, 18 Oct. 2012).

The attendant roles of the SACP, Cosatu and NUM fade away completely without explanation while the ANC's Deputy President, Cyril Ramaphosa, is an ambiguous central player both in the planning of police intervention of Lonmin workers, and what seems a self-interested role as a major shareholder of the mine.

Despite the heightened rhetoric, it is dramatic and a clear 'turning point' if not another 'defining moment' in the history of labour as Numsa takes the initiative by declaring its intention to found a new socialist movement after cutting its support of the ANC after Marikana and before the 2014 elections.(Alexander, 2013; Gentle 2014a, Part 1.)

Journalist Palesa Morudu, suggests the platinum strike and events at Marikana open up an opportunity to redefine the values of post-apartheid South Africa, suggesting this may be an opportunity to enable a new social contract between whites and blacks. (Business Day, 17 June 2014).Another perceptive commentary three years after the shootings, tells us:

Everything has changed but nothing has been solved. That South African landscape of gross inequality, which suffocates the growth and development aspirations of leaders and the led alike, will also still be here.(Hartford, 18 June, 2015, Business Day.) On 23 January 2014, workers at South Africa's major platinum producers - Anglo American Platinum, Impala Platinum, and Lonmin went on strike demanding that wages be immediately doubled. However, after five months of striking they settled for a more modest pay increase spread over three years. It was the longest and most expensive strike in South African history. (Reuters. June 13, 2014.and Andre Janse van Vuuren (June 18, 2014). 
That Hartford ${ }^{46}$ argues that after the longest and most costly strike in SA's century-old mining industry, leaders in government, business labour will have to face the reality that not much has changed. " In truth, a lot of things got a lot worse."

But, fundamentally, nothing much has changed. ....The strategic epicentre of the industry's future - its future growth path and wealth-sharing model - has not yet been grasped at all. (Hartford, 18 June, 2015, Business Day.)

The media focus on Cosatu's demise fails to implicate the consequences that will affect the ruling party politically. However Sharp's description of the rise of the black middle class ameliorates this to some degree, but leaves us wondering what the break with labour could mean politically for the ANC in future. This needs to be written about and should remain on the media's agenda. It remains to be seen what is likely to happen in the mining sector in particular in platinum mining after the conflict between NUM and AMCU.. There is no doubt that with the losses experienced by the leading platinum companies that the government has to engage with both the mining industry and labour leaders in a revision of labour law and negotiation practices.

\section{Conclusion}

I conclude that the analysis of what happened to the trade unions at Marikana and the impact on government is best documented by academic writers. A major failing by the press was not to follow the full flight of the strike and how it exploded into union battles with one another that resulted in violence that led to the police shootings. Cosatu's pandering to the ANC with the resultant emergence of Numsa in opposition to both, suggests a new period in which labour becomes more overtly political, with consequences for government. 


\section{CONCLUSION}

Marikana is a complex story of many dynamics. In making sense of it I discerned four main themes in the Marikana narrative, each of which is ongoing and evolving, with new findings that emerge over the months and years after the strike and the police shootings. There is an economic narrative that tells the story of mine owners using oldstyle exploitation of mineworkers, conflicts, strike action, and loss of production in the platinum sector which is a leading mining resource. The narrative leads us to explore the extreme inequalities that exist in the sector and to an ever-changing human interest story. What follows is a tribal narrative told by modern city newspapers that is clearly prejudiced in its lack of understanding of the social transformation of men who are one minute rural agriculturalists and the next, working as mercenaries with powerful machinery underground in the industrial mining context. To the modern world, they are men who carry with them traditional weapons, whom the police try repeatedly to disarm, and who take tribal medicine ('muti') to protect themselves.

The third narrative is of violence. It develops at the start of a week of the strike that include the brutal deaths of two policemen and two guards and six others, who are hacked to death. The anger and fear and need for revenge that this generated, resulted in the police shootings of 112 striking workers of whom 34 are killed. The fourth narrative reflects the fading lack of control of workers by unions and describes the transformation occurring in labour movements. This narrative clearly defines the threat to the ANC government and its labour federation Cosatu, as they increasingly lose working-class support to new union structures that threaten to develop socialist organisations opposed to the ANC. The strength of financial journalism in this narrative is most evident in the way it positions the strike in the relatively new platinum sector, of huge importance to the economy.

These four narratives continue to raise questions about the strengths and weaknesses of the media in South Africa. The focus of this thesis is on the press and press blogs and photo journalism, as well as a documentary film Miners Struck Down, as the most 
developed and articulate sections of the media. It also included the main findings of the Farlam Commission of Inquiry into the shootings that added to the detail in the narratives and raised questions for the media.

The main findings of the media narrative on the economy of mining operations at Marikana suggest firstly that although there have been attempts to modernize the mining sector and to rid it of the exploitative migrant labour system of the gold industry, not much has been achieved. Certainly the changes do not constitute what might be expected from the platinum industry, one of the most lucrative resources in the world. The mining sector continues to depend on cheap labour. There are changes in the way migrancy is handled, but they undermine the security of workers and do not provide permanent employment. A large part of the workforce is brought in on contracts.

It is now 20 years since the end of apartheid and birth of the new democratic South Africa. While the mining industry has done away with most of its mass housing of workers in single-sex hostels, one of the main blights in the mining industry, most workers now live in rural and peri-urban poverty, many having brought their families to the proximity of the mines. This lack of proper housing and services and their dehumanising working conditions, opens up the human interest story of employment in mining. What emerges in the economic narrative on the platinum industry is a description of the extreme inequality between mine owners, shareholders and their staff compared with the mine workers. South Africa experienced the biggest strike in its mining history with rolling strikes over 20 months culminating in a final 5 months of continuous strike action. The media reported that $40 \%$ of global platinum production was lost, a combined loss of Rand 24-billion (US\$2.25-billion) in lost revenue to Lonmin, Anglo-American Platinum and Impala Platinum. ${ }^{47}$

The financial press has been clear in its reporting of how important the platinum industry is to the South African economy. Where the South African press falls down is in its descriptions of social conditions and the human experience of transition from the rural home to shacks in the vicinity of the mine, not only for workers but for their families. The 
international press, investigating the Marikana after the fact, successfully tagged the human conditions that mining workers live under. .

The human interest narrative that did emerge in the South African media was one that describes the 'otherness' of the tribal practices with a clear prejudicial urban-rural and tribal-modern bias which became evident even from the ANC leaders who disparagingly referred to these practices as if they were relics of the past without respect for this diversity. This second narrative that emerges from the reportage is about how and why Zulu or Xhosa tribesmen (and others) carry their traditional weapons when on display together as workers and as members of trade unions. The main explanations from the tribesmen are that it is manly for men to carry weapons and it is a tradition from the days of Shaka Zulu -- the most revered warrior. Their transition from rural agricultural activities to those of industrialised underground workers using powerful pneumatic drills to chisel away at rock-faces as a rare skill in the resource rich economy dependent on it, is not reflected in the narratives of the media nor even by the social scientists examining Marikana. Yet, this incongruity became part of the main narrative in the way that the strikers carrying their simple rural weapons as explicit symbols above ground to demonstrate their physical prowess in a faceoff against the police armed with their own powerful automatic weapons. What is missing in virtually all the press narratives is some analysis of the skills that rock-drill operators (RDOs) have as the front line at the rock face in mining contrasted with the their conditions of work and level of pay and low level of benefits. Resource dependent economies ignore these realities as vital elements to reflect how the workforce is treated, and whether it gets its fair share of the wealth that is generated by platinum mining.

A range of media narratives of tribal herbalists treating the strikers with 'muti' (tribal medicine) as would-be warriors preparing for battle, was repeated by the police and the former Deputy President of the ANC, Kgalema Motlanthe, also a former general secretary of the NUM. All repeat, clearly prejudicially, that the 'muti' would protect the strikers from the weapons of their enemy, suggesting the 'backwardness' of the miners and the need for a shift from tribalism to modernity. 
It became clear in the narratives of the strike and build-up to the shootings on August 16,2012 , that the police demanded the strikers hand over their weapons on several occasions. The combination of strikers refusing to disarm and being told by a director of Lonmin, none other than the ANC's Deputy President, Cyril Ramaphosa, that their wildcat strike was illegal and the strikers were behaving in a criminal manner, and that the police should take action against them, was enough for the police to formulate its plan to engage a 'tactical team' to deal with the strikers by means of the shootings.

Several commentators ${ }^{48}$ concur that on 'D-Day' the ANC government sided with the mine owners against the workers' strike action at Lonmin in Marikana, and together they called on the police to act against the workers in what became a premeditated massacre. In the few days before the police shootings, the strikers killed ten people including two policemen and two Lonmin guards who were brutally hacked to death with machetes (pangas). The fear and anger this created determined the shootings as acts of revenge by the police. The main narrative reflects the description of the preparation for the shootings as a premeditated act by the police, aided by the platinum mining company Lonmin. The narratives demonstrate the conflation of roles between the state, Lonmin and the police resulting in the final shootings. City Press journalist Lucas Ledwaba commented in a book chapter in 2013 that there had been little open discussion reflected in the media narratives of alternative ways of seeking a negotiated way of resolving the impasse between the strikers and the company Lonmin. The refusal of Lonmin to meet strikers outside of NUM control is repeated again and again. The reporting of how the striking workers finally successfully reached a wage agreement with Lonmin a month after the shootings was well-reported detailing how outsider groups including an Anglican bishop were brought in to help the discussions., ${ }^{49}$ It suggested how NUM and the chief representative of traditional leaders, might have prevented the shootings, if they had been engaged earlier.

In sourcing information for this thesis I found the press coverage lacked sufficient details of the shootings, and were unable to provide a rationale behind the police action. Explanations of the factors that led to the shootings required this study to include 
reference to the findings of the Farlam Commission of Inquiry (June 2015) into the shootings as well as Desai's film Miners Shot Down (March 2014). Justification for the shootings given by the police, that they were attacked, was disproved Rehad Desai's documentary film Miners Shot Down, first released in March 2014. It is this documentary which provided a stark narrative that was picked up and turned into a legend what occurred on 'D-Day' It explicitly argued that the police action was finally based on fear and a need for revenge. Miners Shot Down is a film that was aired 18 months after the shooting on Al Jazeera, Reuters, YouTube ${ }^{50}$ and others. It shows in graphic detail the massacre of dozens of miners at Marikana. Although it is not clear how Desai managed to source police footage of the event, this footage "shows the miners being penned in by barbwire and mowed down by a fusillade," wrote Margaret Kimberley on the blog Global Research (4 June 2014,). In understanding the anger and fear that the police felt after finding their two colleagues hacked to death with machetes (pangas) three days before 'D-Day' (Chapter 3 p.3-4), should have suggested a moral incentive by the ANC to control the police carefully from that point onwards.

Soon after the shootings President Jacob Zuma, under public pressure, promised a commission of inquiry into the events. The Farlam Commission on the police shootings sat for 300 hours hearing evidence, and reported its findings three years after the shootings. It found that Ramaphosa was not "the cause of the massacre" and that such claims were groundless. It also said he played no role in the decision of the police to implement the "tactical option" that had resulted in the shootings on August 16. However, it does not critique his role in contacting the police and stigmatising the worker action as "illegal" and "criminal" in his email messages to the police.

The commission found that the "tactical option" taken by the police was defective in a number of ways. The decision to go ahead with a tactical option to "forcibly remove" the striking workers from the koppie if they refused to lay down their arms voluntarily and disperse, was taken by a national management team the evening before the shootings. It was also found that the police had misled the commission about when the decision was taken to use the "tactical option". Zuma said the original plan was to encircle the 
workers with barbed wire and offer them an exit point through which they would have moved while handling over their weapons. The Commission blamed Lieut.-Gen Mbombo and the police management team for taking the wrong decision on the day of the shootings. ( 26 June. 2012, IOL.) There had been no proper evaluation made of its plan of action, nor was it properly defined for the commission. The commission found that the police disclosure of evidence at the commission hearings was "characterised by lies and obstructionism".

The Commission found that the police action should have been stopped after the first shooting phase at Scene 1 when the first 17 strikers were killed. Instead it went ahead in the second shooting at Scene 2 where "there was a complete lack of command and control." Making sense of D-Day has been an ongoing challenge for the media. The investigations by four journalists, ${ }^{51}$ that took up to three years to describe the scene 2 shootings, suggested the strikers at this stage "posed no threat to the police and were executed by the police away from television cameras". They described how 295 rounds of ammunition were fired at hundreds of miners seeking refuge in the rocky area of scene 2 after witnessing the first shootings. Some put their hands in the air to signify surrender or that they were not attacking the police, "but were still shot." It was claimed in the hearings that the police had planted weapons on at least six of the dead. Pathologists who described in detail the injuries of the dead suggested how some individuals could have been saved if given medical attention in time. In concluding the theme of the 'D-Day' police shootings, Jack Shenker, (3 July, 2015) writing a commentary in The Guardian titled: The Marikana massacre report has brought no justice and no relief, states that "...only one thing was clear: the wait for truth and accountability continues." 52

The fourth narrative on the evolving nature of the transformation of the labour movement under the ANC, and the emergence of grassroots opposition as a fall-out from Marikana has been described as the fulcrum of the class struggle in South Africa (Martin Legassick, 2012)-- a defining moment in the relationship of the Alliance partners in government. The shootings were seen by the strikers and many trade unions as a 
betrayal of the working class, and the betrayal of the values that the leadership of the new government held after their liberation from apartheid. Cosatu's loss of relevance with labour, the Communist Party's loss of intellectual leadership and the ANC's loss of the working class as its power base, may well be a combination that could cost the ANC its commanding position. ${ }^{53}$ Three years after the shootings, the ANC has yet to be held accountable.

The dynamics of Marikana include the ANC's obvious preparedness to demonstrate its support for the mining companies. The National Union of Mineworkers (NUM), traditionally the most powerful trade union in the sector, failed to maintain its bargaining power as job insecurity and pay levels fell. NUM refused to support the strike, which then became a wildcat strike outside the routine negotiating methods used in labour regulation. At the same time, a new union with a more radical stance, the unaffiliated Association of Mineworkers and Construction Union (AMCU), positioned itself in the platinum mining sector to take over huge numbers of NUM members, while the central federation of unions the Congress of South African Trade Unions (Cosatu), part of the tripartite ANC government, lost its dominance and control. This was partly as a result of its expulsion of the National Union of Metalworkers of South Africa (Numsa), its largest affiliate with more than 300,000 members. Numsa's expulsion was due to its refusal to remain silent on controversial ANC policies, especially the privatisation of state services and the ANC's failure to end mass poverty in the country.

Cosatu and Numsa are now in competition with one another as rival trade union federations. Numsa in turn refused to endorse the ANC in the 2014 elections, and declared its intention to found a new socialist movement. This break was regarded as 'Numsa's Moment' and a turning point for South African labour and the working class, both seemingly abandoned by the ANC when it collaborated with Lonmin in trying to prevent the strike that then led to the police shootings. Commentators describe Cosatu as having the wrong politics in the transition to power by subscribing to the ANC's neoliberal market economy under the former State President, Thabo Mbeki who came under the influence of the World Bank, the International Monetary Fund and some of 
South Africa's largest corporations. In the current context of neoliberalism, there is a shift away from permanent employment, extensive labour casualisation through contracts with labour brokers and poor service delivery.

Zwelinzima Vavi, the former Cosatu general secretary, claimed labour brokering had led to the loss of 1-million private sector jobs in the period 1996-1999. The established trade unions were being forced to transform themselves. Union membership as a proportion of the national workforce was in decline from $45 \%$ in 1997 to $25.4 \%$ in 2014 . The working class was declining while the black middle class had been rapidly growing - from 1.8-million people in 1994 to 5.9 -million in $2014 .{ }^{54}$ In this process Cosatu had changed its composition from a largely blue-collar working class formation in 1980s and 1990 s to a largely public sector white-collar federation. In addition there was a generational change, with young people preferring to negotiate wages and working conditions individually.

The strike was initiated by rock-drill operators seeking to treble their wages from $\mathrm{R} 4,160$ (US\$500) a month to R12,500 (US\$1,500). Despite many having reached the decision to strike as trade unionists, most of the strike leaders then behaved independently of the unions, and took the main body of workers with them into strike action. Without the unions, strikers now saw themselves free of bureaucratic controls and ready to negotiate directly with their companies. Lonmin's total intransigence to meet the striking workers as the situation deteriorated, reflects how Lonmin failed as an employer to cope with its labour issues.

The narrative of Marikana is made up literally of hundreds of accounts of what happened and descriptions of many of the events and scenes in detail both by the media and by researchers; and before them, the voices of the participants: the mine workers, the Lonmin employees and directors, the police at every level, and those at the Farlam Commission of Inquiry, lawyers representing workers and their families and those representing the police and the company, and the commissioners themselves. In addition there was remarkable press photography of the striking workers day after day in every possible formation on the Rooikoppies (Red Hills) of Marikana. Also vital to the 
main findings of this thesis was the police video footage of the shootings which eventually made its way into a pivotal disclosure of events through the film Miners Shot Down 18 months after the event.

The narratives used in this thesis of Marikana are thus gleaned from the many sources. The press narratives used here do tell us the story of Marikana. Some of them give remarkable insight and detail into the social lives of strikers such as Mambush (the City Press team); others such as Business Day, Mail \& Guardian and Daily Maverick provide most of the main narrative while the foreign press such as The Guardian provide a fuller social and political context of the South African story. While the foreign press agencies and some of the blogs trying to break new ground, publish authoritative stories, these are sparse and too intermittent. In the critique of the Marikana media coverage this thesis identified that the principal problem in covering the strike and the shootings at Marikana was the lack of in-depth reporting and analysis of the mining economy and its labour. As discussed, and reflected in other commentaries, the media, save for intermittent exceptions from those mentioned, ${ }^{55}$ fail to provide in-depth reporting or proper investigative research. Secondly, it was the failure of the media to investigate and detail the social and political impact of the police shootings on the tripartite ruling partners in government. ${ }^{56}$ The ad hoc nature of the events that appeared to be informal and 'wildcat', but which were like a gathering storm that led to the fateful events of the shootings at Marikana, did not receive an adequate coverage and were overtaken by the gravity and impact of the events. Newsrooms across the country appeared to be unprepared, lacking beat reporting skills identifying a trend in the labour conflict and the impending clash between corporate and state apparatus. This is largely the result of insufficient newsroom resources such as beat reporters who are informed and expert with networks of sources in corporates, in communities, in trade unions, and on the ground. The third main critique of the press, identified best by Jane Duncan, was its failure to interview eye-witnesses or participants involved in the strike and the shootings in the days that these occurred -- both essential to the running of a proper news operation. The urban-rural divide might be the cause of such bias, but in a world where 
electronic communication and social media are ubiquitous, this divide reflects much more problematic communication challenges for urban reporters.

It has taken a full three years for much of the story to unfold, either through the ongoing work of the commission, the investigations by academics, and deeper investigative and reflective pieces by journalists. There is a need for journalism in South Africa to make better use of its methods of investigations by being better informed, especially in the social sciences. At Marikana this shift would have required the media at large to engage the state, the mining companies and the trade unions in how they might best address the lack of basic education and literacy of miners; the need to engage in such issues as 'resettlement' of families; and social participation in urban life and the building of communities with the attendant educational, welfare and health services. Marikana was a defining moment in South Africa's post-apartheid history, and will continue to draw on the conscience of a nation and the capabilities of the watchdogs of the nation, the media, as a service while society is grappling to integrate the social values of the new society. 


\section{APPENDIX 1:}

The Star Front Page on 17 August 2012

Reproduced with permission from the editor of The Star, Kevin Ritchie
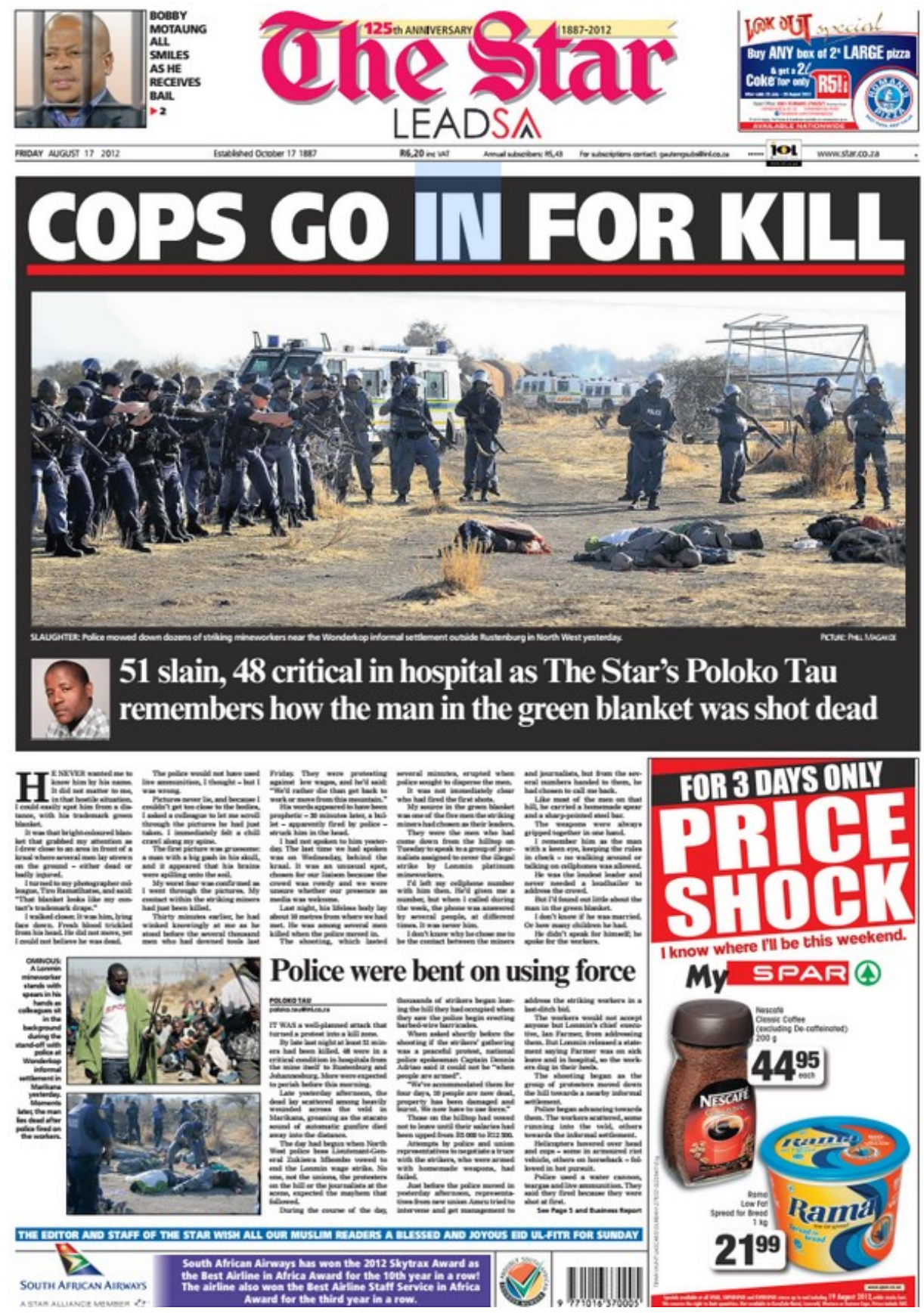


\section{APPENDIX 2: TABLE 1}

\section{Average Salaries of Miners - Source, International Labour Organisation and the Human Sciences Research Council, Johannesburg+}

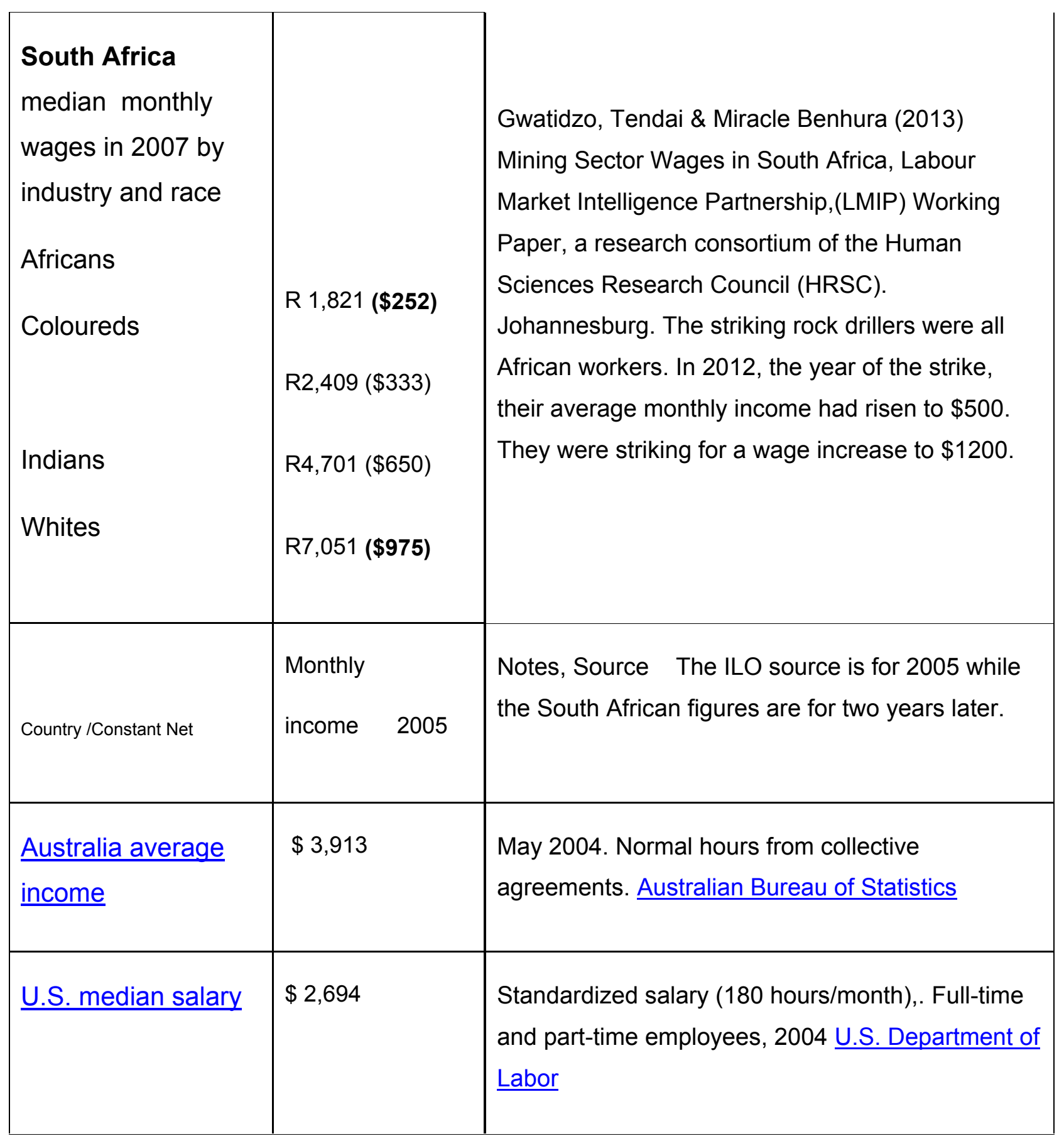




\begin{tabular}{|c|c|c|}
\hline $\begin{array}{l}\text { Canada average } \\
\text { income }\end{array}$ & $\$ 2,607$ & Employees, 2005. Statistics Canada \\
\hline UK median salary & $\$ 2,503$ & Employees, 2005. UK Employment Department \\
\hline $\begin{array}{l}\text { Germany average } \\
\text { salary }\end{array}$ & $\$ 2,223$ & $\begin{array}{l}\text { Other mining and quarrying industry. Minimum per } \\
\text { month, 2004, month. }\end{array}$ \\
\hline $\begin{array}{l}\text { Korea average } \\
\text { salary }\end{array}$ & $\$ 1,983$ & $\begin{array}{l}\text { Excl. overtime and bonus, June 2005. Korea } \\
\text { Ministry of Labour }\end{array}$ \\
\hline $\begin{array}{l}\text { Taiwan average } \\
\text { income }\end{array}$ & $\$ 1,709$ & $\begin{array}{l}\text { Full-time and part-time employees, } 2004 \text {. Other } \\
\text { mining and quarrying industry. National Statistics } \\
\text { Republic of China. }\end{array}$ \\
\hline $\begin{array}{l}\text { Finland average } \\
\text { salary }\end{array}$ & $\$ 1,678$ & $\begin{array}{l}\text { Other mining and quarrying industry. Normal hours } \\
\text { of work, } 2004 \text {. Men only. Women make } 1,836 \\
\text { Euros per month. Statistics Finland }\end{array}$ \\
\hline $\begin{array}{l}\text { Austria average } \\
\text { salary }\end{array}$ & $\$ 1,432$ & $\begin{array}{l}\text { Standardized average salary ( } 40 \text { hours/week), } \\
\text { employees, 2002. Austrian Central Statistical } \\
\text { Office (ÖSTAT) }\end{array}$ \\
\hline $\begin{array}{l}\text { Poland average } \\
\text { income }\end{array}$ & $\$ 1,295$ & Employees, 2004. Poland Central Statistical Office \\
\hline
\end{tabular}




\begin{tabular}{|c|c|c|}
\hline Italy average salary & $\$ 1,145$ & $\begin{array}{l}\text { Normal hours of work, 2005. Istituto Nazionale di } \\
\text { Statistica }\end{array}$ \\
\hline $\begin{array}{l}\text { Russia average } \\
\text { salary }\end{array}$ & $\$ 1,052$ & Employees, 2004. Federal State Statistics Office \\
\hline $\begin{array}{l}\text { Portugal average } \\
\text { salary }\end{array}$ & $\$ 942$ & $\begin{array}{l}\text { Other mining and quarrying industry. Employees, } \\
\text { 2003. Instituto Nacional de Estatística }\end{array}$ \\
\hline $\begin{array}{l}\text { Czech Republic } \\
\text { average income }\end{array}$ & \$935 & Excl. bonuses, 2005. Czech Statistical Office, \\
\hline $\begin{array}{l}\text { Slovakiaaverage } \\
\text { income }\end{array}$ & $\$ 929$ & $\begin{array}{l}\text { Employees, men, 2003. Štatistický úrad Slovenskej } \\
\text { republiky }\end{array}$ \\
\hline $\begin{array}{l}\text { Romania average } \\
\text { salary }\end{array}$ & $\$ 882$ & $\begin{array}{l}\text { Men employees, 2005. Romania National Institute } \\
\text { of Statistics }\end{array}$ \\
\hline $\begin{array}{l}\text { Latvia average } \\
\text { income }\end{array}$ & $\$ 877$ & $\begin{array}{l}\text { Adult full-time and part-time employees, } 2005 . \\
\underline{\text { Central Statistical Bureau }}\end{array}$ \\
\hline $\begin{array}{l}\text { Hungary average } \\
\text { salary }\end{array}$ & $\$ 812$ & $\begin{array}{l}\text { Employees, May 2005. Hungarian Central } \\
\text { Statistical Office }\end{array}$ \\
\hline $\begin{array}{l}\text { Lithuania average } \\
\text { salary }\end{array}$ & $\$ 797$ & $\begin{array}{l}\text { Employees, other mining and quarrying industry, } \\
2002 .\end{array}$ \\
\hline
\end{tabular}




\begin{tabular}{|c|c|c|}
\hline $\begin{array}{l}\text { Brazil average } \\
\text { income }\end{array}$ & $\$ 747$ & $\begin{array}{l}\text { Employees, 2001. Ministerio do Trabalho e da } \\
\text { Previdência Social }\end{array}$ \\
\hline $\begin{array}{l}\text { China average } \\
\text { salary }\end{array}$ & $\$ 620$ & $\begin{array}{l}\text { Employees, other mining and quarrying industry, } \\
\text { 2005. National Bureau of Statistics of China, }\end{array}$ \\
\hline $\begin{array}{l}\text { Mexico average } \\
\text { income }\end{array}$ & $\$ 584$ & Employees, 2003. Instituto Nacional de Estadística \\
\hline Peru average salary & $\$ 531$ & $\begin{array}{l}\text { Employees, June 2001. Men only. Instituto } \\
\text { Nacional de Estadística e Informatica }\end{array}$ \\
\hline $\begin{array}{l}\text { Kuwait average } \\
\text { salary }\end{array}$ & $\$ 491$ & $\begin{array}{l}\text { Other mining and quarrying industry, 2004. Kuwait } \\
\text { Ministry of Planning }\end{array}$ \\
\hline $\begin{array}{l}\text { Philippines average } \\
\text { salary }\end{array}$ & $\$ 440$ & Employees, 2004. National Statistics Office \\
\hline $\begin{array}{l}\text { Thailand average } \\
\text { salary }\end{array}$ & $\$ 306$ & $\begin{array}{l}\text { Men employees, } 2005 \text {. Women make } 3,945 \text { bahts } \\
\text { per month. Thailand National Statistical Office }\end{array}$ \\
\hline
\end{tabular}




\section{PRESS RESOURCES \& BIBLIOGRAPHY}

\section{South African Press Resources \\ SABC (South African Broadcasting Corporation)}

SABC interview with Lucas Ledwaba and Leon Sadiki of City Press authors of We Are Going To Kill Each Other Today": The Marikana Story

https://www.youtube.com/watch?v=oblhOLupBRc

\section{Beeld}

De Lange, Jan, Sake 24, Beeld, miningmx, Wed, 15 Aug 2012, " NUM no innocent victim in Lonmin violence." http://www.miningmx.com/opinion/columnists/NUM-no-innocentvictim-in-Lonmin-violence.htm

\section{Business Day}

Derby, Ron, (2012), "Lonmin Shootings will change SA labour relations", Business Day 17 August.

Friedman, Steven, (2015). "Can Union Movement Help Cure Our Economic Ills?" July 22.

Hartford, Gavin, (18 June 2015). " Everything has changed but nothing has been solved," Business Day \& BDlive.

Maoto, Monde and Natasha Marrian, (17 Aug. 2012) "Massacre' outrage as workers die in bloodbath at Marikana", Business Day.

http://www.bdlive.co.za/business/mining/2012/08/17/massacre-outrage-as-workers-die-in-bloodbathat-marikana

Marrian, Natasha, (6 Nov. 2015) " Cosatu, Numsa aim for rival federations", Business Day, BDLive. 
Marrian, Natasha, (July 17, 2015)."Congress Shows Zuma Palace Politics Rule Cosatu's Roost."

Marrian, Natasha, (July 14, 2015). "Disputes Again Mar Cosatu Congress,"

Marrian, Natasha, (July 16, 2015). "Veneer of Unity Will Soon Crack."

Marrian, Natasha, (July 3, 2015) "Ramaphosa's Not the Deliverance ANC, SA Anticipate."

Mkhize, Nomalanga, (2014) "ANC ignored cultural codes at Marikana", Department of History, Rhodes University, Business Day, 26 Aug. 2014.

https://www.ru.ac.za/history/historynews/ancignoredculturalcodesatmarikana.html

Morudu, Palesa, (17 June 2014) " Struggle for a better life has been declared," Business Day \& BDlive.

Ndzamela, Phakamisa, (17 June 2014)." Give workers a stake to help stabilise mining sector." Business Day \& BDlive.

Patron, Carol, (7 Sept. 2015) " Labour broking changes 'bled jobs'," http://www.bdlive.co.za/national/labour/2015/09/07/labour-broking-changes-bled-jobs

Paton, Carol, (31 Aug. 2012), "Marikana Strikers May have been in Muti-induced Trance," Business Day. http://www.bdlive.co.za/national/labour/2012/08/31/marikana-strikersmay-have-been-in-muti-induced-trance

Paton, Carol (14 June , 2012), " Mine unions' rivalry has been brewing under the surface", Business Day.

Pickworth, Evan, (16 Aug. 2012). "Mine Violence puts South Africa's structural flaws in the Spotlight Warns S\&P", Business Day/ BDlive.

http://www.bdlive.co.za/business/mining/2012/08/16/mine-violence-puts-south-africas-structuralflaws-in-the-spotlight-warns-sp

Seoka, J, (5 Sept. 2012) "Charges Against Miners Raise Questions," Business Day. 


\section{Economic \& Political Weekly, EPW}

Pillay, Suren, (December 14, 2013). "The Marikana Massacre: South Africa's PostApartheid Dissensus", Economic \& Political Weekly, EPW, December , vol xlviii No. 50.

\section{City Press}

Areff, Ahmed, (5 July 2015) "Alliance Summit silent on key issues--Vavi", City Press /News 24.

City Press, 2012, "Shabangu moves to reassure investors after a second ratings agency downgrade in three weeks", City Press, 13 Oct. 2012.

http://www.news24.com/Archives/City-Press/Minister-tells-ANC-to-drop-nationalisation-2012-10-13

City Press, (17 June 2013). "Marikana Cleansing Ceremony 'Successful'".

City Press, (30 Aug. 2012). "Mine unrest to hit investment --Shabangu ". http://www.news24.com/Archives/City-Press/Mine-unrest-to-hit-investment-20150430

Ledwaba, Lucas, (18 Aug. 2012), "The Guns of Marikana/ secret rituals" City Press.

Ledwaba, Lucas, (Aug. 2013) We Are Going To Kill Each Other Today: The Marikana Story Chapter 1, Guns and Spears: Setting the Stage.

Makinana, Andisiwe, (14 Aug. 2015)" Marikana: MPs call on state to compensate slain miners' families," City Press.

Mashego, Abram, and Saba, Athandiwe, and City Press Staff reporters, (6 April 2015)." South Africa - police commissioner Phiyega on the ropes over Marikana reports." http://africajournalismtheworld.com/2015/04/06/south-africa-police-commissioner-phiyega-on-theropes-over-marikana-reports/

Nhlabathi, Hlengiwe, (12 July 2015) "Cosatu was wrong to back Zuma - Dlamini", City Press/ Media 24.

Nhlabathi, Hlengiwe, (9 Jul.2015), "We won't entertain Vavi and Numsa issues Cosatu," City Press. 
Tau, Poloko, (13 Aug 2015)."Marikana: A newshound's account of the build-up to the massacre," City Press. http://www.news24.com/SouthAfrica/News/Marikana-A-newshoundsaccount-of-the-build-up-to-the-massacre-20150813

\section{Mail \& Guardian}

De Wet, Phillip, (18 Aug. 2012), "Malema at Marikana: 'Many will die'", Mail \& Guardian.

De Wet, P., (17 August [online],2012),"Zuma announces inquiry into Marikana shooting", from Mail \& Guardian, Available at www.mg.co.za [Accessed: 14 August 2013]

De Wet, Phillip, (17 Aug 2012) Lonmin's Burning: "Mthethwa says Over 30 Killed", SAPA, Mail \& Guardian,.

https://www.google.ca/\#q=LONMIN\%27S+BURNING:+MTHETHWA+SAYS+OVER+30+KILLED

De Wet. Phillip, (21 Sept 2012). " Marikana: How the wage war was won," Mail \& Guardian. http://mg.co.za/article/2012-09-21-00-marikana-how-the-wage-war-was-won

Evans, Sarah, (16 Sept. 2015). " New coalition plans march against corruption," Mail \& Guardian. http://mg.co.za/article/2015-09-16-new-coalition-plans-march-against-corruption

Forrest Kally, (13 Sept, 2013) " Marikana was not just about migrant labour", Mail \& Guardian. http://mg.co.za/article/2013-09-13-00-marikana-was-not-just-about-migrant-labour Harvey, Ebrahim, (2015). "ANC Can't Halt Inevitable Cosatu Split", Mail \& Guardian, 17 July 2015. http://mg.co.za/article/2015-07-17-anc-cant-halt-inevitable-cosatu-split

Janse van Vuuren, André \& Mike Cohen (13 Aug. 2015). “Job-cuts backlash pits mining CEOs against Zuma." Mail \& Guardian.

Letsoalo, Matuma and Qaanitah Hunter, (17 July, 2015). "Cosatu Show of Strength Isolates Zwelinzima Vavi" Mail \& Guardian.

Letsoalo, Matuma and Qaanitah Hunter, (14 Jul. 2015) "Gone, not forgotten, Vavi still divides Cosatu," Mail \& Guardian. 
Letsoalo, Matuma, (7 July, 2015). "SACP General Secretary Nzimande Wants Action against the Print Media.

Maromo, Jonisayi, (16 Jan, 2014). "Marikana: Miners were not aware of cops", Mail and Guardian (South Africa), 16 Jan. 2014 http://mg.co.za/article/2014-01-16-marikanaminers-were-not-aware-of-cops

Maromo, Jonisayi, (Oct 2, 2012). "Farlam Commission hears of events leading to Marikana shooting", SAPA in the Mail \& Guardian.

Mataboge, Mmanaledi, (17Jul. 2015). "State's new propaganda plan to hurt media budgets," Mail \& Guardian.

Gqirana, Thulani, (10 Sept. 2015) "Malema stands by Ramaphosa 'murderer' remarks," Mail \& Guardian.

Sharp, Loane , (2014)."Class war behind Cosatu-Numsa divide", Mail \& Guardian 21 Nov 2014 http://mg.co.za/article/2014-11-21-class-war-behind-cosatu-numsa-divide Sosibo, Kwanele, (12 Oct. 2012). "NUM Bleeds Both Workers and Lives", Mail \& Guardian. http://mg.co.za/article/2012-10-12-00-num-bleeds-workers-lives

Sosibo, Kwanele, (22 Oct., 2012), "NUM: Lethal force ahead of Marikana shootings was justified."Mail \& Guardian. http://mg.co.za/article/2012-10-22-lonmin-caused-problem-atmarikana-say-police

Sosibo, Kwanele and Verashni Pillay, (1 Jan 2015), "Left moves to seize the moment", Mail \&Guardian. http://mg.co.za/article/2014-12-31-left-moves-to-seize-the-moment

Suttner, Raymond, (27 Sept. 2013). "The tripartite alliance has sold its soul", Mail \& Guardian.

Swart, Heidi, (21 Sept, 2012)."Lonmin miners crack under pressure", Mail \& Guardian. http://mg.co.za/article/2012-09-21-00-lonmin-miners-crack-under-pressure 
Tiwana, Mandeep, (17 Aug, 2015). " Marikana massacre and neoliberal plunder," Mail \& Guardian. http://mg.co.za/article/2015-08-17-marikana-massacre-and-neoliberalplunder?utm source=Mail+\%26+Guardian\&utm medium=email\&utm campaign=Daily+newsletter\&utm term=http\%3A\%2F\%2Fmg.co.za\%2Farticle\%2F2015-08-17-marikana-massacre-and-neoliberal-plunder

Tolsi, Niren. (2015) "SAPS Rot Runs Deep in Marikana Cover-up", Mail \& Guardian. http://mg.co.za/article/2015-07-02-saps-rot-runs-deep-in-marikana-cover-up

Tolsi, Niren.( 22 Oct , 2012). "Miners killed like 'possessed vermin', says lawyer", Mail \& Guardian. http://mg.co.za/article/2012-10-22-miners-killed-like-possessed-vermin-says-lawyer/

Tolsi, Niren and Paul Botes, (25 June, 2015) "Marikana: The Blame Game", A special report for Mail \& Guardian. https://laura-7.atavist.com/mgmarikanablamegame.

https://www.google.ca/\#q=The+Blame+Game\%2C+Mail+\%26+Guardian+

\section{MiningMX}

De Lange, Jan, (2012), "SA's labour dispensation changed forever", miningmx, 29 Aug 2012. http://www.miningmx.com/opinion/columnists/SA-labour-dispensation-changed-forever.htm

\section{Mining Weekly}

Natasha Odendaal (17 August 2012). "Lonmin killings hurt SA as mining destination". Mining Weekly. Retrieved 18 August 2012.

\section{Moneyweb}

Rees, Malcolm, (August 16, 2012). "Lonmin death toll at 34, 78 injured." Moneyweb. http://www.moneyweb.co.za/archive/lonmin-death-toll-at-34-78-injured/

\section{News 24}

News24, (2012) Timeline of the Marikana Massacre 2012 - 2013, ,South African History Online. http://www.sahistory.org.za/article/timeline-marikana-massacre-2012-2013

\section{SABC (South African Broadcasting Corporation)}


Labuschagne, L. (2012), 'SANDF on standby in Marikana', from SABC News, 15 September, [online], Available at www.sabc.co.za [Accessed: 13 August]

\section{SAPA (South African Press Association)}

South African Press Association (SAPA) in IOL news, (11 Aug. 2012), " Four hurt in clash at mine," http://www.iol.co.za/news/crime-courts/four-hurt-in-clash-at-mine-

\subsection{8\#.VUpVDPIVhBC}

SAPA (August 17 2012)" Lonmin an example of exploitation" IOL, Business Report (The Star) http://www.iol.co.za/business/companies/lonmin-an-example-of-exploitation-

1.1365221\#.VdCs vIVhBe

Independent Online. (17 August 2012. Retrieved 18 August 2012.) "SACP calls for arrest of Amcu leaders", Sapa

Sapa, TimesLive, (17 August, 2012). "'I told them to leave... I pleaded, I pleaded': Amcu leader weeps".http://www.timeslive.co.za/local/2012/08/17/i-told-them-to-leave-ipleaded-i-pleaded-amcu-leader-weeps

The Times. South African Press Association. (17 August 2012). "Lonmin killings senseless: Nehawu". Archived from the original on 19 August 2012.

South African Press Association (SAPA), (17 Aug. 2012)."Lonmin an example of exploitation", Business Report. http://www.iol.co.za/business/companies/lonmin-an-example-ofexploitation-1.1365221\#.VUg6C IVhBe

Sapa, (20 Sept, 2012). "Fears over precedent set by Lonmin mining deal." http://mg.co.za/article/2012-09-20-lonmin-mining-deal-could-set-precedent

Sapa, (Jan 30, 2014)."Ramaphosa raised at Marikana inquiry," The Citizen.

\section{The Sowetan}

The Sowetan. Reuters. (17 August 2012)."Police boss says 34 miners killed in self defence." Archived from the original on 19 August 2012. Retrieved 19 August 2012 
Nhlabathi, Hlengiwe, (30 Jan, 2013). "Photos distress Marikana witness", Sowetan.

Nhlabathi, Hlengiwe, (13 Mar, 2013). "Even Zuma Carries an Assegai", Sowetan, 2013.

Nhlabathi, Hlengiwe, (21 Feb, 2013). " Police Rounded Us Up Before Shooting" Sowetan,.

Nhlabathi, Hlengiwe, (12 Mar 2013). " Body parts and blood make powerful Muthi", Sowetan.

Selebi, Mogomotsi, (2012), " Muthi murder accused claims police assaulted him," Sowetan, 15 Aug, 2012. Editorial: (Aug. 17 2012). " African Lives Cheap As Ever". Sowetan.

\section{Sunday Independent}

Schutte, Gillian, (5 July 2015). " What Marikana media coverage told us," Sunday Independent.

The Star

Stoddard, Ed (25 June 2014)." South Africa miners return to work after longest platinum strike," Reuters. http://www.reuters.com/article/2014/06/25/us-safrica-mining-

idUSKBNOFOODC20140625

Front page of The Star, via personal correspondence with the editor, Kevin Ritchie

\section{Foreign Online news and opinion websites}

\section{AllAfrica.com}

AllAfrica.com, (17 Aug. 2012)," South Africa: Zuma leaves SADC summit to visit mine.

Available at allafrica.com [Accessed: 13 August 2013]

\section{LINKS}

LINKS (2014) "South Africa: Ronnie Kasrils calls for 'no vote' for African National Congress." http://links.org.au/node/3814 


\title{
The Big Read
}

England, Andrew (April 1, 2014) "South African mining: Stuck in the past," The Big Read

\section{THE BULLET}

Gentle, Leonard, (2014a), Part 1: "The Demise of COSATU", South Africa and the Changing Politics of Labour," The Bullet, Socialist project, E-Bulletin No 1027, 27 August 2014a. http://www.socialistproject.ca/bullet/1027.php

Gentle, Leonard , (2014b) Part 2: "NUMSA and the Emergence of a New Movement". The Bullet, E-Bulletin No. 1028, 29 August 2014b.

http://www.socialistproject.ca/bullet/1028.ph

\begin{abstract}
AlJazeera
Mutasa, Haru, (2912, Sept. 2) "Can Zuma Survive Marikana?" AlJazeera.

http://blogs.aljazeera.com/blog/africa/can-zuma-survive-marikana

\section{Channel 4 News,}

Gilmore, Inigo, (2013)." Marikana survivors 'harassed' ahead of trial", 29

Jan. 2013. http://www.channel4.com/news/marikana-zuma-to-publish-south-african-massacrereport

Gilmore, Inigo, (June 25, 2015)."Police Tactics Defective" Channel 4 News

https://www.youtube.com/watch?v=t6quOIOFY7Q

eNCA,

"New Evidence Shows Marikana Miners Shot First." (20 August 2012)

\section{YouTube}

Desai, Rehad: The best MARIKANA documentary on YouTube: MINERS SHOT DOWN https://www.youtube.com/watch?v=ssPrxvgePsc
\end{abstract}


Miners Shot Down: Documentary about the 2012 Marikana massacre Directed by Rehad Desai and first shown on 1 October, 2014, World Socialist Web Site, and Published by the International Committee of the Fourth International (ICFI)

\section{http://www.wsws.org/en/articles/2014/10/01/amer-o01.html}

Press TV, (2 November 2012. Retrieved 23 February 2014)." Inequality root cause of strikes in South Africa: Analyst." http://www.presstv.com/detail/2012/11/02/270007/southafrica-strikes-tied-to-inequality/\#

Somaiya, Ravi, (2013). "Police Video of Shootings at South African Mine Raises Questions", 1 February, The Lede (NY Times)

The Lede (NYTimes)

The Lede Blog (NYTimes) (AUG. 16, 2012) " Video Shows South African Police Shooting Miners " Film, TV \& Video.

World.Times, Perry, A., (16 August, 2012)," South Africa's Police Open Fire on Striking Miners: The Video", Time World, 16 August [online], Available at world.time.com [Accessed: 14 August 2013]

Usayd Younis, Miners Shot Down captured online by Ceasefire magazine published by https://ceasefiremagazine.co.uk/its-unequal-country-world-rehad-desai-future-south-africa/

\section{Academic/research Sources}

Alexander, Peter, 2013. "Marikana, turning point in South African history", Review of African Political Economy, 2013, Vol. 40, No. 138, 605-619, http://dx.doi.org/10.1080/03056244.2013.860893

Alexander, Peter, Thapelo Lekgowa, Botsang Mmope, Luke Sinwell and Bongani Xezwi (Dec 12th, 2012). "It was a Massacre." Launch of Marikana a View from the Mountain and a Case to Answer, Jacana@BooksLIVE, Dec 122012.

http://jacana.bookslive.co.za/blog/2012/12/12/it-was-a-massacre-peter-alexander-launches-marikanaa-view-from-the-mountain-and-a-case-to-answer 
Ashman, Sam and Pons-Vignon, Nicolas. (2015) "NUMSA, the Working Class and Socialist Politics in South Africa." Socialist Register 2015, (2015), 93-113 http://www.nuvole.it/wp/8-numsa-the-working-class-and-socialist-politics-in-south-africa-2/

Bachevanova , Svetlana (2011). "Interview of Greg Marinovich" for FotoWitness, April 20, 2011 http://www.fotoevidence.com/greg-marinovich

Bell, Derek and Martin Kreickenbaum, 1 October 2014, Miners Shot Down:

Documentary on the 2012 Marikana Massacre, Published by the International Committee of the Fourth International (ICFI) http://www.wsws.org/en/articles/2014/10/01/amer-o01.html

Bond, Patrick, (October 18, 2012). " South Africa's political economy after the Marikana massacre." Links International Journal of Socialist Renewal. (Director of University of KwaZulu-Natal's Centre for Civil Society in Durban.) http://ccs.ukzn.ac.za/files/Bond\%20Marikana\%2018\%200ctober\%202012.pdf Campbell, Susan Schuster (1998). Called to Heal. Halfway House: Zebra Press. ISBN 1-86872-240-6 Chaskalson, Raphael, 2013. "Platinum, Politics and Popular Resistance: Changing patterns of worker organisation on South Africa's Bushveld Igneous Complex, 19942012". 2012"

(BA Honours Dissertation, University of Cape Town, 2013)

Cock, Jacklyn, (1996). "The Link between Security and Development: The problem of light weapons proliferation in Southern Africa," African Security Review, Volume 5, Issue 5, 1996, Department of Sociology, University of Witwatersrand.

Cronin, Jeremy, "What lies behind the current turmoil within COSATU? Umsebenzi XIII, 15, 27 November 2014, 7pp. http://www.sacp.org.za/main.php?ID=4560

Cumes, David (2004). Africa in my bones. Claremont: New Africa Books.ISBN0-86486556-2. 
Di Paola, Miriam, and Pons-Vignon, Nicolas, (2013). "Labour Market Restructuring in South Africa: Low Wages, High Insecurity." Review of African Political Economy, XL, 138 (December 2013), 628-638.

Duhaime, Lloyd, "Common Law Legal Definition." duhaime.org, Wikipedia.

Duncan, Jane, (2012). "Marikana and the problem of pack journalism", Rhodes University, Published by the SABC.

Duncan, Jane (2013). "South African journalism and the Marikana massacre: A case study of an editorial failure", The Political Economy of Communication, Vol 1. No 2 (2013), Rhodes University. http://www.polecom.org/index.php/polecom/article/view/22

Fogel, Benjamin, (2013)" South Africa: Pro-government faction attacks COSATU's Zwelinzima Vavi", April 12, 2013 --Amandla posted at Links International Journal of Socialist Renewal

Fogel, Ben, (2012) "Massacre: Media Complicity in Marikana Repression" Ceasefire, Nov. 5, 2012. https://ceasefiremagazine.co.uk/south-africa-marikana/

Fuentes, Frederico, (Aug 29, 2014). "Two Years On, Impact of Marikana Massacre Still Felt in South Africa."TeleSur, and Links, International Journal of Socialist Renewal. http://www.telesurtv.net/english/opinion/Two-Years-on-Impact-of-Marikana-Massacre-Still-Felt-inSouth-Africa-20140829-0066.html

Friedman, Steven,(2015)." Can union movement help to cure our economic ills?, " Business Day, 22 July. http://www.bdlive.co.za/opinion/columnists/2015/07/22/can-unionmovement-help-to-cure-our-economic-ills

Gentle, Leonard, (2014a), Part 1: "The Demise of COSATU", South Africa and the Changing Politics of Labour," The Bullet, Socialist project, E-Bulletin No 1027, 27 August 2014a. http://www.socialistproject.ca/bullet/1027.php

Gentle, Leonard , (2014b) Part 2: "NUMSA and the Emergence of a New Movement". E-Bulletin No. 1028, 29 August 2014b. http://www.socialistproject.ca/bullet/1028.php 
Gentle, Leonard. (17 Sept. 2013). "A Week in August in South Africa, " The Bullet. http://www.socialistproject.ca/bullet/879.php

Gwatidzo, Tendai \& Miracle Benhura (2013) Mining Sector Wages in South Africa, Labour Market Intelligence Partnership,(LMIP) Working Paper, a research consortium of the Human Sciences Research Council (HRSC). Johannesburg.

Gumede, William Mervin (2005, 2007). Thabo Mbeki and the Battle for the Soul of the ANC, Zebra Press, Cape Town.

Hartford, Gavin, (18 June 2015). "Everything has changed but nothing has been solved," Business Day \& BDlive.

Hattingh, Shawn, (2014) "The Platinum Strike, BEE and the Future of Worker Struggles,"

The South African Civil Society Information Service, June 22014. http://sacsis.org.za/site/article/2022

History Online, "Eyewitness accounts of the Sharpeville massacre 1960," SHARPEVILLE: a Turning Point in South African History, South African History Online, 21 March, 1960. http://www.sahistory.org.za/eyewitness-accounts-sharpeville-massacre-1960 Janse van Vuuren, Andre (June 18, 2014). "Platinum Strike Deal Said to Be Delayed on Union Demands". Bloomberg.

Kimber, Charlie, (2014). "South Africa: from Marikana to the 'Numsa moment"' International Socialism. http://isj.org.uk/south-africa-from-marikana-to-the-numsa-moment/

Kimberley, Margaret , (4 June 2014), Commentary on Miners Shot Down, the documentary film by Rashid Desai, for Global Research.

Kothari, Ammina (2010). "The Framing of the Darfur Conflict in the New York Times: 2003-2006".Journalism Studies. Vol 11, No 2, 2010, 209-224. 
Laburn-Peart, Catherine, 1995. "Housing as a locus of power." in Crossing Boundaries: Mine Migrancy in a Democratic South Africa, Eds. Crush, Jonathan \& Wilmot James, IDASA, Cape Town, 1995.

Legassick, Martin, 2012. "The Marikana Massacre: A Turning Point?" The Bullet, Socialist Project, E-Bulletin No. 689, August 31, 2012.

www.socialistproject.ca/bullet/689.php

Lodge, Tom, 2011. "Sharpeville and Memory", Violence, memory and Commemoration: Perspectives from Southern, East and Central Africa. Birbeck College, 9th December 2011 University of Limerick.

https://www.gold.ac.uk/media/Lodge Sharpeville\%20and\%20Memory Nov2011.pdf

Mkhize, Nomalanga, (2014) "ANC ignored cultural codes at Marikana", Department of History, Rhodes University, Business Day, 26 Aug. 2014.

https://www.ru.ac.za/history/historynews/ancignoredculturalcodesatmarikana.html

Moodie, Dunbar, T. \& Vivienne Ndatshe, 1994. Going for Gold: Men, Mines, and Migration. University of California Press, Berkeley.

Nhlabathi, Hlengiwe, (2015) "Cosatu was wrong to back Zuma - Dlamini", City Press/ Media 24, 12 July 2015.

Nieuwoudt, Hermann, 2009. "Unprotected Strikes: Remedies Available to Employers." http://www.nortonrosefulbright.com/knowledge/publications/43454/unprotected-strikes-remediesavailable-to-employers

Nkosi, Lolah, (2014) "Social Impact of Mining," University of Johannesburg. https://152.106.6.200/bitstream/handle/10210/13886/Nkosi Lolah LLM 2014.pdf?sequence=1\&isAllo $\underline{w e d}=\mathbf{y}$

Pickworth, Evan, (2012). "Mine Violence puts South Africa's structural flaws in the Spotlight Warns S\&P", Business Day/ BDlive, 16 Aug. 2012 
Pons-Vignon, Nicholas, and Anseeuw, Ward, (2009). "Great Expectations: Working Conditions in South Africa since the End of Apartheid," Journal of Southern African Studies, XXXV, 4 (Nov. 2009), 883-899.

Pillay, Suren, (2013). "The Marikana Massacre: South Africa's Post-Apartheid Dissensus", Economic \& Political Weekly, EPW, December 14, 2013 vol xlviii no 50.

Rees, S.D. \& J.Ballinger (2001). "The Roots of a Sociology of News: Remembering Mr Gates and Social Control in the Newsroom", Journalism and Mass Communications Quarterly 78: 641-58.

Riessman, Catherine, Kohler, (1993)."Narrative Analysis," Sage, Qualitative Research Methods Series 30 .

Scanlan, Chip (2002), "Beat Reporting: What does it take to be the best?" Poynter Institute. http://www.poynter.org/news/media-innovation/5229/beat-reporting-what-does-it-take-tobe-the-best/

Schudson, Michael, (2003). The Sociology of News, 2nd Ed., W.W. Norton \& Co. NY. Segal, Nick \& Stephan Malherbe, (2014), Graduate School of Business, University of Cape Town for the Chamber of Mines, South Africa. Quarterly Labour Force Survey, Quarter 2, 2014.

Shenker, Jack, (2015)." The Marikana massacre report has brought no justice and no relief." The Guardian, July 3, 2015.

Shoemaker, Pamela J.; Vos, Tim P. (2009). Gatekeeping Theory. New York: Routledge. ISBN 0415981395

Sinwell Luke,(2015)." Autonomous Worker Committees in Marikana, South Africa: Journey to the Mountain", Johannesburg University.

South African History Online, accessed on 23 February (2015) http://www.sahistory.org.za/article/1973-durban-strikes 


\section{http://www.sahistory.org.za/article/association-mineworkers-and-construction-union-amcu}

Stillwell, L.C. (2004). Platinum in the South African economy. International Platinum

Conference 'Platinum Adding Value', The South African Institute of Mining and Metallurgy, 2004.é

Surju, Jay (31 Aug. 2912). Network for Pan-Afrikan Solidarity (Toronto). https://www.facebook.com/permalink.php?story fbid=494896423871878\&id=132641920163259

Thapelo, Lekgowa, Botsang Mmope and Peter Alexander, (21Aug. 2012). " How police planned and carried out the massacre at Marikana," University of Johannesburg, Socialist Worker, Issue No. 2317

Vavi, Zwilinzama, (2014) "The root causes of the crisis in COSATU?" Speech to mark the 40th Anniversary of the South African Labour Bulletin. Links International Journal of Socialist Renewal, 21 November 2014, 7pp. http://links.org.au/node/4165

Wikipedia Marikana References, retrieved (May 19, 2015).

Williams, John J. (2004), Towards a critical research methodology in journalism: Interrogating methodological assumptions, Ecquid Novi ISSN 0256-0054 2004 25(2):257-293

Wroblewski, Luke, (2003) ${ }^{57}$ "Visible Narratives: Understanding Visual Organization," http://www.lukew.com/ff/entry.asp?981

Zelizer, Barbie,(2011). "Journalism in the Service of Communication", Journal of Communication, No 61 (2011) 1-21 @ 2011). International Communication Association. ISSN 0021-9916 "Journalism in the Service of Communication" Annenberg School for Communication, University of Pennsylvania, Philadelphia, PA 19104, USA

Zelizer, Barbie (1993). "Journalists as Interpretive Communities", Critical Studies in Mass Communications, 10 (1993), 219-237.

\section{Press Statements}


Abahlali base Mjondolo Press Statement, (06 May 2014) " The ANC Must be removed from Office." http://links.org.au/node/3814

Full list and biographies of all the striking workers killed on 13 and 16, Aug. 2012

Based on the presentations made by the families of the deceased miners before the Marikana Commission of Inquiry on 14 and 15 August 2014. Published by SERI (SocioEconomic Rights Institute.) http://seri-sa.org/images/Deceased Miners Marikana Nov14.pdf 


\section{END NOTES}

${ }^{1}$ Protected Strike

There is a distinction between strikes that comply with the labour legislation (Labour Relations Act of 1995) and those that don't. In a protected strike "a striker is protected from any civil action an employer may wish to institute and may be dismissed for striking. An unprotected strike constitutes a breach of contract for which employees can be dismissed, interdicted or sued for compensation by the employer." (Nieuwoudt, Hermann, 2009)

\section{Pass Laws}

The Pass laws were introduced by the National Party as the backbone to the system of racial control known as 'apartheid'. It was a policy for separating people according to a system of racial classification. The pass laws controlled the movement and employment of all black people; determining where they should live in separate areas with separate schools, hospitals, welfare and transport. All indigenous black people were forced to carry "reference books" of identity papers that provided information on their African tribal descent.

${ }^{3}$ Best of the press

Business Day, Mail and Guardian, The Daily Maverick (online), City Press, The Guardian, and The Star.

\section{${ }^{4}$ Farlam Commission}

The report of the commission was released by President Zuma on June 25, close to three months after the commission provided its report to government March 31, 2015, much to the irritation of the lawyers that represented the families of those killed in the event.

\section{${ }^{5}$ Miners Shot Down}

Rehad Desai's film was awarded an Emmy by the Television Academy Foundation on 25 November 2015 (weeks before this thesis was completed).

${ }^{6}$ Rehad Desai comes from a family steeped in the struggle against apartheid, and when interviewed after the Emmy Awards said the film aimed to bring to the notice of the public the massacre as well as ongoing social injustices in the democratic South Africa.

${ }^{8}$ What Is A Blog?

BlogPress tells us that a blog is a type of website. "A website is really anyplace you can visit online with a URL / Domain (http://theblogpress.com) and allows you to view content." And we are told "Everything on the internet is a website! A Blog is a website where a writer or group of writers chronologically publish a variety of content including, but not limited to, opinions, commentary, stories, reviews, recipes, and current events. Blogs are managed using a content management system (CMS) which is simply a set of tools and code designed to allow you to easily add, remove, and edit your online content."

WordPress is a CMS content management system). "In short, you don't have to know how to write any code to have your own blog/website says BlogPress. 
http://theblogpress.com/what-is-ablog/?gclid=CjOKEQiAIO20BRCcieCSncPIqqMBEiQAOZGMnPEXi85hyuzFIkEQCxxauT5XGFzWla1uy0O aZbAT7MgaAkvJ8P8HAQ

9 "ANC ignored cultural codes at Marikana"

${ }^{10}$ Marinovich, Greg (Aug 17, 2012) Daily Maverick

11 The Star of 17, August 2012: Front page but a.

12 In 2009, coal became the largest component of South Africa's mining industry by sales value, with total sales of R65.4-billion (US\$8.1-billion ), followed by platinum group metals at R58-billion (US\$7.2-billion), and gold at R49-billion (US\$6 billion), - the top three minerals accounting for $71.2 \%$ of total mineral sales. Most commodity prices declined in 2009 due to the impact of the global financial crisis, which led to production declines for most minerals, resulting in the value of South African mineral sales falling by $19.6 \%$ to R241.3-billion (US\$29.8-billion).(21st General Meeting of the International Mineralogical Association from 1 - 5 September 2014 at the Sandton Convention centre in the Gauteng province.) Platinum: The six platinum group metals (PGMs) - platinum, palladium, rhodium, osmium, ruthenium and iridium - occur together in nature alongside nickel and copper. Platinum, palladium and rhodium, the most economically significant of the PGMs, are found in the largest quantities. The remaining PGMs are produced as co-products. South Africa is the world's leading platinum and rhodium producer, and the second largest palladium producer after Russia. South Africa's production is sourced entirely from the Bushveld Complex, the largest known PGM-resource in the world. Platinum is primarily used in the jewellery and automotive industries. Autocatalytic converters together with cleaner fuels, contribute to a $98 \%$ reduction in vehicle emissions. More than half of all the cars on the roads around the world and more than $90 \%$ of new vehicles are fitted with autocatalytic convertors. Today, demand for PGMs from the automotive industry is significant and growing, underpinned by ever-more stringent legislation in the USA and Europe and burgeoning auto markets in China and India. A major source of demand, for platinum and especially palladium, is in dental applications. These metals are combined with gold and silver to produce alloys suitable for dental inlays, crowns and bridges. Platinum with its associated elements are used as catalysts in a range of chemical reactions used in industry such as the cracking of petroleum products. Platinum agents continue to be the main chemotherapeutic agents used in the firstline and second-line treatments of cancer patients (Jan Rijn Zeevaart, 2013); It is a vital component of most electrical devises. (IMPLATS Annual Report 2005. http://www.implats.co.za/im/files/ar/2005/introduction/pgm applications.htm)

${ }^{14}$ See Appendix 2: Table 1

15 In gold mining, employment changed as more than 300,000 jobs were lost between 1986 and 1998 from 517,000 employees to 217,000. (Segal \& Stephan Malherbe, 2000.)

${ }^{16}$ The S\&P Index is a risk index based on market capitalizations of 500 large companies having common stock listed on the New York Stock Exchange or NASDAQ, a stock market index of more than 5000 common stocks and securities.

${ }^{17}$ Moody's provides investors with a simple system of gradation by which future relative credit worthiness of securities may be gauged.

134

18 http://www.bench-marks.org.za/research/rustenburg_review_policy_gap_final_aug_2012.pdf

${ }^{19}$ Outsourcing or sub-contracting labour: Neoliberalism is described as a strategy of capital to respond to the crisis of over-production and over-accumulation that threatened profitability from the late 
1960s and early 1970s. In its restructuring of social relations neoliberalism ensured fundamental changes in the labour process, from millions of workers being driven out of the labour process itself into unemployment, to a variety of forms of externalization and labour flexibility, part-time work, home work, casualization and outsourcing.

(Gentel, 2012, Part 1

20 The Bench Marks Foundation is an independent, 'faith-based' organisation monitoring how well companies perform in the field of social responsibility.

${ }^{21}$ R1.2-billion in financial flows to Bermuda?

In a question and answer session between the Mail \& Guardian and Lonmin, recorded by Lonmin on 10 October 2014, Dick Forslund in his Question 33, calculated that had Lonmin not paid R1.2b to Bermuda from 2008 to 2012 (a structure he says should have been collapsed as it did not appear to be a substantial commercial transaction), R3500-R4000 could have been added to the (rock-drill operator's) RDO wage.

Answer: No such payments were made to Bermuda during this period.

Question 34: He (Forslund) argues further that, also cutting down the management cost, as described above, would have freed up enough money that the RDO wage demand of R12,500 net in hand could have been met. Please comment.

A: It is generally accepted by all legitimate informed commentators and analysts that the 2012 RDO wage demand of R12,500 was unaffordable, and would have led to the decimation of the South African Platinum mining industry.

Dick Forslund author of The Bermuda Connection, is a senior economist at the Alternative Information and Development Centre (AIDC)

https://www.lonmin.com/downloads/QA Allegations of Tax Evasion Lonmin Plc 101014 FI NAL 3.pdf

22 Two contractors were appointed by the provincial government to build 12 blocks of Community Residential Units (CRU) and 292 Breaking New Ground (BNG) houses at Marikana Ext 2. Minister ZoeKota said of the work done thus far. "It is very impressive. It is of good quality and high class. This is one of the most remarkable housing projects the department has embarked on to revitalize mining towns. We can't wait to come and hand over the project." Currently CRU's in the form of six blocks of flats have been completed and are ready for occupation. The other six blocks will be completed by the end of December. The CRU's will house 252 families. 292 BNG's are expected to be completed by the end of January 2016. Currently Eskom is busy connecting electricity to the project. North West Human Settlements, Safety and Liaison. http://www.gov.za/speeches/north-west-human-settlements-marikana-housingproject-7-dec-2015-0000

${ }^{23}$ The Mail and Guardian described how the prospect of massive lay-offs prompted a resolution to the strike action. Their investigative reporting required interaction with the mediators, the strikers, the disaffected unions as well as the companies.

${ }^{24}$ The Commission for Conciliation, Mediation and Arbitration (CCMA) is an independent dispute resolution body established in terms of the Labour Relations Act, 66 of 1995 (LRA)

25 Operation Phakisa is derived from Malaysia's Big Fast Results Methodology that was used successfully to achieve rapid economic transformation. It also forms part of our Nine Point Plan to reignite growth and boost job creation, as announced in the13t5te of the Nation Address in 2014). (South African Government Aug 13, 2015)http://www.gov.za/speeches/president-jacob-zuma-report-operationphakisa-implementation-13-aug-2015-0000 
${ }^{26}$ In the Kwa-Zulu Natal violence of 1980s, it was argued that it was in the apartheid state's interest to have their homegrown Zulu leadership up against the revolutionary ANC and its fellow travelers (clearly also Zulus, but mostly urban-based). Such ongoing conflict was simply described by the white authorities as "black-on-black violence", and useful to them politically. The ANC 's position was to reject tribal linkages which they said had been exploited by the colonialists in Africa. When the ANC came to government it diminished the tribal chief systems of the 'homeland governments', replacing them with regional committees and/or municipalities, giving the tribal chiefs with lineage only ex-officio status in the boards of these.

${ }^{27}$ AlJazeera: http://www.aljazeera.com/news/africa/2012/08/201281754353971991.html

The Lede, New York Times blog: http://thelede.blogs.nytimes.com/2012/08/16/video-of-miners-shotby-south-african-police/? $r=0$

(eNCA ) eNCA and SABC:

https://www.youtube.com/watch?v=t6guOlOFY7Q

(eNCA + SABC Digital News) Reuters + IOL Thursday, August 16, 2012 available

on Reuters.com, video, mobile, and interactive television platforms.

${ }^{29}$ Lolah Nkosi, described the disruption of traditional family life as a result of single parenting due to unwanted and teenage pregnancies that arise from women having relationships with contract migrant workers who return home and leave the women and children in the mining communities behind; and as a result of premature death caused by HIV and related diseases that leave a dramatic number of orphans. She cited the International Institute for Environment and Development:

One of the most significant impacts of mining is migration of people into the mining area, particularly in the developing areas where mining is the most important economic activity....The International Finance Corporation says they migrate to the mining area because of the perceived opportunities rather than any guarantee of a job.

(Nkosi, 2014, p. 27)

30 The Philadelphia Inquirer founded in 1829 is today the third oldest daily in the United States. It began as a supporter of the Democrats but became a Republican newspaper changing hands several times most recently as part of the Knight Ridder group but sold repeatedly after that. Under James Elverson in 1900 it was regarded as the Republican Bible. (Williams, Edgar, 2003).

31 SAPA (South African Press Association) is the national news agency, while Reuters based in the US is a worldwide news agency.

32 Ledwaba writes in We Are Going To Kill Each Other Today: The Marikana Story. see picture of Mambush: http://www.amazon.ca/going-kill-each-other-today-ebook/dp/B00EHFAU1S

34 Greg Marinovich was one of a team of photographers that were active in the townships in South Africa between 1990 and 1994 during successive State's of Emergency, where there were restrictions on the media in reporting on the violence, especially apartheid state-initiated violence also called black-on-black violence. This group of photojournalists came to be known as the Bang Bang Club, and a movie about the group premiered at the Toronto International Film Festival in 2010.

35 The National Prosecuting Authority (NPA), was created in Act 108 in the 1996 Constitution, with the power to institute criminal proceedings on behalf of the State.

136

36 The Daily Maverick is an independent internet newspaper providing news, information, analysis and opinion from its newsroom in Johannesburg. 
37 Chair in Social Change and professor of Sociology at the University of Johannesburg,

38 SWAT -- "Special Weapons and Tactics" initiated by the Los Angeles Police in the late 1960 s.

39 The Mineral Energy Complex (MEC) is made up of mines, mineral processing and electricity and steel parastatals,

${ }^{40}$ http://www.nuvole.it/wp/8-numsa-the-working-class-and-socialist-politics-in-south-africa-2/

${ }^{41}$ The ANC web page defines itself as South Africa's liberation movement. http://www.anc.org.za/show.php?id=206

It defines that liberation was a result of mass insurrection across the country during 1985 and 1986 when the mass struggles of workers and residents of the townships in towns and cities began to support the armed struggle. It details the history of those struggles and the roles played by its Defiance Campaign the South African Communist Party, the Congress movement and Soweto revolt, and the growth of trade unions in labour, including the 1987 strike by 300,000 mineworkers.

42 Reference to the Brazilian president Lula da Silva who dramatically lifted 30 million people out of poverty and created 15 million jobs (Jay Naidoo, in the Daily Maverick, Nov 23, 2012.)

43 Ostensibly Vavi's suspension was for an indiscretion with a female staff member in Cosatu, but various commentators reflected it as a rightwing move to keep him out of action in his ongoing critique of the ANC.

${ }^{44}$ As a labour correspondent on the Rand Daily Mail, I observed the progress of the 'new' black unions in South Africa throughout the 1970s, I can attest to how slow and difficult it was for unions and their federations to become successful and powerful in a complex capitalist environment in which race and class interests dominated every situation.

45 http://www.socialistproject.ca/bullet/879.php

46 Hartford is an industrial sociologist and mining labour analyst

47. Lolah Nkosi, (2014) writing on the Social Impact of Mining, says the experience at Marikana demonstrates how the negative impact of mining activities can lead to social unrest, demonstrations, strikes "and damage the good will of the company and ultimately the reputation of the country as a preferred investment areas for mining activities."

(Nkosi, 2014, p.53.) She finds the failure of mining companies to improve living conditions and the failure of government to enforce corporate social responsibility programmes may well lead to more long lasting and dysfunctional strikes in the mining industry as happened at Marikana. (What happened in this period as a result of the strike and the police shootings, was a breakdown in the labour system with rising unemployment, and companies threatening the closure of mines and planning of large-scale lay-offs of tens of thousands of workers.)

48 Alexander (2012, 2013), Legassick (2012) and Gentel (2014 a \& b) as well as journalists Marinovich (2012), Sacks (2012), Fogel (2012) and human rights lawyer, Nichol (2013)

(Chapter 3, p.10)

49 Anglican Bishop Jo Seoka, is also chairperson of the Bench Marks Foundation, that has conducted annual research on the mining sector and its workers at Marikana. He said the police shootings could have been avoided if Lonmin had listened to the worker grievances. 
$50 \mathrm{https}: / /$ www.youtube.com/watch?v=fTSHk2LTdtw (last retrieved 1 Dec 2015)

51 Niren Tolsi, and Paul Botes, (25 June, 2015) "The Blame Game" in the Mail \& Guardian; Nicholson, Greg (June 2015). "Marikana report: Key findings and recommendations," Daily Maverick; and Marinovich, Greg, (2015). "The Cold Murder Fields of Marikana" Daily Maverick, ( 30 Aug. 2015.)

52 Jack Shenker, (3 July, 2015) : "No one has ever claimed responsibility for the Marikana massacre, even though several of the shootings were captured in real-time television cameras."

53 Gentle, Leonard , (2014b) Part 2.

54 These remarkable changes were partly due to the Black Economic Empowerment (BEE) policy in the private and public sectors, where there was large-scale employment of blacks at every level. (Sharp 2014).

${ }^{55}$ Business Day, Mail \& Guardian, Daily Maverick, City Press, and The Guardian.

${ }^{56}$ The tripartite alliance consists of the African National Congress (ANC, the Congress of South African Trade Unions (Cosatu) and the South African Communist Party (SACP).

${ }^{57} \mathrm{~A}$ Product Director at Google. Earlier he was the CEO and Co-founder of Polar, acquired by Google in 2014. 